\title{
Double Diastereoselective Acetate Aldol Reactions with Chiral $N$-Acetyl Thiazolidinethione Reagents
}

\author{
Tarek Sammakia* and Yingchao Zhang \\ Department of Chemistry, University of Colorado, Boulder, Colorado 80309-0215 \\ Supporting Information
}

Table of Contents:

S1 General Information

S2-S3 Synthesis of aldehyde 3

S4-S6 Synthesis of aldehyde 5

S6-S8 Synthesis of aldehyde 6

S8 General aldol procedure

S9-S12 Compound characterization of the products of Table 1

S13-S56 $\quad{ }^{1} \mathrm{H}$ and ${ }^{13} \mathrm{C}$ NMR spectra for all new compounds

General Information. All air or moisture sensitive reactions were conducted in ovendried glassware under a dry nitrogen atmosphere. Dichlorophenylborane $(97 \%)$ was distilled then stored in a resealable container bearing a Teflon valve at $-26{ }^{\circ} \mathrm{C}$ under a nitrogen atmosphere. (-)-Sparteine was distilled under high vacuum and stored under a nitrogen atmosphere at $-26{ }^{\circ} \mathrm{C} . \mathrm{CH}_{2} \mathrm{Cl}_{2}$, triethylamine, and 2,6-lutidine were distilled from $\mathrm{CaH}_{2}$ under nitrogen. THF was distilled from Na benzophenone ketyl under nitrogen. All other starting materials were used as received. Aldehyde 4 was synthesized by the procedure of Curran. ${ }^{1}$ Flash chromatography of the thiazolidinethione aldol adducts was performed on neutral silica gel (Mallinckrodt Silicar Silica Gel 150, 60-200 mesh (75-250 micron)) following the procedure of Still. $^{2}$ All other flash chromatography was performed using $60 \AA$ silica gel (32-63 micron). Flash chromatography of the thiazolidinethione aldol adducts on this silica or other "ordinary" silica gel (i.e., silica gel with a $\mathrm{pH}$ other than 7.0) led to partial cleavage of the thiazolidinethione auxiliary. ${ }^{1} \mathrm{H}$ NMR spectra were recorded at $500 \mathrm{MHz}$ or $400 \mathrm{MHz}$ as indicated in $\mathrm{CDCl}_{3}$ and were referenced to residual $\mathrm{CHCl}_{3}$ at $7.24 \mathrm{ppm} .{ }^{13} \mathrm{C}$ NMR spectra were obtained at $100 \mathrm{MHz}$ in $\mathrm{CDCl}_{3}$ and were referenced to the center line of solvent at $77.23 \mathrm{ppm}$. Infrared spectra were recorded as thin films on $\mathrm{NaCl}$ plates. Optical rotations were determined on a digital polarimeter at $27{ }^{\circ} \mathrm{C}$ (room temperature). Exact mass was calculated on $\mathrm{M}+\mathrm{Na}$ for electrospray ionization, or on the parent for electron impact ionization as indicated.

(1) Minguez, J. M.; Kim, S.-Y.; Giuliano, K. A.; Balachandran, R.; Madiraju, C.; Day, B. W.; Curran, D. P. Bioorg. Med. Chem. 2003, 11, 3335.

(2) Still, W. C.; Kahn, M.; Mitra, A. J. Org. Chem. 1978, 43, 2923. 
Aldehyde 3 was synthesized from known compound $\mathbf{S 1}^{3}$ by the sequence shown in Scheme S1 below.
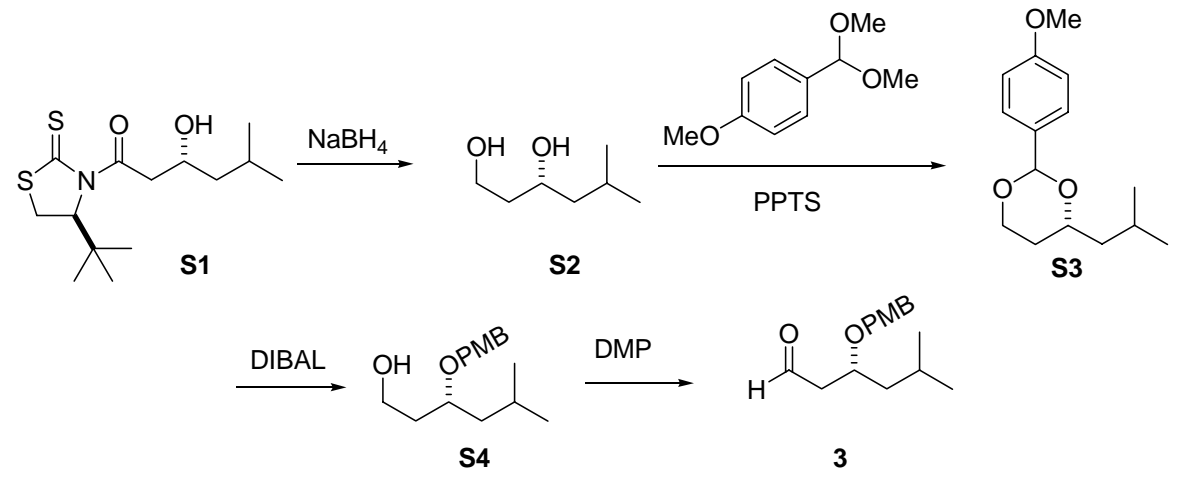

Scheme S1

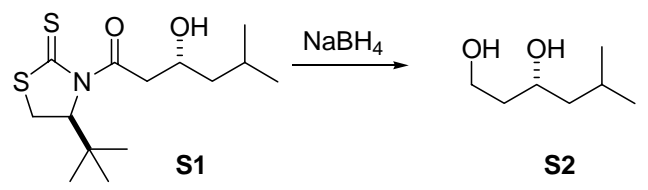

Diol S2. To a cooled $\left(0{ }^{\circ} \mathrm{C}\right)$ yellow solution of compound S1 (1.05g, $3.46 \mathrm{mmol}, 1.00$ eq) in ethanol $(10 \mathrm{~mL})$ was added $\mathrm{NaBH}_{4}(392 \mathrm{mg}, 10.38 \mathrm{mmol}, 3.00 \mathrm{eq})$ in three portions over two minutes. The reaction was warmed to room temperature and stirred until the yellow solution became colorless. The reaction was then quenched by the addition of saturated $\mathrm{NH}_{4} \mathrm{Cl}(10 \mathrm{~mL})$ and stirred for $5 \mathrm{~min}$. The mixture was diluted with $\mathrm{CH}_{2} \mathrm{Cl}_{2}(10 \mathrm{~mL})$, and the phases were separated. The aqueous phase was extracted with $\mathrm{CH}_{2} \mathrm{Cl}_{2}(20 \mathrm{~mL}$ x2), and the combined organic phases were dried over $\mathrm{MgSO}_{4}$ and concentrated at reduced pressure using a rotary evaporator. The residue was dissolved in methanol $(5 \mathrm{~mL})$ to convert any borate esters to trimethylborate and concentrated at reduced pressure. This procedure was repeated two more times to ensure distillation of all the trimethyl borate, and the product was then purified by flash chromatography (1:1 hexanes:ethyl acetate) to provide diol S2 (420 mg, $3.177 \mathrm{mmol}, 92 \%$ ) as a colorless oil.

${ }^{1} \mathrm{H}$ NMR $\left(400 \mathrm{MHz}, \mathrm{CDCl}_{3}\right): \delta 3.95-3.76(\mathrm{~m}, 3 \mathrm{H}), 2.81(\mathrm{br}, \mathrm{s}, \mathrm{OH}), 2.66(\mathrm{br}, \mathrm{s}, \mathrm{OH})$, $1.76-1.58(\mathrm{~m}, 3 \mathrm{H}), 1.44(\mathrm{~m}, 1 \mathrm{H}), 1.23(\mathrm{~m}, 1 \mathrm{H}), 0.89(\mathrm{~d}, 6 \mathrm{H}, \mathrm{J}=6.60 \mathrm{~Hz}) .{ }^{13} \mathrm{C} \mathrm{NMR}(400 \mathrm{MHz}$, $\left.\mathrm{CDCl}_{3}\right): \delta 70.5,62.0,47.2,38.9,24.6,23.5,22.4$. IR $\left(\mathrm{cm}^{-1}\right): 3375,2955,2924 .[\alpha]_{\mathrm{D}}=10.6(\mathrm{c}$ 0.075, EtOAc). HRMS m/z calc'd for $\mathrm{C}_{7} \mathrm{H}_{16} \mathrm{O}_{2}$ : 132.1150; found:132.1145.

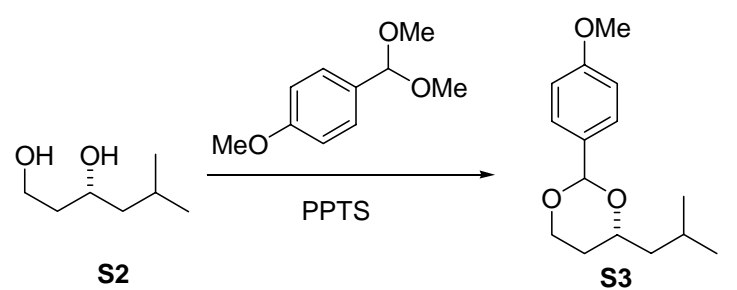

PMB acetal S3. To a cooled $\left(0{ }^{\circ} \mathrm{C}\right)$ solution of diol S2 $(400 \mathrm{mg}, 3.025 \mathrm{mmol}, 1.0 \mathrm{eq})$ in $\mathrm{CH}_{2} \mathrm{Cl}_{2}(5 \mathrm{~mL})$ was added $p$-anisaldehyde dimethyl acetal $(0.773 \mathrm{~mL}, 4.538 \mathrm{mmol}, 1.5 \mathrm{eq})$ by syringe. PPTS (152 mg, $0.605 \mathrm{mmol}, 0.2 \mathrm{eq})$ was then added in one portion and the solution

(3) Zhang, Y; Phillips, A. J.; Sammakia, T. Org Lett. 2004, 6, 23. 
stirred for $1 \mathrm{~h}$ at $0{ }^{\circ} \mathrm{C}$. The reaction was then filtered through a short plug of silica with a layer of celite on top using ether as the eluent, and concentrated at reduced pressure using a rotary evaporator. Flash chromatography (25:1 hexanes:ethyl acetate) provided analytically pure S3 as a colorless oil (704 mg, $2.813 \mathrm{mmol}, 93 \%)$.

${ }^{1} \mathrm{H}$ NMR $\left(400 \mathrm{MHz}, \mathrm{CDCl}_{3}\right): \delta 7.39(\mathrm{~m}, 2 \mathrm{H}), 6.86(\mathrm{~m}, 2 \mathrm{H}), 5.45(\mathrm{~s}, 1 \mathrm{H}), 4.24(\mathrm{~m}, 1 \mathrm{H})$ $3.95(\mathrm{~m}, 1 \mathrm{H}), 3.87(\mathrm{~m}, 1 \mathrm{H}), 3.78(\mathrm{~s}, 3 \mathrm{H}), 1.86(\mathrm{~m}, 1 \mathrm{H}), 1.77(\mathrm{~m}, 1 \mathrm{H}), 1.63(\mathrm{~m}, 1 \mathrm{H}), 1.46(\mathrm{~m}, 1 \mathrm{H})$, $1.30(\mathrm{~m}, 1 \mathrm{H}), 0.93(\mathrm{~d}, 3 \mathrm{H}, \mathrm{J}=6.60 \mathrm{~Hz}), 0.91(\mathrm{~d}, 3 \mathrm{H}, \mathrm{J}=6.60 \mathrm{~Hz}) .{ }^{13} \mathrm{C}$ NMR $\left(400 \mathrm{MHz}, \mathrm{CDCl}_{3}\right)$ : $159.9,131.7,127.7,101.1,75.6,67.3,55.5,45.3,31.9,24.1,23.3,22.6$. IR $\left(\mathrm{cm}^{-1}\right): 2951,2917$, 1612, 1518. $[\alpha]_{\mathrm{D}}=56.7$ (c 0.250 , EtOAc). HRMS m/z calc'd for $\mathrm{C}_{15} \mathrm{H}_{22} \mathrm{O}_{3} \mathrm{Na}^{+}: 273.1461$; found: 273.1463 .

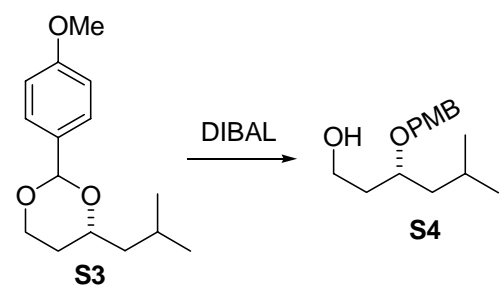

Alcohol S4. To a cooled $\left(0{ }^{\circ} \mathrm{C}\right)$ solution of S3 $(650 \mathrm{mg}, 2.596 \mathrm{mmol}, 1.0$ equiv) in $\mathrm{CH}_{2} \mathrm{Cl}_{2}(8 \mathrm{~mL})$ was added DIBAL-H $(3.89 \mathrm{~mL}, 1.00 \mathrm{M}$ in hexanes, $3.894 \mathrm{mmol}$, 1.5 equiv) dropwise. The resulting solution was stirred for $10 \mathrm{~min}$ at $0{ }^{\circ} \mathrm{C}$ then allowed to warm to room temperature and stirred for $4 \mathrm{~h}$. The reaction was then quenched by careful addition of saturated potassium sodium tartrate $(8 \mathrm{~mL})$ and stirred vigorously for $2 \mathrm{~h}$. The aqueous phase was saturated with $\mathrm{NaCl}$, separated, then extracted with 1:1 $\mathrm{CH}_{2} \mathrm{Cl}_{2}: \mathrm{Et}_{2} \mathrm{O}(10 \mathrm{~mL}, 3 \mathrm{x})$. The combined organic phases were dried over $\mathrm{MgSO}_{4}$ and concentrated at reduced pressure using a rotary evaporator. Flash chromatography (4:1 hexanes:ethyl acetate) provided alcohol S4 (563 $\mathrm{mg}, 2.23 \mathrm{mmol}, 86 \%$ ) as a colorless oil.

${ }^{1} \mathrm{H}$ NMR (400 MHz, $\left.\mathrm{CDCl}_{3}\right): \delta 7.25(\mathrm{~m}, 2 \mathrm{H}), 6.88(\mathrm{~m}, 2 \mathrm{H}), 4.49$ (A of $\mathrm{AB}, \mathrm{J}=11.00 \mathrm{~Hz}$ ), $4.42(\mathrm{~B}$ of $\mathrm{AB}, \mathrm{J}=11.00 \mathrm{~Hz}), 3.78(\mathrm{~m}, 1 \mathrm{H}), 3.78(\mathrm{~s}, 3 \mathrm{H}), 3.67(\mathrm{~m}, 2 \mathrm{H}), 2.49(\mathrm{~d}, \mathrm{OH}, \mathrm{J}=5.22 \mathrm{~Hz})$, $1.85(\mathrm{~m}, 1 \mathrm{H}), 1.68(\mathrm{~m}, 2 \mathrm{H}), 1.64(\mathrm{~m}, 1 \mathrm{H}), 1.28(\mathrm{~m}, 1 \mathrm{H}), 0.88(\mathrm{~d}, 3 \mathrm{H}, \mathrm{J}=6.40 \mathrm{~Hz}), 0.86(\mathrm{~d}, 3 \mathrm{H}$, $\mathrm{J}=6.40 \mathrm{~Hz}$ ). ${ }^{13} \mathrm{C} \mathrm{NMR}\left(400 \mathrm{MHz}, \mathrm{CDCl}_{3}\right): 159.4,130.7,129.7,114.1,70.7,60.9,55.5,43.2$, 36.1, 24.9, 23.3, 23.0. IR $\left(\mathrm{cm}^{-1}\right): 3414,2951,2918,1612,1510 . \quad[\alpha]_{\mathrm{D}}=-2.71$ (c 0.025, EtOAc). HRMS m/z calc'd for $\mathrm{C}_{15} \mathrm{H}_{24} \mathrm{O}_{3} \mathrm{Na}^{+}: 275.1617$; found: 275.1605 .

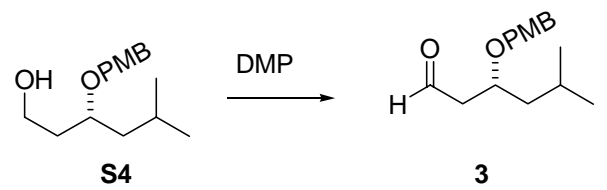

Aldehyde 3. To a cooled $\left(0{ }^{\circ} \mathrm{C}\right)$ solution of alcohol S4 $(500 \mathrm{mg}, 1.98 \mathrm{mmol}, 1.0 \mathrm{eq})$ in $\mathrm{CH}_{2} \mathrm{Cl}_{2}(10 \mathrm{~mL})$ was added Dess-Martin periodinane ${ }^{4}$ (1.008 g, $\left.2.38 \mathrm{mmol}, 1.2 \mathrm{eq}\right)$. The resulting solution was allowed to warm to room temperature and stirred for $2 \mathrm{~h}$. The reaction was then concentrated at reduced pressure to a volume of $3 \mathrm{~mL}$ and directly subjected to purification by flash chromatography (20:1 hexanes : ethylacetate) to provide aldehyde 3 ( 450 mg, $91 \%$ ) as a colorless oil.

(4) Dess, D. B.; Martin, J. C. J. Am. Chem. Soc. 1991, 113, 7277, Ireland, RE; Liu, L. J. Org. Chem. 1993 58, 2899, Boeckman, R. K.; Shao, P.; Mullins, J. J. In Organic Syntheses; Wiley \& Sons: New York, 2004; Collect. Vol. X, p 696. 
${ }^{1} \mathrm{H}$ NMR $\left(400 \mathrm{MHz}, \mathrm{CDCl}_{3}\right): \delta 9.80(\mathrm{t}, 1 \mathrm{H}, \mathrm{J}=2.20 \mathrm{~Hz}), 7.24(\mathrm{~m}, 2 \mathrm{H}), 6.87(\mathrm{~m}, 2 \mathrm{H}), 4.48$ $(\mathrm{d}, \mathrm{A}$ of $\mathrm{AB}, \mathrm{J}=11.2 \mathrm{~Hz}), 4.46(\mathrm{~d}, \mathrm{~A}$ of $\mathrm{AB}, \mathrm{J}=11.2 \mathrm{~Hz}), 4.00(\mathrm{~m}, 1 \mathrm{H}), 3.80(\mathrm{~s}, 3 \mathrm{H}), 2.61(\mathrm{~m}, 2 \mathrm{H})$, $\mathrm{I} .73(\mathrm{~m}, 1 \mathrm{H}), 1.63(\mathrm{~m}, 1 \mathrm{H}), 1.30(\mathrm{~m}, 1 \mathrm{H}), 0.89(\mathrm{~d}, 3 \mathrm{H}, \mathrm{J}=3.95 \mathrm{~Hz}) .0 .88(\mathrm{~d}, 3 \mathrm{H}, \mathrm{J}=3.95 \mathrm{~Hz}) .{ }^{13} \mathrm{C}$ NMR (400 MHz, $\left.\mathrm{CDCl}_{3}\right): \delta 202.1,159.5,130.5,129.7,114.0,72.6,71.1,55.5,48.8,44.2,24.8$, 23.2, 22.7, 22.6, 14.3. IR $\left(\mathrm{cm}^{-1}\right): 2959,2919,1724,1612,1511 .[\alpha]_{\mathrm{D}}=26.9$ (c 0.150, EtOAc). HRMS m/z calc'd for $\mathrm{C}_{15} \mathrm{H}_{22} \mathrm{O}_{3} \mathrm{Na}^{+}$: 273.1461; found: 273.1459 .

Aldehyde 5 was synthesized from known compound $\mathbf{S 5 ^ { 5 , 6 }}$ by the sequence shown in Scheme S2 below.

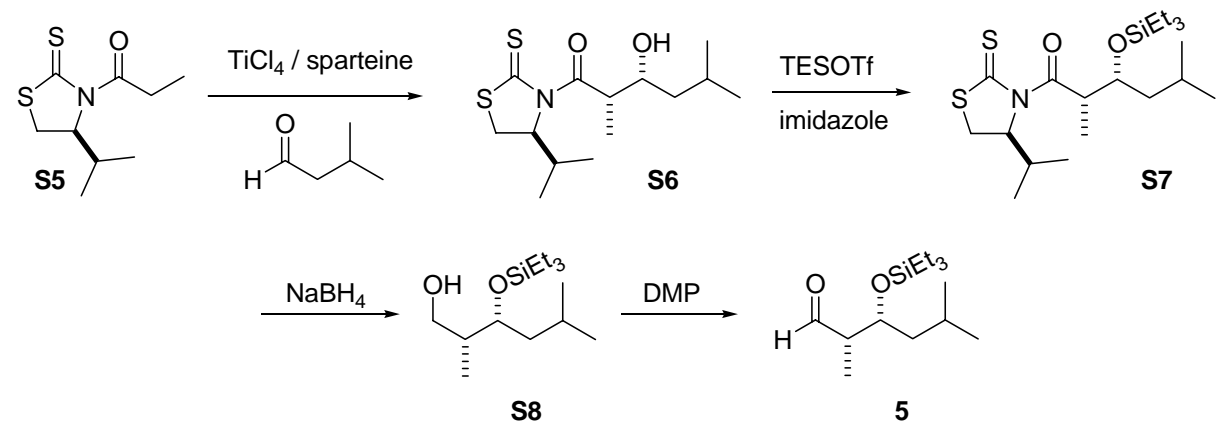

Scheme S2

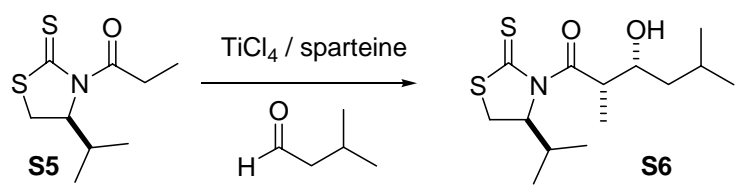

Aldol adduct S6. To a cooled $\left(0{ }^{\circ} \mathrm{C}\right)$ solution of thiazolidinethione S5 (652 $\mathrm{mg}, 3.00$ mmol, 1.0 eq) in $\mathrm{CH}_{2} \mathrm{Cl}_{2}(8 \mathrm{~mL})$ was added $\mathrm{TiCl}_{4}\left(1.0 \mathrm{M}\right.$ solution in $\mathrm{CH}_{2} \mathrm{Cl}_{2}, 3.15 \mathrm{~mL}, 3.15$ mmol, $1.05 \mathrm{eq})$ dropwise. The resulting bronze colored solution was stirred for $5 \mathrm{~min}$, then (-)sparteine (1.28 mL, $6.00 \mathrm{mmol}, 2.0 \mathrm{eq})$ was added dropwise. Upon addition of the sparteine, the reaction immediately turned a deep red color. The reaction was stirred at $0{ }^{\circ} \mathrm{C}$ for $20 \mathrm{~min}$ and then cooled to $-78{ }^{\circ} \mathrm{C}$, at which point 3 -methyl-butyraldehyde $(0.487 \mathrm{~mL}, 4.50 \mathrm{mmol}, 1.5 \mathrm{eq})$ was added dropwise. The reaction was stirred for $1 \mathrm{~h}$ at $-78{ }^{\circ} \mathrm{C}$, then warmed to $0{ }^{\circ} \mathrm{C}$ over a period of about 20 minutes. The reaction was then quenched with a half-saturated $\mathrm{NH}_{4} \mathrm{Cl}$ solution $(10 \mathrm{~mL})$ and warmed to room temperature. The $\mathrm{CH}_{2} \mathrm{Cl}_{2}$ layer was separated, and the aqueous phase was further extracted with $\mathrm{CH}_{2} \mathrm{Cl}_{2}$. The combined organic extracts were dried over $\mathrm{MgSO}_{4}$, filtered, and concentrated at reduced pressure by rotary evaporation to yield a pale orange oil. Analysis of this material by ${ }^{1} \mathrm{H}$ NMR indicated a 30:1 diastereomeric ratio. The product was purified by flash chromatography on neutral silica gel (15:1 hexanes:ethyl acetate, see general information for details regarding the use of neutral silica gel) to yield the alcohol S6 (850 mg, $2.80 \mathrm{mmol}, 93 \%$ ) as a yellow oil.

${ }^{1} \mathrm{H}$ NMR $\left(400 \mathrm{MHz}, \mathrm{CDCl}_{3}\right): \delta 5.17(\mathrm{ddd}, 1 \mathrm{H}, \mathrm{J}=1.20,6.40,7.80 \mathrm{~Hz}), 4.38(\mathrm{dq}, 1 \mathrm{H}$, $\mathrm{J}=2.56,6.95 \mathrm{~Hz}), 3.97(\mathrm{~m}, 1 \mathrm{H}), 3.50$ (A of ABX, 1H, J=7.80, 11.50 Hz), 3.01 (B of ABX, 1H,

(5) Nagao, Y.; Kumagai, T.; Nagase, Y.; Tamai, S.; Inoue, Y.; Shiro, M. J. Org. Chem. 1992, 57, 4232.

(6) Crimmins, M. T.; Chaudhary, K. Org. Lett. 2000, 2, 775. 
$\mathrm{J}=1.20,11.50 \mathrm{~Hz}), 2.88(\mathrm{~d}, \mathrm{OH}, \mathrm{J}=3.00 \mathrm{~Hz}), 2.30(\mathrm{~m}, 1 \mathrm{H}), 1.75(\mathrm{~m}, 1 \mathrm{H}), 1.48(\mathrm{~m}, 1 \mathrm{H}), 1.24(\mathrm{~d}$, $3 \mathrm{H}, \mathrm{J}=6.80 \mathrm{~Hz}), 1.08(\mathrm{~m}, 1 \mathrm{H}), 1.04(\mathrm{~d}, 3 \mathrm{H}, \mathrm{J}=6.80 \mathrm{~Hz}), 0.94(\mathrm{~d}, 3 \mathrm{H}, \mathrm{J}=7.80 \mathrm{~Hz}), 0.89$ (d, 3H, $\mathrm{J}=6.70 \mathrm{~Hz}), 0.88(\mathrm{~d}, 3 \mathrm{H}, \mathrm{J}=6.70 \mathrm{~Hz}) .{ }^{13} \mathrm{C} \mathrm{NMR}\left(400 \mathrm{MHz}, \mathrm{CDCl}_{3}\right): \delta 202.9,179.0,71.7,69.9$, 43.3, 43.2, 31.0, 30.7, 24.7, 23.7, 22.2, 19.2, 18.1, 11.3. IR $\left(\mathrm{cm}^{-1}\right): 3437,2959,1685 . \quad[\alpha]_{\mathrm{D}}=$ 395 (c 1.65, EtOAc). HRMS m/z calc'd for $\mathrm{C}_{14} \mathrm{H}_{25} \mathrm{NO}_{2} \mathrm{~S}_{2} \mathrm{Na}^{+}: 326.1219$; found: 326.1224 .

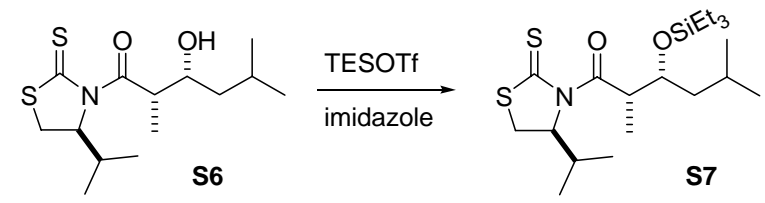

TES ether S7. To a solution of alcohol $\mathbf{S 6}(800 \mathrm{mg}, 2.64 \mathrm{mmol}, 1.0 \mathrm{eq})$ and imidazole (269 $\mathrm{mg}, 3.95 \mathrm{mmol}, 1.5 \mathrm{eq})$ in dichloromethane $(3 \mathrm{~mL})$ was added triethylsilyl triflate $(0.775$ $\mathrm{mL}, 3.43 \mathrm{mmol}, 1.3 \mathrm{eq})$ at $0{ }^{\circ} \mathrm{C}$. The resulting solution was warmed to room temperature and stirred for $1 \mathrm{~h}$, then quenched with a saturated solution of $\mathrm{NaHCO}_{3}$. The organic layer was separated and the aqueous layer was extracted with dichloromethane. The combined organic extracts were dried over $\mathrm{MgSO}_{4}$, filtered, then concentrated at reduced pressure. Flash chromatography on neutral silica gel (30:1 hexanes:ethyl acetate, see general information for details regarding the use of neutral silica gel) provided S7 (973 $\mathrm{mg}, 2.345 \mathrm{mmol}, 89 \%$ ) as a yellow oil.

${ }^{1} \mathrm{H}$ NMR $\left(400 \mathrm{MHz}, \mathrm{CDCl}_{3}\right): \delta 4.99(\mathrm{ddd}, 1 \mathrm{H}, \mathrm{J}=0.90,6.13,8.00 \mathrm{~Hz}), 4.55(\mathrm{~m}, 1 \mathrm{H}), 4.00$ (m, 1H), 3.43 (A of ABX, 1H, J=7.78, 11.50 Hz), 3.00 (B of ABX, 1H, J=0.90, 11.50 Hz), 2.38 $(\mathrm{m}, 1 \mathrm{H}), 1.60(\mathrm{~m}, 1 \mathrm{H}), 1.40(\mathrm{~m}, 1 \mathrm{H}), 1.25(\mathrm{~m}, 1 \mathrm{H}), 1.17(\mathrm{~d}, 3 \mathrm{H}, \mathrm{J}=6.80 \mathrm{~Hz}), 1.04(\mathrm{~d}, 3 \mathrm{H}, \mathrm{J}=6.80$ $\mathrm{Hz}), 0.94(\mathrm{t}, 9 \mathrm{H}, \mathrm{J}=8.00 \mathrm{~Hz}), 0.92(\mathrm{~d}, 3 \mathrm{H}, \mathrm{J}=6.80 \mathrm{~Hz}), 0.88(\mathrm{~d}, 3 \mathrm{H}, \mathrm{J}=6.70 \mathrm{~Hz}), 0.86(\mathrm{~d}, 3 \mathrm{H}$, $\mathrm{J}=6.70 \mathrm{~Hz}), 0.58(\mathrm{q}, 6 \mathrm{H}, \mathrm{J}=8.20 \mathrm{~Hz}) .{ }^{13} \mathrm{C}$ NMR $\left(400 \mathrm{MHz}, \mathrm{CDCl}_{3}\right): \delta 202.9,176.6,72.8,72.5$, 45.2, 42.8, 31.2, 30.9, 24.6, 24.1, 22.7, 19.3, 18.1, 13.2, 7.3, 5.5. IR ( $\left.\mathrm{cm}^{-1}\right): 2955,2873,1689$. $[\alpha]_{\mathrm{D}}=362$ (c 0.65 , EtOAc). HRMS m/z calc'd for $\mathrm{C}_{20} \mathrm{H}_{39} \mathrm{NO}_{2} \mathrm{~S}_{2} \mathrm{SiNa}^{+}: 440.2084$; found: 440.2084 .

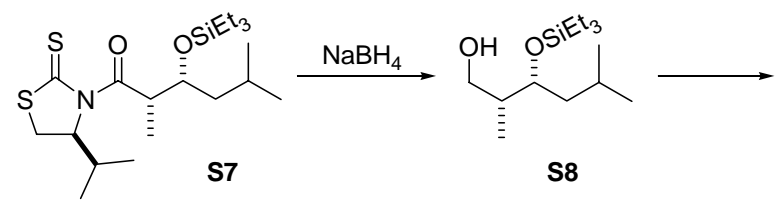

Alcohol S8. To a cooled $\left(0{ }^{\circ} \mathrm{C}\right)$ yellow solution of compound S7 $(900 \mathrm{mg}, 2.17 \mathrm{mmol}$, $1.00 \mathrm{eq})$ in ethanol $(8 \mathrm{~mL})$ was added $\mathrm{NaBH}_{4}(246 \mathrm{mg}, 6.51 \mathrm{mmol}, 3.00 \mathrm{eq})$ in three portions over 2 minutes. The reaction was warmed to room temperature and stirred until the yellow solution became colorless (about 30 minutes). The reaction was then quenched by the addition of saturated $\mathrm{NH}_{4} \mathrm{Cl}(10 \mathrm{~mL})$ and stirred for $5 \mathrm{~min}$. $\mathrm{CH}_{2} \mathrm{Cl}_{2}(10 \mathrm{~mL})$ was then added, and phases were separated. The aqueous phase was extracted with $\mathrm{CH}_{2} \mathrm{Cl}_{2}(20 \mathrm{~mL} \mathrm{x2})$, and the combined organic phases were dried over $\mathrm{MgSO}_{4}$ and concentrated at reduced pressure using a rotary evaporator. The residue was dissolved in methanol $(5 \mathrm{~mL})$ to convert any borate esters to trimethylborate and concentrated at reduced pressure. This procedure was repeated two more times to ensure distillation of all the trimethyl borate, and the product was then purified by flash chromatography (8:1 hexanes:ethyl acetate) to provide alcohol S8 $(537 \mathrm{mg}, 2.062 \mathrm{mmol}, 95 \%)$ as a colorless oil.

${ }^{1} \mathrm{H}$ NMR (400 MHz, $\left.\mathrm{CDCl}_{3}\right): \delta 3.83(\mathrm{~m}, 1 \mathrm{H}), 3.62(\mathrm{~m}, 1 \mathrm{H}), 3.46(\mathrm{~m}, 1 \mathrm{H}), 2.99$ (br, s, $\mathrm{OH}), 1.88(\mathrm{~m}, 1 \mathrm{H}), 1.59(\mathrm{~m}, 1 \mathrm{H}), 1.33(\mathrm{~m}, 1 \mathrm{H}), 1.23(\mathrm{~m}, 1 \mathrm{H}), 0.91(\mathrm{t}, 9 \mathrm{H}, \mathrm{J}=8.10 \mathrm{~Hz}), 0.86(\mathrm{~d}$, 
$3 \mathrm{H}, \mathrm{J}=6.70 \mathrm{~Hz}), 0.82(\mathrm{~d}, 3 \mathrm{H}, \mathrm{J}=6.70 \mathrm{~Hz}), 0.74(\mathrm{~d}, 3 \mathrm{H}, \mathrm{J}=7.00 \mathrm{~Hz}), 0.56(\mathrm{q}, 6 \mathrm{H}, \mathrm{J}=8.10 \mathrm{~Hz}) .{ }^{13} \mathrm{C}$ NMR (400 MHz, $\left.\mathrm{CDCl}_{3}\right): 74.0,66.2,41.9,39.7,24.5,23.4,22.6,11.8,7.0,5.3$. IR $\left(\mathrm{cm}^{-1}\right): 3355$, 2955, 2874, 1456. $[\alpha]_{\mathrm{D}}=-12.5$ (c 0.900, EtOAc). HRMS m/z calc'd for $\mathrm{C}_{14} \mathrm{H}_{32} \mathrm{O}_{2} \mathrm{Si}^{+}$: 260.2166; found:260.2176.

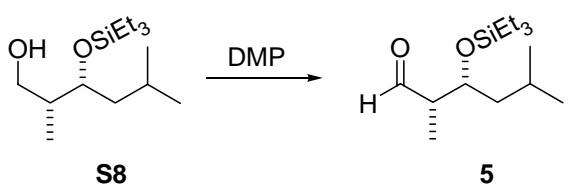

Aldehyde 5. To a cooled $\left(0{ }^{\circ} \mathrm{C}\right)$ solution of alcohol S8 $(400 \mathrm{mg}, 1.54 \mathrm{mmol}, 1.0 \mathrm{eq})$ in $\mathrm{CH}_{2} \mathrm{Cl}_{2}(8 \mathrm{~mL})$ was added Dess-Martin periodinane (782 mg, $\left.1.84 \mathrm{mmol}, 1.2 \mathrm{eq}\right)$. The resulting solution was warmed to room temperature and stirred for $2 \mathrm{~h}$. The reaction was then concentrated at reduced pressure to a volume of about $3 \mathrm{~mL}$ and directly subjected to purification by flash chromatography (25:1 hexanes : ethylacetate) to provide aldehyde 5 (365 $\mathrm{mg}, 1.41 \mathrm{mmol}, 92 \%$ ) as a colorless oil.

${ }^{1} \mathrm{H}$ NMR (400 MHz, $\left.\mathrm{CDCl}_{3}\right): 9.76(\mathrm{~d}, 1 \mathrm{H}, \mathrm{J}=0.92 \mathrm{~Hz}), 4.18(\mathrm{~m}, 1 \mathrm{H}), 2.40(\mathrm{~m}, 1 \mathrm{H}), 1.60$ $(\mathrm{m}, 1 \mathrm{H}), 1.31(\mathrm{~m}, 2 \mathrm{H}), 1.02(\mathrm{~d}, 3 \mathrm{H}, \mathrm{J}=6.96 \mathrm{~Hz}), 0.90(\mathrm{~d}, 3 \mathrm{H}, \mathrm{J}=6.50 \mathrm{~Hz}), 0.89$ (t, 9H, J=7.80 Hz), $0.88(\mathrm{~d}, 3 \mathrm{H}, \mathrm{J}=6.50 \mathrm{~Hz}), 0.56(\mathrm{q}, 6 \mathrm{H}, \mathrm{J}=7.80 \mathrm{~Hz}) .{ }^{13} \mathrm{C} \mathrm{NMR}\left(400 \mathrm{MHz}, \mathrm{CDCl}_{3}\right): \delta 205.8,70.5$, 51.6, 43.9, 24.8, 23.0, 22.9, 7.7, 7.1, 5.3. IR $\left(\mathrm{cm}^{-1}\right): 2959,2877,1728,1460 .[\alpha]_{\mathrm{D}}=47.3(\mathrm{c}$ 0.550, EtOAc). HRMS m/z calc'd for $\mathrm{C}_{14} \mathrm{H}_{30} \mathrm{O}_{2} \mathrm{SiNa}^{+}: 281.1907$; found: 281.1900 .

Aldehyde 6 was synthesized from known compound S9 by the sequence shown in Scheme S3 below.

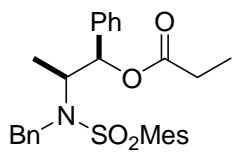

S9

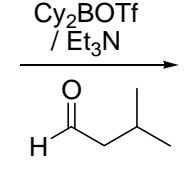

$\mathrm{Bn}^{-\mathrm{N}} \mathrm{SO}_{2} \mathrm{SP}_{\mathrm{S} 10}$
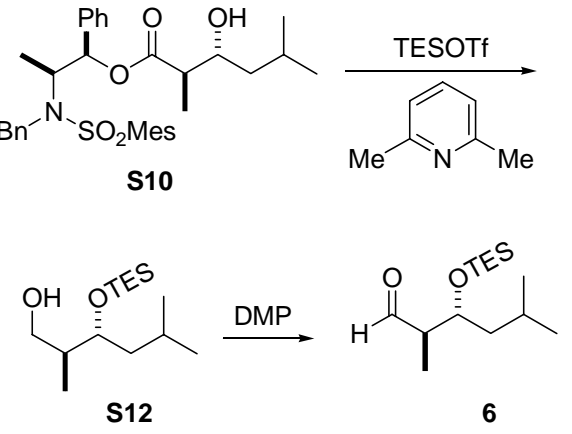

Scheme S3
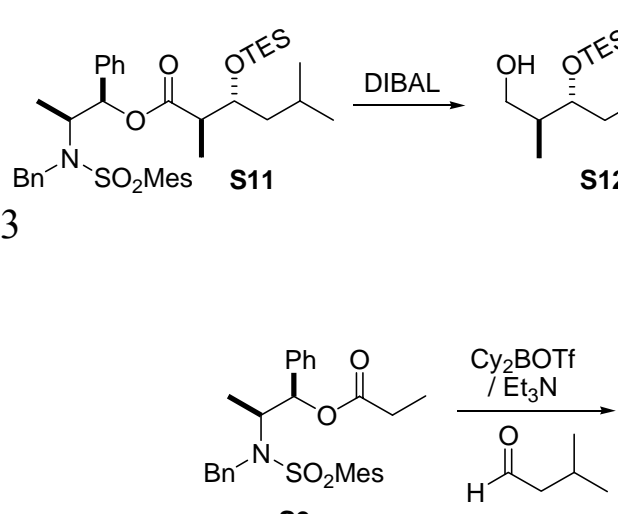

s9

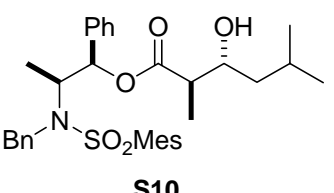

Dicyclohexylborontriflate $\left(6.600 \mathrm{mmol}\right.$ in $\left.5 \mathrm{~mL} \mathrm{CH}_{2} \mathrm{Cl}_{2}, 2.2 \mathrm{eq}\right)$ was added dropwise to a $-78{ }^{\circ} \mathrm{C}$ solution of S9 ${ }^{7}(1.440 \mathrm{~g}, 3.000 \mathrm{mmol}, 1.0 \mathrm{eq})$ and $\mathrm{Et}_{3} \mathrm{~N}$ (1.004 mL, $\left.7.200 \mathrm{mmol}, 2.4 \mathrm{eq}\right)$ in $\mathrm{CH}_{2} \mathrm{Cl}_{2}(15 \mathrm{~mL})$. After 2 hours, 3-methyl-butyraldehyde $(0.487 \mathrm{~mL}, 4.500 \mathrm{mmol}, 1.5 \mathrm{eq})$ was added dropwise, and the reaction was stirred for an additional hour at $-78{ }^{\circ} \mathrm{C}$, then warmed to room temperature, and stirred for 1 hour. The reaction was quenched by the addition of $\mathrm{pH} 7$ buffer $(5 \mathrm{~mL}), \mathrm{MeOH}(10 \mathrm{~mL})$, and hydrogen peroxide (5 $\mathrm{ml}$ of a $30 \%$ solution). The resulting

(7) Abiko, A. Organic Syntheses 2002, 79, 109-115. 
mixture was vigorously stirred overnight then diluted with water $(20 \mathrm{~mL})$, and $\mathrm{CH}_{2} \mathrm{Cl}_{2}(40 \mathrm{~mL})$. The layers were separated, and the aqueous layer was extracted with $\mathrm{CH}_{2} \mathrm{Cl}_{2}(40 \mathrm{~mL} \times 3)$. The combined organic extracts were washed with brine $(50 \mathrm{~mL})$, dried over $\mathrm{MgSO}_{4}$, filtered and concentrated at reduced pressure. The product was determined to be a 30:1 mixture of diastereomers by ${ }^{1} \mathrm{H}$ NMR analysis of the crude reaction mixture. Flash chromatography (6:1 hexanes:ethyl acetate) provided alcohol S10 (1.562 g, $2.76 \mathrm{mmol}, 92 \%)$ as a white foam.

${ }^{1} \mathrm{H}$ NMR $\left(400 \mathrm{MHz}, \mathrm{CDCl}_{3}\right): \delta$ 7.30-7.16 (m, 8H), $6.87(\mathrm{~m}, 4 \mathrm{H}), 5.83(\mathrm{~d}, 1 \mathrm{H}, \mathrm{J}=4.40 \mathrm{~Hz})$, 4.76 (A of AB, J=16.50 Hz), 4.54 (B of AB, J=16.50 Hz), $4.13(\mathrm{~m}, 1 \mathrm{H}), 3.68(\mathrm{~m}, 1 \mathrm{H}), 2.49$ (s, 6H), 2.47 (br, s, OH ), $2.45(\mathrm{~m}, 1 \mathrm{H}), 2.28(\mathrm{~s}, 3 \mathrm{H}), 1.83(\mathrm{~m}, 1 \mathrm{H}), 1.37(\mathrm{~m}, 1 \mathrm{H}), 1.18(\mathrm{~m}, 1 \mathrm{H}), 1.18$ (d, 3H, J=7.05 Hz), 1.16 (d, 3H, J=7.23 Hz), 0.89 (d, 3H, J=6.70 Hz), 0.88 (d, 3H, J=6.70 Hz). ${ }^{13} \mathrm{C}$ NMR $\left(400 \mathrm{MHz}, \mathrm{CDCl}_{3}\right): \delta 174.9,142.8,140.5,138.6,138.3,133.5,132.3,128.6,128.5$, $128.2,127.9,127.4,126.2,91.0,78.4,71.5,56.9,48.5,46.2,43.9,24.6,24.0,23.1,21.7,21.1$, 14.4, 13.8. IR $\left(\mathrm{cm}^{-1}\right): 3402,1632$, 1491. $[\alpha]_{\mathrm{D}}=63.7$ (c 0.500 , EtOAc). HRMS m/z calc'd for $\mathrm{C}_{33} \mathrm{H}_{43} \mathrm{O}_{5} \mathrm{SNa}^{+}$: 588.2754; found: 588.2756.
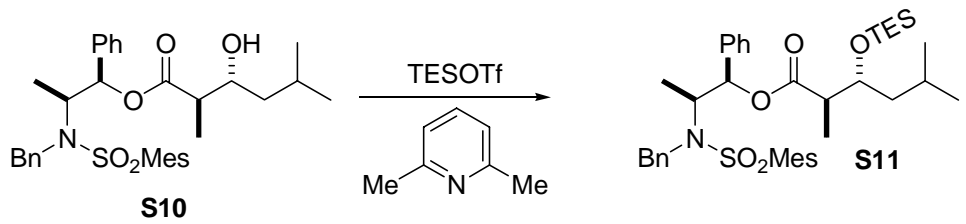

To a solution of alcohol S10 (1.400 g, $2.47 \mathrm{mmol}, 1.0 \mathrm{eq})$ and 2,6-lutidine $(0.858 \mathrm{~mL}$, $7.42 \mathrm{mmol}, 3.0 \mathrm{eq})$ in dichloromethane $(2 \mathrm{~mL})$ was added TESOTf $(1.120 \mathrm{~mL}, 4.948 \mathrm{mmol}, 2.0$ eq) at $0{ }^{\circ} \mathrm{C}$. The reaction was warmed to room temperature and stirred for $20 \mathrm{~h}$, then quenched with saturated $\mathrm{NaHCO}_{3}$. The layers were separated, and the aqueous layer was extracted with dichloromethane. The combined organic extracts were washed with $1 \mathrm{M} \mathrm{HCl}$, saturated $\mathrm{NaHCO}_{3}$ and brine, dried over $\mathrm{MgSO}_{4}$, filtered and concentrated at reduced pressure. Flash chromatography (8:1 hexanes:ethyl acetate) provided ester S11 (1.480 g, $2.177 \mathrm{mmol}, 88 \%$ ) as a white foam.

${ }^{1} \mathrm{H}$ NMR $\left(400 \mathrm{MHz}, \mathrm{CDCl}_{3}\right): \delta 7.38(\mathrm{~m}, 2 \mathrm{H}), 7.31(\mathrm{~m}, 2 \mathrm{H}), 7.28(\mathrm{~m}, 2 \mathrm{H}), 7.16(\mathrm{~m}, 2 \mathrm{H})$, $6.88(\mathrm{~m}, 4 \mathrm{H}), 5.79(\mathrm{~d}, 1 \mathrm{H}, \mathrm{J}=5.20 \mathrm{~Hz}), 4.81$ (A of AB, J=16.30 Hz), 4.56 (B of AB, J=16.30 Hz), $4.13(\mathrm{~m}, 1 \mathrm{H}), 4.06(\mathrm{~m}, 1 \mathrm{H}), 2.55(\mathrm{~m}, 1 \mathrm{H}), 2.47(\mathrm{~s}, 6 \mathrm{H}), 2.32(\mathrm{~s}, 3 \mathrm{H}), 1.62(\mathrm{~m}, 1 \mathrm{H}), 1.34(\mathrm{~m}, 1 \mathrm{H})$, $1.22(\mathrm{~d}, 3 \mathrm{H}, \mathrm{J}=6.92 \mathrm{~Hz}), 1.11(\mathrm{~d}, 3 \mathrm{H}, \mathrm{J}=7.14 \mathrm{~Hz}), 0.98(\mathrm{t}, 9 \mathrm{H}, \mathrm{J}=8.00 \mathrm{~Hz}), 0.93(\mathrm{~m}, 1 \mathrm{H}), 0.82$ (d, $3 \mathrm{H}, \mathrm{J}=6.60 \mathrm{~Hz}), 0.73(\mathrm{~d}, 3 \mathrm{H}, \mathrm{J}=6.60 \mathrm{~Hz}), 0.62(\mathrm{q}, 6 \mathrm{H}, \mathrm{J}=8.00 \mathrm{~Hz}) .{ }^{13} \mathrm{C} \mathrm{NMR}\left(400 \mathrm{MHz}, \mathrm{CDCl}_{3}\right)$ : $172.3,142.7,140.5,138.6,138.4,133.3,132.3,128.6,128.4,128.1,128.0,127.4,126.7,78.1$, $71.5,56.8,48.3,46.3,42.3,24.3,23.8,23.1,22.0,21.1,14.2,10.7,7.1,5.2$. IR $\left(\mathrm{cm}^{-1}\right): 2951$, 2874, 1732, 1448. $[\alpha]_{\mathrm{D}}=28.6$ (c 0.700, EtOAc). HRMS m/z calc'd for $\mathrm{C}_{39} \mathrm{H}_{57} \mathrm{NO}_{5} \mathrm{SSiNa}^{+}$: 702.3619; found: 702.3633 .

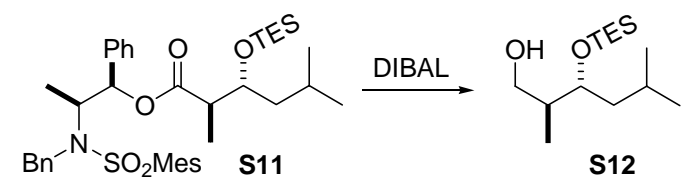

To a cooled $\left(-78{ }^{\circ} \mathrm{C}\right)$ solution of ester S11 (1.400 g, $2.058 \mathrm{mmol}, 1.0$ equiv) in $\mathrm{Et}_{2} \mathrm{O}$ (20 $\mathrm{mL})$ was added DIBAL-H $(5.15 \mathrm{~mL}, 1.00 \mathrm{M}$ in hexanes, $5.15 \mathrm{mmol}, 2.5$ equiv) dropwise. The resulting solution was allowed to warm to room temperature and stirred for $20 \mathrm{~min}$. The reaction was then quenched by careful addition of saturated potassium sodium tartrate $(15 \mathrm{~mL})$ and 
stirred vigorously for $1 \mathrm{~h}$. The aqueous phase was saturated with $\mathrm{NaCl}$ and the phases separated. The aqueous phase was extracted with 1:1 $\mathrm{CH}_{2} \mathrm{Cl}_{2}: \mathrm{Et}_{2} \mathrm{O}(20 \mathrm{~mL} \times 3)$, and the combined organic phases were dried over $\mathrm{MgSO}_{4}$, filtered, and concentrated at reduced pressure using a rotary evaporator. Flash chromatography (10:1 hexanes:ethyl acetate) provided alcohol S12 (466 mg, $1.790 \mathrm{mmol}, 87 \%$ ) as a colorless oil.

${ }^{1} \mathrm{H}$ NMR (400 MHz, $\left.\mathrm{CDCl}_{3}\right): \delta 3.79(\mathrm{~m}, 2 \mathrm{H}), 3.48(\mathrm{~m}, 1 \mathrm{H}), 2.87(\mathrm{br}, \mathrm{OH}), 1.66(\mathrm{~m}, 1 \mathrm{H})$, $1.57(\mathrm{~m}, 1 \mathrm{H}), 1.42(\mathrm{~m}, 2 \mathrm{H}), 1.03(\mathrm{~d}, 3 \mathrm{H}, \mathrm{J}=7.05 \mathrm{~Hz}), 0.93(\mathrm{t}, 9 \mathrm{H}, \mathrm{J}=8.00 \mathrm{~Hz}),, 0.87(\mathrm{~d}, 3 \mathrm{H}$, $\mathrm{J}=6.60 \mathrm{~Hz}), 0.85(\mathrm{~d}, 3 \mathrm{H}, \mathrm{J}=6.60 \mathrm{~Hz}), 0.59$ (q, 6H, J=8.00 Hz). ${ }^{13} \mathrm{C} \mathrm{NMR}\left(400 \mathrm{MHz}, \mathrm{CDCl}_{3}\right)$ : $75.9,65.0,44.5,38.1,24.8,23.5,22.8,15.0,7.1,5.3$. IR $\left(\mathrm{cm}^{-1}\right): 3363,2951,2873,1464 .[\alpha]_{\mathrm{D}}=$ 28.9 (c 0.900, EtOAc). HRMS m/z calc'd for $\mathrm{C}_{14} \mathrm{H}_{32} \mathrm{O}_{2} \mathrm{Si}^{+}: 260.2166$; found:260.2151.

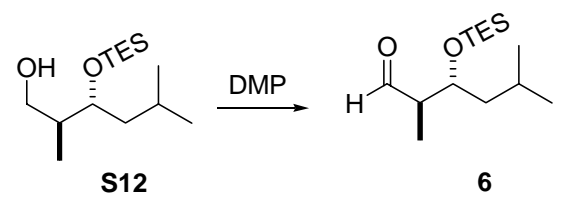

To a $0{ }^{\circ} \mathrm{C}$ solution of alcohol $\mathrm{S12}(400 \mathrm{mg}, 1.54 \mathrm{mmol}, 1.0 \mathrm{eq})$ in $\mathrm{CH}_{2} \mathrm{Cl}_{2}(8 \mathrm{~mL})$ was added Dess-Martin periodinane $(782 \mathrm{mg}, 1.84 \mathrm{mmol}, 1.2 \mathrm{eq})$. The resulting solution was allowed to warm to room temperature and stirred for $2 \mathrm{~h}$. The reaction was then concentrated at reduced pressure to a volume of $3 \mathrm{~mL}$ at reduced pressure, and directly subjected to purification by flash chromatography (25:1 hexanes : ethylacetate) to provide aldehyde 6 (357 $\mathrm{mg}, 1.38$ mmol $90 \%$ ) as a colorless oil.

${ }^{1} \mathrm{H}$ NMR (400 MHz, $\left.\mathrm{CDCl}_{3}\right): 9.76(\mathrm{~d}, 1 \mathrm{H}, \mathrm{J}=2.20 \mathrm{~Hz}), 4.06(\mathrm{~m}, 1 \mathrm{H}), 2.50(\mathrm{~m}, 1 \mathrm{H}), 1.73$ $(\mathrm{m}, 1 \mathrm{H}), 1.50(\mathrm{~m}, 1 \mathrm{H}), 1.29(\mathrm{~m}, 1 \mathrm{H}), 1.15(\mathrm{~d}, 3 \mathrm{H}, \mathrm{J}=7.03 \mathrm{~Hz}), 0.98(\mathrm{t}, 9 \mathrm{H}, \mathrm{J}=7.90 \mathrm{~Hz}), 0.93(\mathrm{~d}$, $3 \mathrm{H}, \mathrm{J}=6.70 \mathrm{~Hz}), 0.92(\mathrm{~d}, 3 \mathrm{H}, \mathrm{J}=6.70 \mathrm{~Hz}), 0.63$ (q, 6H, J=7.90 Hz). ${ }^{13} \mathrm{C} \mathrm{NMR}\left(400 \mathrm{MHz}, \mathrm{CDCl}_{3}\right)$ : 205.1, 71.9, 52.0, 44.5, 24.5, 23.4, 22.7, 10.4, 7.1, 5.3. IR $\left(\mathrm{cm}^{-1}\right): 2959,2877,1724,1464$. [ $\left.\alpha\right]_{\mathrm{D}}$ $=-20.0$ (c 0.700, EtOAc). HRMS m/z calc'd for $\mathrm{C}_{14} \mathrm{H}_{30} \mathrm{O}_{2} \mathrm{SiNa}^{+}:$281.1907; found: 281.1910.

Aldehyde 7 (D-glyceraldehyde acetonide) was purchased and treated with $4 \AA$ molecular sieves in refluxing $\mathrm{CHCl}_{3}$ before use. As received, this material was largely hydrated and not suitable for use in the aldol reaction.

\section{General thiazolidinethione aldol procedure (reproduced from the text of the paper):}
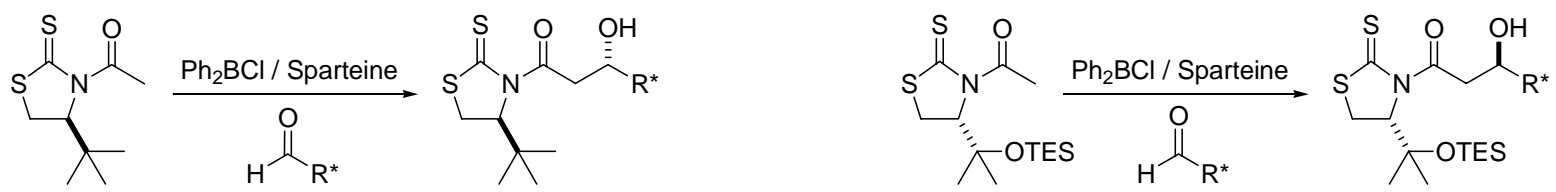

To a $10 \mathrm{~mL}$ round-bottom flask was added the $N$-acetyl thiazolidinethione $(0.250 \mathrm{mmol}$, $1.30 \mathrm{eq})$ and $\mathrm{CH}_{2} \mathrm{Cl}_{2}(1.25 \mathrm{~mL})$. The flask was cooled to $0{ }^{\circ} \mathrm{C}$ and $\mathrm{PhBCl}_{2}(33.3 \mu \mathrm{L}, 0.250$ mmol, $1.30 \mathrm{eq})$ was added dropwise to provide an orange colored solution. After stirring for 5 min, (-)-sparteine $(0.115 \mathrm{~mL}, 0.500 \mathrm{mmol}, 2.6 \mathrm{eq}$.) was added dropwise, at which point the solution turned yellow and cloudy. After stirring for about a minute, the solution became homogenous, but remained yellow. The ice bath was then removed, and the reaction was 
allowed to warm to room temperature and stir for $30 \mathrm{~min}$. The reaction was then cooled to the temperature described in Table 1 , and the aldehyde ( $0.192 \mathrm{mmol}, 1.0$ eq.) in $0.8 \mathrm{~mL} \mathrm{CH}_{2} \mathrm{Cl}_{2}$ was added dropwise via cannula over a period of about $5 \mathrm{~min}$. The flask containing the aldehyde was rinsed with $0.8 \mathrm{~mL} \mathrm{CH}_{2} \mathrm{Cl}_{2}$, which was also added to the reaction via cannula. For entries 1-4 of Table 1 , the reaction was stirred for $6 \mathrm{~h}$ at $-78{ }^{\circ} \mathrm{C}$, and then slowly warmed to $0{ }^{\circ} \mathrm{C}$ over a period of about $3 \mathrm{~h}$ by allowing the dry ice to evaporate. As the temperature approached $0{ }^{\circ} \mathrm{C}$, the reaction was placed in an ice bath and stirred for $30 \mathrm{~min}$. As for entries 5-10 of Table 1, the reaction was stirred for $3 \mathrm{~h}$ at $0{ }^{\circ} \mathrm{C}$. The reaction was then quenched by the addition of hexanes ( $3 \mathrm{~mL})$ and $\mathrm{H}_{2} \mathrm{O}_{2}(30 \%, 1 \mathrm{~mL})$, and stirred rapidly for $10 \mathrm{~min}$ at room temperature. (Note that rapid stirring is required at this step. If the rate of stirring is too slow, incomplete oxidation of the borane occurs, and boron species remain in the product.) The solution was diluted with hexanes and $\mathrm{CH}_{2} \mathrm{Cl}_{2}(4: 1,80 \mathrm{~mL})$, and the layers were separated. The organic layer was further washed with distilled water and brine, dried over anhydrous $\mathrm{MgSO}_{4}$, filtered, and concentrated at reduced pressure to provide an orange oil. Analysis of this material by ${ }^{1} \mathrm{H}$ NMR provided the d.r. values given in Table 1. The products were purified by flash chromatography using neutral silica gel $\left(1: 1\right.$ hexanes $/ \mathrm{CH}_{2} \mathrm{Cl}_{2}$ to $1: 4$ hexanes $/ \mathrm{CH}_{2} \mathrm{Cl}_{2}$ depending on substrate, see general information for details regarding the use of neutral silica gel) to provide the aldol adducts as clear yellow oils. Note that $N$-acyl thiazolidinethiones are sensitive to hydrolysis, and that this work-up has been optimized to minimize hydrolysis, and should be followed carefully in order to obtain high yields and reproducible results.

\section{Compound characterization of the products of Table 1}

Table 1, entry 1:

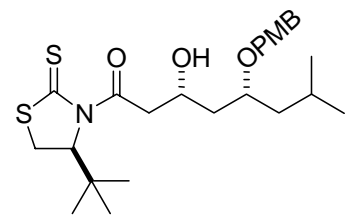

${ }^{1} \mathrm{H}$ NMR (500 MHz, $\left.\mathrm{CDCl}_{3}\right): \delta 7.25(\mathrm{~m}, 2 \mathrm{H}), 6.86(\mathrm{~m}, 2 \mathrm{H}), 5.33(\mathrm{X}$ of ABX, 1H, J=0.73, $8.33 \mathrm{~Hz}), 4.48$ (A of AB, J=11.08 Hz), 4.40 (B of AB, J=11.08 Hz), $4.20(\mathrm{~m}, 1 \mathrm{H}), 3.79$ (s, 3H), $3.66(\mathrm{~m}, 1 \mathrm{H}), 3.61(\mathrm{~d}, \mathrm{OH}, \mathrm{J}=3.02 \mathrm{~Hz}), 3.55(\mathrm{~A}$ of $\mathrm{ABX}, 1 \mathrm{H}, \mathrm{J}=3.33,11.80 \mathrm{~Hz}), 3.48$ (A of ABX, 1H, J=8.33, $17.49 \mathrm{~Hz}), 3.32(\mathrm{~B}$ of $\mathrm{ABX}, 1 \mathrm{H}, \mathrm{J}=3.84,17.49 \mathrm{~Hz}), 3.10(\mathrm{~B}$ of $\mathrm{ABX}, 1 \mathrm{H}$, $\mathrm{J}=0.73,11.80 \mathrm{~Hz}), 1.83(\mathrm{~m}, 1 \mathrm{H}), 1.68(\mathrm{~m}, 2 \mathrm{H}), 1.55(\mathrm{~m}, 1 \mathrm{H}), 1.33(\mathrm{~m}, 1 \mathrm{H}), 1.00(\mathrm{~s}, 9 \mathrm{H}), 0.90(\mathrm{~d}$, $3 \mathrm{H}, \mathrm{J}=3.94 \mathrm{~Hz}), 0.89$ (d, 3H, J=3.94 Hz). ${ }^{13} \mathrm{C} \mathrm{NMR}\left(400 \mathrm{MHz}, \mathrm{CDCl}_{3}\right): \delta 205.2,172.6,159.4$, $130.8,129.8,114.0,75.9,72.3,70.3,66.8,55.5,45.6,43.6,41.0,38.2,30.7,27.1,24.9,23.2$, 23.1. IR $\left(\mathrm{cm}^{-1}\right): 3452,1685,1607,1507,1460 .[\alpha]_{\mathrm{D}}=269$ (c 1.26, EtOH). HRMS m/z calc'd for $\mathrm{C}_{24} \mathrm{H}_{37} \mathrm{NO}_{4} \mathrm{~S}_{2} \mathrm{Na}^{+}$: 490.2056; found: 490.2075 .

\section{Table 1, entry 2:}

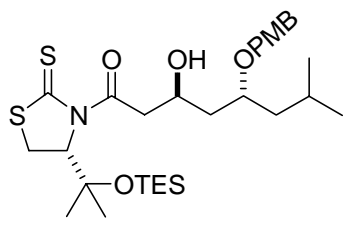


${ }^{1} \mathrm{H}$ NMR (500 MHz, $\left.\mathrm{CDCl}_{3}\right): \delta 7.26(\mathrm{~m}, 2 \mathrm{H}), 6.86(\mathrm{~m}, 2 \mathrm{H}), 5.31$ (X of ABX, 1H, J=1.28, $8.06 \mathrm{~Hz}), 4.51(\mathrm{~A}$ of $\mathrm{AB}, \mathrm{J}=10.90 \mathrm{~Hz}), 4.47(\mathrm{~B}$ of $\mathrm{AB}, \mathrm{J}=10.90 \mathrm{~Hz}), 4.34(\mathrm{~m}, 1 \mathrm{H}), 3.80(\mathrm{~s}, 3 \mathrm{H})$, $3.77(\mathrm{~m}, 1 \mathrm{H}), 3.49(\mathrm{~A}$ of $\mathrm{ABX}, 1 \mathrm{H}, \mathrm{J}=9.17,17.31 \mathrm{~Hz}), 3.48(\mathrm{~d}, \mathrm{OH}, \mathrm{J}=3.10 \mathrm{~Hz}), 3.43$ (A of ABX, $1 \mathrm{H}, \mathrm{J}=8.06,11.53 \mathrm{~Hz}), 3.39(\mathrm{~B}$ of $\mathrm{ABX}, 1 \mathrm{H}, \mathrm{J}=1.28,11.53 \mathrm{~Hz}), 3.30$ (B of ABX, 1H, J=3.39, $17.31 \mathrm{~Hz}), 1.73(\mathrm{~m}, 2 \mathrm{H}), 1.57(\mathrm{~m}, 2 \mathrm{H}), 1.31(\mathrm{~m}, 1 \mathrm{H}), 1.29(\mathrm{~s}, 3 \mathrm{H}), 1.27(\mathrm{~s}, 3 \mathrm{H}), 0.95(\mathrm{t}, 9 \mathrm{H}$, $\mathrm{J}=7.80 \mathrm{~Hz}), 0.91(\mathrm{~d}, 3 \mathrm{H}, \mathrm{J}=6.50 \mathrm{~Hz}), 0.89(\mathrm{~d}, 3 \mathrm{H}, \mathrm{J}=6.50 \mathrm{~Hz}), 0.61(\mathrm{q}, 6 \mathrm{H}, \mathrm{J}=7.80 \mathrm{~Hz}) .{ }^{13} \mathrm{C}$ NMR (400 MHz, $\left.\mathrm{CDCl}_{3}\right): \delta 205.7,172.8,159.3,134.0,129.7,114.0,74.6,72.5,71.3,65.6,55.5$, $45.6,43.8,41.2,30.3,28.3,26.5,24.9,23.2,23.1,7.3,6.8$. IR $\left(\mathrm{cm}^{-1}\right): 3495,1693,1612,1511$, 1460. $[\alpha]_{\mathrm{D}}=-226$ (c 1.27, EtOH). HRMS m/z calc'd for $\mathrm{C}_{29} \mathrm{H}_{49} \mathrm{NO}_{5} \mathrm{~S}_{2} \mathrm{SiNa}^{+}: 606.2713$; found: 606.2707 .

Table 1, entry 3 :

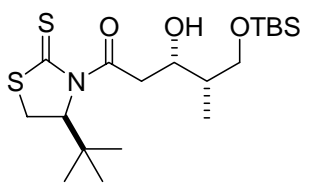

${ }^{1} \mathrm{H}$ NMR $\left(500 \mathrm{MHz}, \mathrm{CDCl}_{3}\right): \delta 5.35(\mathrm{X}$ of $\mathrm{ABX}, 1 \mathrm{H}, \mathrm{J}=0.73,8.33 \mathrm{~Hz}), 4.24(\mathrm{~m}, 1 \mathrm{H})$, $3.64(\mathrm{~d}, 2 \mathrm{H}, \mathrm{J}=5.68 \mathrm{~Hz}), 3.56(\mathrm{~A}$ of $\mathrm{ABX}, 1 \mathrm{H}, \mathrm{J}=7.42,17.13 \mathrm{~Hz}), 3.52$ (A of ABX, 1H, J=8.33, $11.81 \mathrm{~Hz}), 3.35(\mathrm{~d}, \mathrm{OH}, \mathrm{J}=4.31 \mathrm{~Hz}), 3.29(\mathrm{~B}$ of $\mathrm{ABX}, 1 \mathrm{H}, \mathrm{J}=2.84,17.13 \mathrm{~Hz}), 3.10(\mathrm{~B}$ of $\mathrm{ABX}$, $1 \mathrm{H}, \mathrm{J}=0.73,11.81 \mathrm{~Hz}), 1.75(\mathrm{~m}, 1 \mathrm{H}), 1.03(\mathrm{~s}, 9 \mathrm{H}), 0.93(\mathrm{~d}, 3 \mathrm{H}, \mathrm{J}=6.69 \mathrm{~Hz}), 0.88(\mathrm{~s}, 9 \mathrm{H}), 0.05(\mathrm{~s}$, $6 \mathrm{H}) .{ }^{13} \mathrm{C} \mathrm{NMR}\left(400 \mathrm{MHz}, \mathrm{CDCl}_{3}\right): \delta 205.3,173.1,72.5,69.7,66.6,43.0,40.0,38.2,30.7,27.0$, 26.1, 18.5, $11.2-5.2,-5.3$. IR $\left(\mathrm{cm}^{-1}\right): 3503,1689 .[\alpha]_{\mathrm{D}}=309$ (c $\left.0.63, \mathrm{EtOH}\right) . \mathrm{HRMS} \mathrm{m} / \mathrm{z}$ calc'd for $\mathrm{C}_{19} \mathrm{H}_{37} \mathrm{NO}_{3} \mathrm{~S}_{2} \mathrm{SiNa}^{+}$: 442.1876; found: 442.1870 .

Table 1, entry 4:

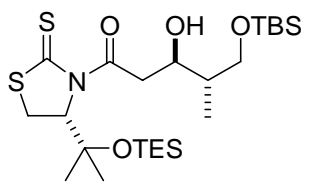

${ }^{1} \mathrm{H}$ NMR $\left(500 \mathrm{MHz}, \mathrm{CDCl}_{3}\right): \delta 5.32(\mathrm{X}$ of ABX, 1H, J=1.28, 8.05 Hz), $4.05(\mathrm{~m}, 1 \mathrm{H})$, $3.72(\mathrm{~d}, 2 \mathrm{H}, \mathrm{J}=4.67 \mathrm{~Hz}), 3.71(\mathrm{~d}, \mathrm{OH}, \mathrm{J}=4.94 \mathrm{~Hz}), 3.64(\mathrm{~A}$ of $\mathrm{ABX}, 1 \mathrm{H}, \mathrm{J}=2.50,16.76 \mathrm{~Hz}), 3.54$ (B of $\mathrm{ABX}, 1 \mathrm{H}, \mathrm{J}=9.33,16.76 \mathrm{~Hz}), 3.46$ (A of ABX, 1H, J=8.05, 11.53 Hz), 3.41 (B of ABX, $1 \mathrm{H}, \mathrm{J}=1.28,11.53 \mathrm{~Hz}), 1.81(\mathrm{~m}, 1 \mathrm{H}), 1.31(\mathrm{~s}, 3 \mathrm{H}), 1.29(\mathrm{~s}, 3 \mathrm{H}), 0.94(\mathrm{t}, 9 \mathrm{H}, \mathrm{J}=8.00 \mathrm{~Hz}), 0.93(\mathrm{~d}$, $3 \mathrm{H}, \mathrm{J}=6.95 \mathrm{~Hz}), 0.89(\mathrm{~s}, 9 \mathrm{H}), 0.61(\mathrm{q}, 6 \mathrm{H}, \mathrm{J}=8.00 \mathrm{~Hz}), 0.06(\mathrm{~s}, 6 \mathrm{H}) .{ }^{13} \mathrm{C} \mathrm{NMR}(400 \mathrm{MHz}$, $\left.\mathrm{CDCl}_{3}\right): \delta 206.0,173.1,76.9,72.7,71.6,66.4,43.0,40.4,30.3,28.4,26.5,26.1,18.5,13.7,7.3$, 6.8, -5.2, -5.3. IR $\left(\mathrm{cm}^{-1}\right): 3472,1685 .[\alpha]_{\mathrm{D}}=-216(\mathrm{c} 0.52, \mathrm{EtOH})$. HRMS m/z calc'd for $\mathrm{C}_{24} \mathrm{H}_{49} \mathrm{NO}_{4} \mathrm{~S}_{2} \mathrm{Si}_{2} \mathrm{Na}^{+}$: 558.2533; found: 558.2514 .

Table 1, entry 5:

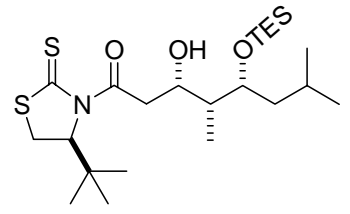

${ }^{1} \mathrm{H}$ NMR $\left(500 \mathrm{MHz}, \mathrm{CDCl}_{3}\right): \delta 5.35(\mathrm{X}$ of $\mathrm{ABX}, 1 \mathrm{H}, \mathrm{J}=0.74,8.43 \mathrm{~Hz}), 4.23(\mathrm{~m}, 1 \mathrm{H})$, $3.93(\mathrm{~m}, 1 \mathrm{H}), 3.57$ (A of ABX, 1H, J=8.52, 17.67 Hz), 3.52 (A of ABX, 1H, J=8.43, 11.72 Hz), 
3.42 (B of ABX, 1H, J=4.03, 17.67 Hz), 3.39 (d, OH, J=3.02 Hz), 3.10 (B of ABX, 1H, J=0.74, $11.72 \mathrm{~Hz}), 1.63(\mathrm{~m}, 1 \mathrm{H}), 1.52(\mathrm{~m}, 2 \mathrm{H}), 1.27(\mathrm{~m}, 1 \mathrm{H}), 1.04(\mathrm{~s}, 9 \mathrm{H}), 0.95(\mathrm{t}, 9 \mathrm{H}, \mathrm{J}=8.05 \mathrm{~Hz}), 0.94$ $(\mathrm{d}, 3 \mathrm{H}, \mathrm{J}=6.96 \mathrm{~Hz}), 0.88(\mathrm{~d}, 3 \mathrm{H}, \mathrm{J}=3.11 \mathrm{~Hz}), 0.86(\mathrm{~d}, 3 \mathrm{H}, \mathrm{J}=3.11 \mathrm{~Hz}), 0.60$ (q, 6H, J=8.05 Hz). ${ }^{13} \mathrm{C}$ NMR (400 MHz, $\left.\mathrm{CDCl}_{3}\right): 205.1,172.6,74.6,72.5,71.1,43.8,43.7,41.1,38.2,30.7,27.1$, 25.0, 23.8, 22.6, 7.8, 7.3, 5.7. IR $\left(\mathrm{cm}^{-1}\right): 3440,1697 .[\alpha]_{\mathrm{D}}=235$ (c 0.60, EtOH). HRMS m/z calc'd for $\mathrm{C}_{23} \mathrm{H}_{45} \mathrm{NO}_{3} \mathrm{~S}_{2} \mathrm{SiNa}^{+}$: 498.2502 ; found: 498.2488 .

Table 1, entry 6:

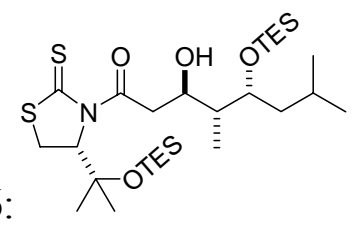

${ }^{1} \mathrm{H}$ NMR $\left(500 \mathrm{MHz}, \mathrm{CDCl}_{3}\right): \delta 5.35(\mathrm{X}$ of ABX, 1H, J=1.28, 8.05 Hz), $4.06(\mathrm{~m}, 1 \mathrm{H})$, $4.04(\mathrm{~m}, 1 \mathrm{H}), 3.96(\mathrm{~d}, \mathrm{OH}, \mathrm{J}=3.67 \mathrm{~Hz}), 3.51(\mathrm{~A}$ of $\mathrm{ABX}, 1 \mathrm{H}, \mathrm{J}=3.02,16.94 \mathrm{~Hz}), 3.47$ (A of ABX, 1H, J=7.96, 11.35 Hz), 3.43 (B of ABX, 1H, J=8.97, $16.94 \mathrm{~Hz}$ ), 3.41 (B of ABX, 1H, $\mathrm{J}=1.28,11.35 \mathrm{~Hz}), 1.70(\mathrm{~m}, 1 \mathrm{H}), 1.60(\mathrm{~m}, 1 \mathrm{H}), 1.40(\mathrm{~m}, 2 \mathrm{H}), 1.30(\mathrm{~s}, 3 \mathrm{H}), 1.29(\mathrm{~s}, 3 \mathrm{H}), 0.96(\mathrm{t}$, $9 \mathrm{H}, \mathrm{J}=8.05 \mathrm{~Hz}), 0.94(\mathrm{t}, 9 \mathrm{H}, \mathrm{J}=7.78 \mathrm{~Hz}), 0.90(\mathrm{~d}, 3 \mathrm{H}, \mathrm{J}=6.59 \mathrm{~Hz}), 0.88(\mathrm{~d}, 3 \mathrm{H}, \mathrm{J}=6.59 \mathrm{~Hz}), 0.80$ $(\mathrm{d}, 3 \mathrm{H}, \mathrm{J}=7.05 \mathrm{~Hz}), 0.62(\mathrm{q}, 6 \mathrm{H}, \mathrm{J}=7.78 \mathrm{~Hz}), 0.60(\mathrm{q}, 6 \mathrm{H}, \mathrm{J}=8.05 \mathrm{~Hz}) .{ }^{13} \mathrm{C} \mathrm{NMR}(400 \mathrm{MHz}$, $\left.\mathrm{CDCl}_{3}\right): \delta 205.7,173.0,77.0,72.8,72.4,70.6,44.3,43.0,42.4,30.3,28.6,26.6,24.9,23.3,23.2$, 11.5, 7.5, 7.3, 7.0, 5.5. IR $\left(\mathrm{cm}^{-1}\right): 3425,1678 .[\alpha]_{\mathrm{D}}=-216$ (c 0.98, EtOH). HRMS m/z calc'd for $\mathrm{C}_{28} \mathrm{H}_{57} \mathrm{NO}_{4} \mathrm{~S}_{2} \mathrm{Si}_{2} \mathrm{Na}^{+}$: 614.3159; found: 614.3154 .

Table 1, entry 7:

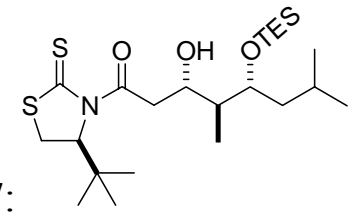

${ }^{1} \mathrm{H}$ NMR $\left(500 \mathrm{MHz}, \mathrm{CDCl}_{3}\right):{ }^{1} \mathrm{H}$ NMR $\left(500 \mathrm{MHz}, \mathrm{CDCl}_{3}\right): \delta 5.34(\mathrm{X}$ of $\mathrm{ABX}, 1 \mathrm{H}$, $\mathrm{J}=0.64,8.34 \mathrm{~Hz}), 4.09(\mathrm{~m}, 1 \mathrm{H}), 3.89(\mathrm{~m}, 1 \mathrm{H}), 3.54(\mathrm{~A}$ of $\mathrm{ABX}, 1 \mathrm{H}, \mathrm{J}=8.34,11.81 \mathrm{~Hz}), 3.46(\mathrm{~m}$, $2 \mathrm{H}), 3.36(\mathrm{~d}, \mathrm{OH}, \mathrm{J}=4.67 \mathrm{~Hz}), 3.12(\mathrm{~B}$ of $\mathrm{ABX}, 1 \mathrm{H}, \mathrm{J}=0.64,11.81 \mathrm{~Hz}), 1.82(\mathrm{~m}, 1 \mathrm{H}), 1.72(\mathrm{~m}$, $1 \mathrm{H}), 1.32(\mathrm{~m}, 1 \mathrm{H}), 1.20(\mathrm{~m}, 1 \mathrm{H}), 1.04(\mathrm{~s}, 9 \mathrm{H}), 0.96(\mathrm{t}, 9 \mathrm{H}, \mathrm{J}=7.80 \mathrm{~Hz}), 0.90(\mathrm{~d}, 3 \mathrm{H}, \mathrm{J}=4.31 \mathrm{~Hz})$, $0.88(\mathrm{~d}, 3 \mathrm{H}, \mathrm{J}=4.31 \mathrm{~Hz}), 0.87(\mathrm{~d}, 3 \mathrm{H}, \mathrm{J}=7.33 \mathrm{~Hz}), 0.61(\mathrm{q}, 6 \mathrm{H}, \mathrm{J}=7.80 \mathrm{~Hz}) .{ }^{13} \mathrm{C} \mathrm{NMR}(400 \mathrm{MHz}$, $\left.\mathrm{CDCl}_{3}\right): \delta 205.3,173.6,72.4,71.3,70.0,44.3,43.4,41.7,38.2,30.8,27.2,24.6,24.1,22.4,11.2$, 7.3, 5.5. IR $\left(\mathrm{cm}^{-1}\right): 3500,1681 .[\alpha]_{\mathrm{D}}=263$ (c 0.63, EtOH). HRMS m/z calc'd for $\mathrm{C}_{23} \mathrm{H}_{45} \mathrm{NO}_{3} \mathrm{~S}_{2} \mathrm{SiNa}^{+}$: 498.2502; found: 498.2519 .

Table 1, entry 8:

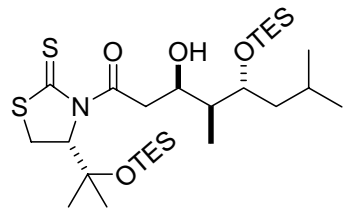

${ }^{1} \mathrm{H}$ NMR (500 MHz, $\left.\mathrm{CDCl}_{3}\right): \delta 5.34(\mathrm{X}$ of $\mathrm{ABX}, 1 \mathrm{H}, \mathrm{J}=1.19,8.15 \mathrm{~Hz}), 4.52(\mathrm{~m}, 1 \mathrm{H}), 3.83$ (m, 1H), 3.81 (br s, OH), 3.49 (A of ABX, 1H, J=8.61, 16.70 Hz), 3.46 (A of ABX, 1H, J=8.15, $11.44 \mathrm{~Hz}$ ), 3.39 (B of ABX, 1H, J=1.28, 16.70 Hz), 3.36 (B of ABX, 1H, J=1.28, 11.44 Hz), 1.60 
$(\mathrm{m}, 3 \mathrm{H}), 1.39(\mathrm{~m}, 1 \mathrm{H}), 1.31(\mathrm{~s}, 3 \mathrm{H}), 1.29(\mathrm{~s}, 3 \mathrm{H}), 1.05(\mathrm{~d}, 3 \mathrm{H}, \mathrm{J}=7.05 \mathrm{~Hz}), 0.96(\mathrm{t}, 9 \mathrm{H}, \mathrm{J}=8.06$ $\mathrm{Hz}), 0.93$ (t, 9H, J=8.00 Hz), $0.91(\mathrm{~d}, 3 \mathrm{H}, \mathrm{J}=6.50 \mathrm{~Hz}), 0.87$ (d, 3H, J=6.50 Hz), 0.62 (q, 6H, $\mathrm{J}=8.00 \mathrm{~Hz}$ ), $0.60(\mathrm{q}, 6 \mathrm{H}, \mathrm{J}=8.06 \mathrm{~Hz}) .{ }^{13} \mathrm{C} \mathrm{NMR}\left(400 \mathrm{MHz}, \mathrm{CDCl}_{3}\right): \delta 205.5,171.9,76.9,76.6$, $72.8,72.4,67.3,44.3,43.8,39.5,30.2,28.5,26.6,25.0,23.9,22.5,11.8,7.4,7.3,6.9$, 5.4. IR $\left(\mathrm{cm}^{-1}\right): 3476,1689$. $[\alpha]_{\mathrm{D}}=-210(\mathrm{c} 0.64, \mathrm{EtOH})$. HRMS m/z calc'd for $\mathrm{C}_{28} \mathrm{H}_{57} \mathrm{NO}_{4} \mathrm{~S}_{2} \mathrm{Si}_{2} \mathrm{Na}^{+}$: 614.3159; found: 614.3152 .

Table 1, entry 9 :

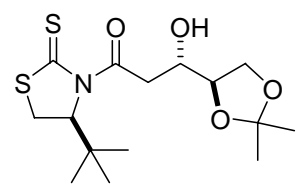

${ }^{1} \mathrm{H}$ NMR $\left(500 \mathrm{MHz}, \mathrm{CDCl}_{3}\right): \delta 5.33(\mathrm{X}$ of $\mathrm{ABX}, 1 \mathrm{H}, \mathrm{J}=8.13 \mathrm{~Hz}), 4.09(\mathrm{~m}, 1 \mathrm{H}), 4.05(\mathrm{~m}$, $1 \mathrm{H}), 3.95(\mathrm{~m}, 2 \mathrm{H}), 3.57$ (A of ABX, 1H, J=9.23, $17.58 \mathrm{~Hz}$ ), 3.54 (A of ABX, 1H, J=8.13, 11.76 $\mathrm{Hz}), 3.47$ (B of ABX, 1H, J=2.75, $17.58 \mathrm{~Hz}), 3.29(\mathrm{~d}, \mathrm{OH}, \mathrm{J}=4.61 \mathrm{~Hz}), 3.11(\mathrm{~B}$ of $\mathrm{ABX}, 1 \mathrm{H}$, $\mathrm{J}=11.76 \mathrm{~Hz}), 1.39(\mathrm{~s}, 3 \mathrm{H}), 1.33(\mathrm{~s}, 3 \mathrm{H}), 1.02(\mathrm{~s}, 9 \mathrm{H}) .{ }^{13} \mathrm{C} \mathrm{NMR}\left(400 \mathrm{MHz}, \mathrm{CDCl}_{3}\right): \delta 205.3$, $172.9,109.8,77.8,72.3,70.0,67.1,41.2,38.1,30.8,30.7,27.2,26.9,25.8,25.4 . \quad$ IR $\left(\mathrm{cm}^{-1}\right)$ : 3452, 1682. $[\alpha]_{\mathrm{D}}=289$ (c 1., EtOH). HRMS m/z calc'd for $\mathrm{C}_{15} \mathrm{H}_{25} \mathrm{NO}_{4} \mathrm{~S}_{2} \mathrm{Na}^{+}: 370.1117$; found: 370.1128 .

Table 1, entry 10:

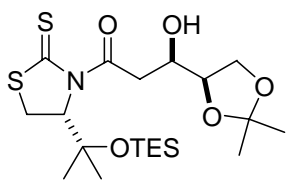

${ }^{1} \mathrm{H}$ NMR $\left(500 \mathrm{MHz}, \mathrm{CDCl}_{3}\right): \delta 5.33(\mathrm{X}$ of ABX, 1H, J=8.02 Hz), $4.20(\mathrm{~m}, 1 \mathrm{H}), 4.15(\mathrm{~m}$, $1 \mathrm{H}), 4.05(\mathrm{~m}, 1 \mathrm{H}), 3.91(\mathrm{~m}, 1 \mathrm{H}), 3.72(\mathrm{~A}$ of $\mathrm{ABX}, 1 \mathrm{H}, \mathrm{J}=9.45,16.92 \mathrm{~Hz}), 3.51(\mathrm{~A}$ of $\mathrm{ABX}, 1 \mathrm{H}$, $\mathrm{J}=8.24,11.54 \mathrm{~Hz}$ ), 3.44 (B of ABX, 1H, J=11.54 Hz), 3.32 (B of ABX, 1H, J=3.30, 16.92 Hz), 3.29 (d, OH, J=6.15 Hz), 1.47 (s, 3H), 1.39 (s, 3H), $1.34(\mathrm{~s}, 3 \mathrm{H}), 1.32$ (s, 3H), 0.97 (t, 9H, J=7.91 $\mathrm{Hz}), 0.64$ (q, 6H, J=7.91 Hz). ${ }^{13} \mathrm{C} \mathrm{NMR}\left(400 \mathrm{MHz}, \mathrm{CDCl}_{3}\right): \delta 206.0,172.2,109.9,77.7,72.6$, $68.9,65.6,41.1,30.3,28.3,26.6,26.5,25.4,7.3,6.8$. IR $\left(\mathrm{cm}^{-1}\right): 3445,1689 .[\alpha]_{\mathrm{D}}=-282(\mathrm{c}$ 2.57, EtOH). HRMS m/z calc'd for $\mathrm{C}_{20} \mathrm{H}_{37} \mathrm{NO}_{5} \mathrm{~S}_{2} \mathrm{SiNa}^{+}$: 486.1775; found: 486.1796 . 


\section{Page S-13}

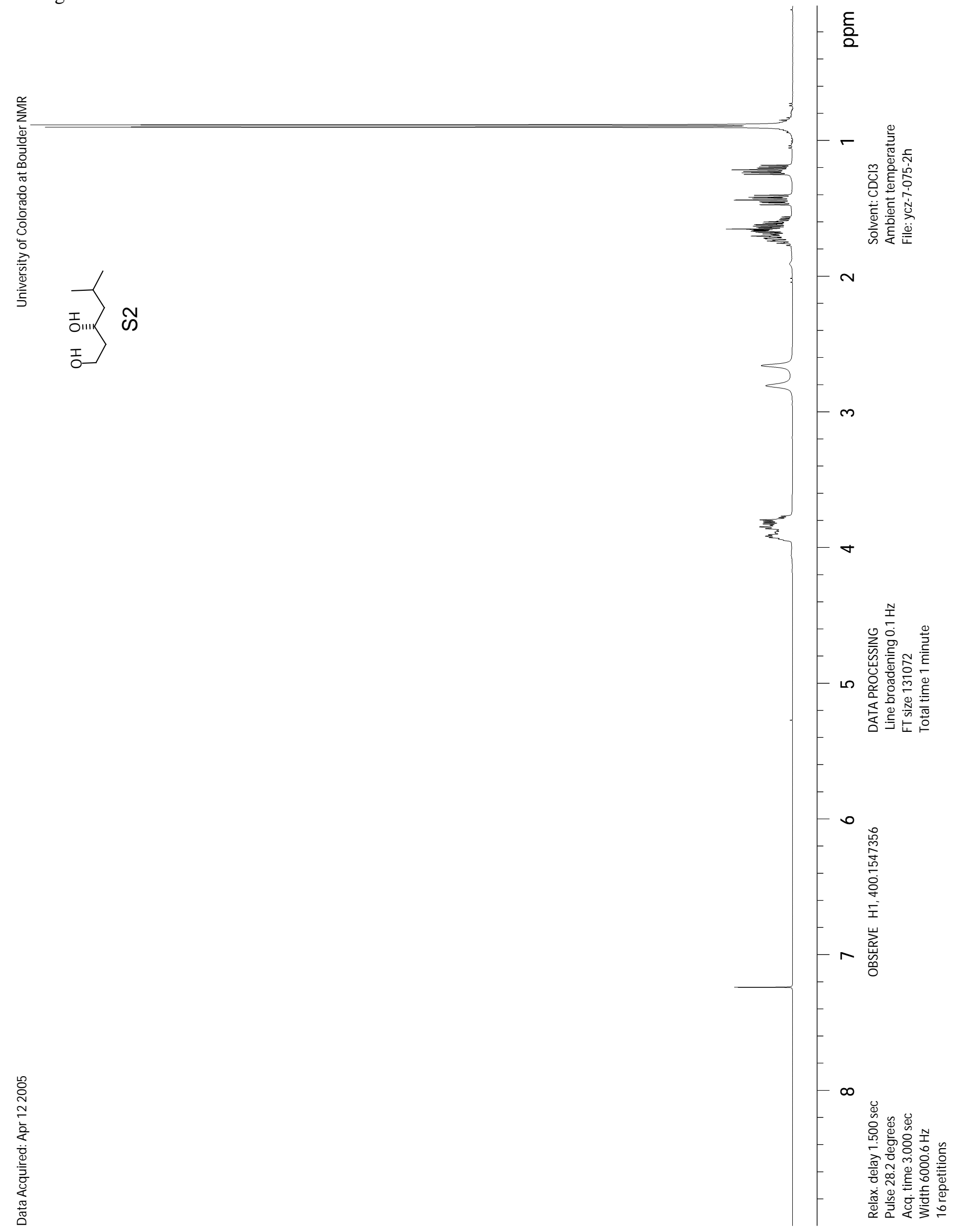


Page S-14

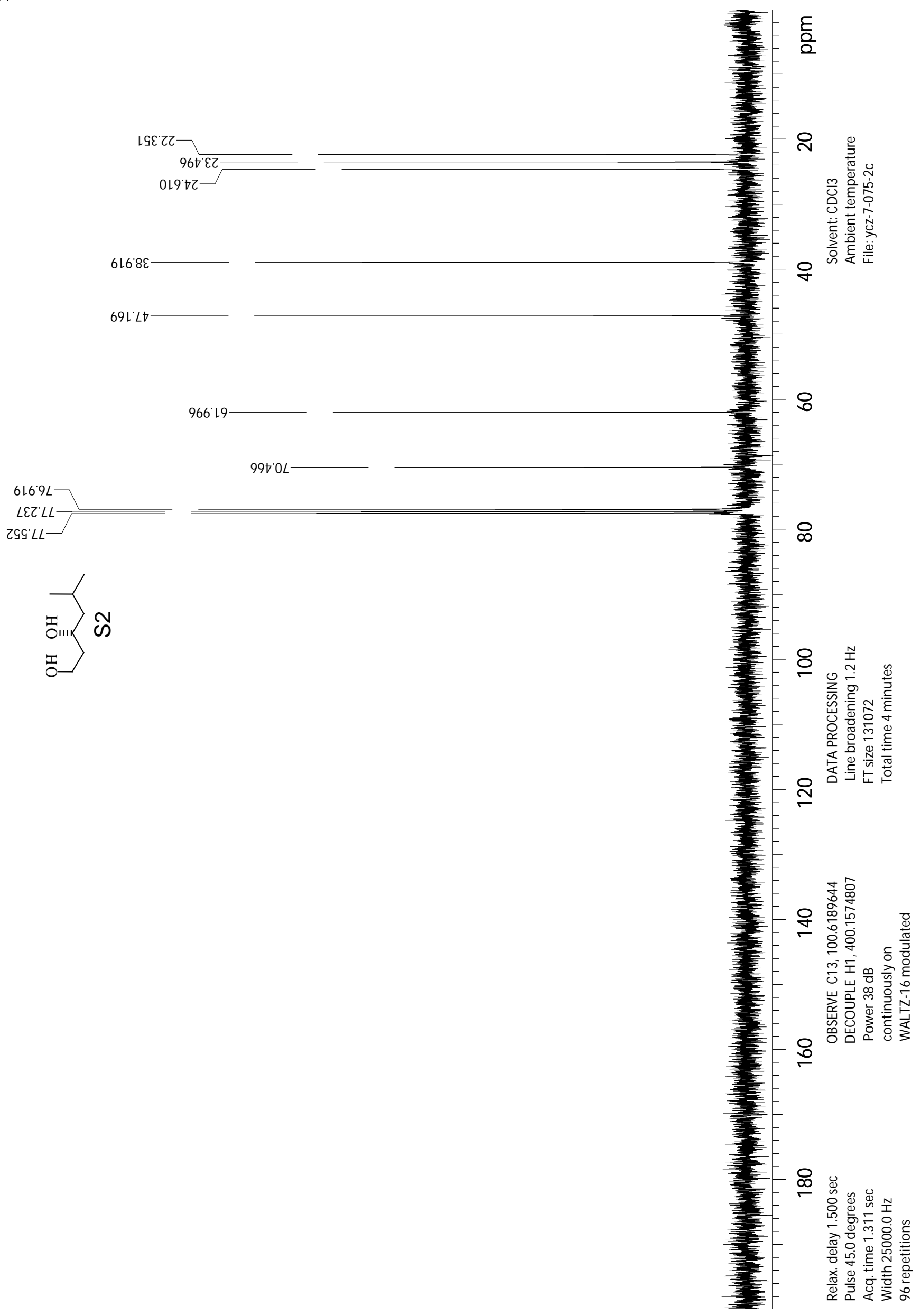


Page S-15

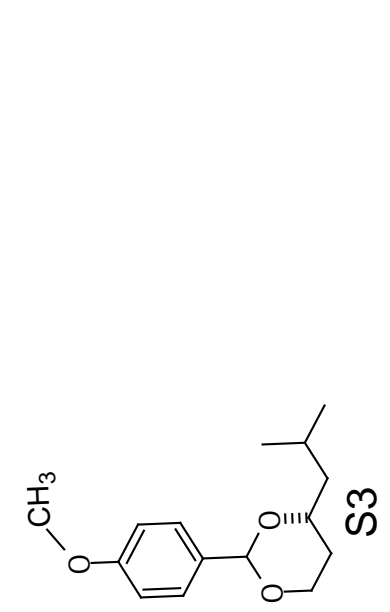

$t+\frac{\varepsilon}{2}$
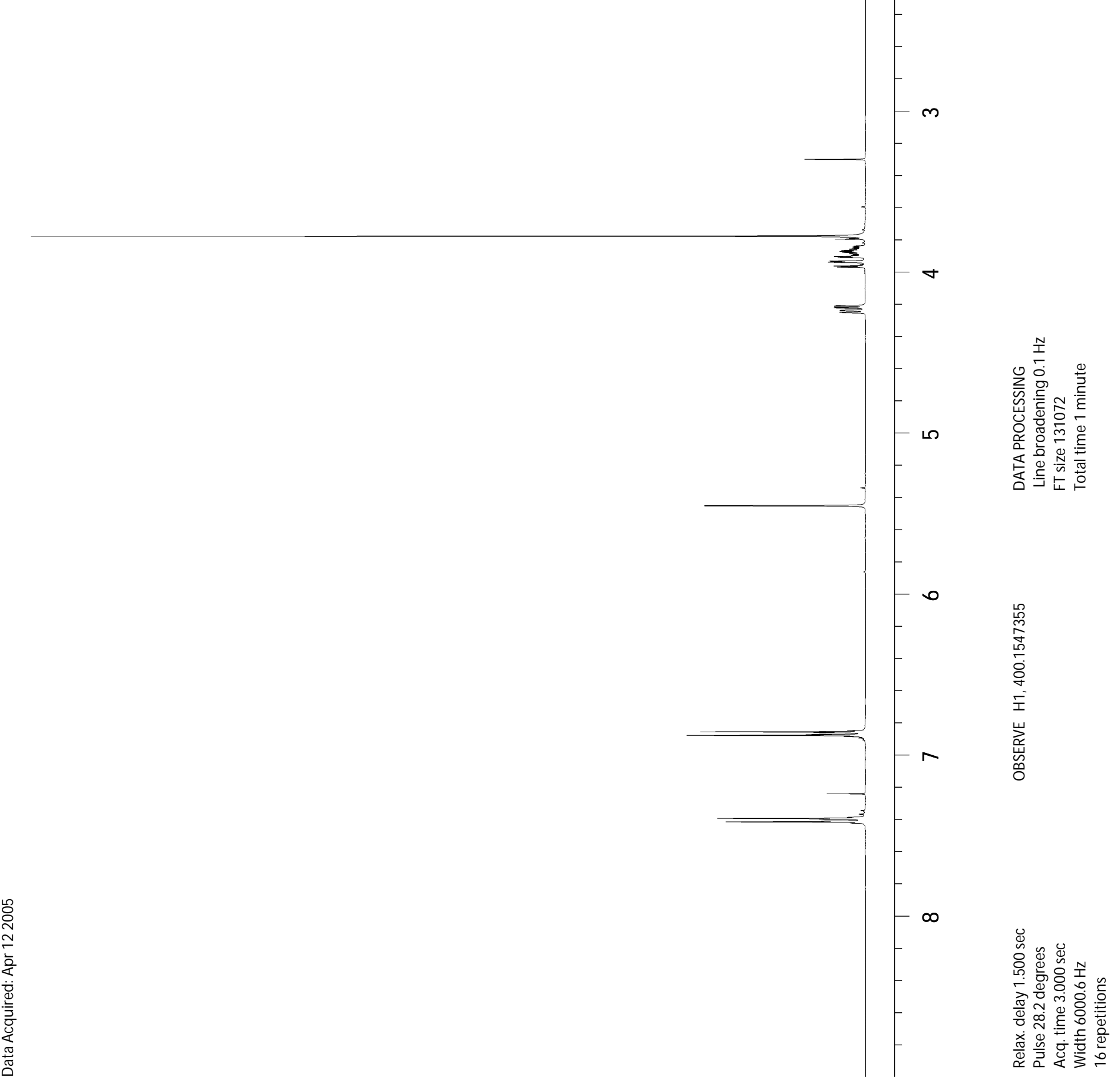
Page S-16

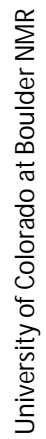
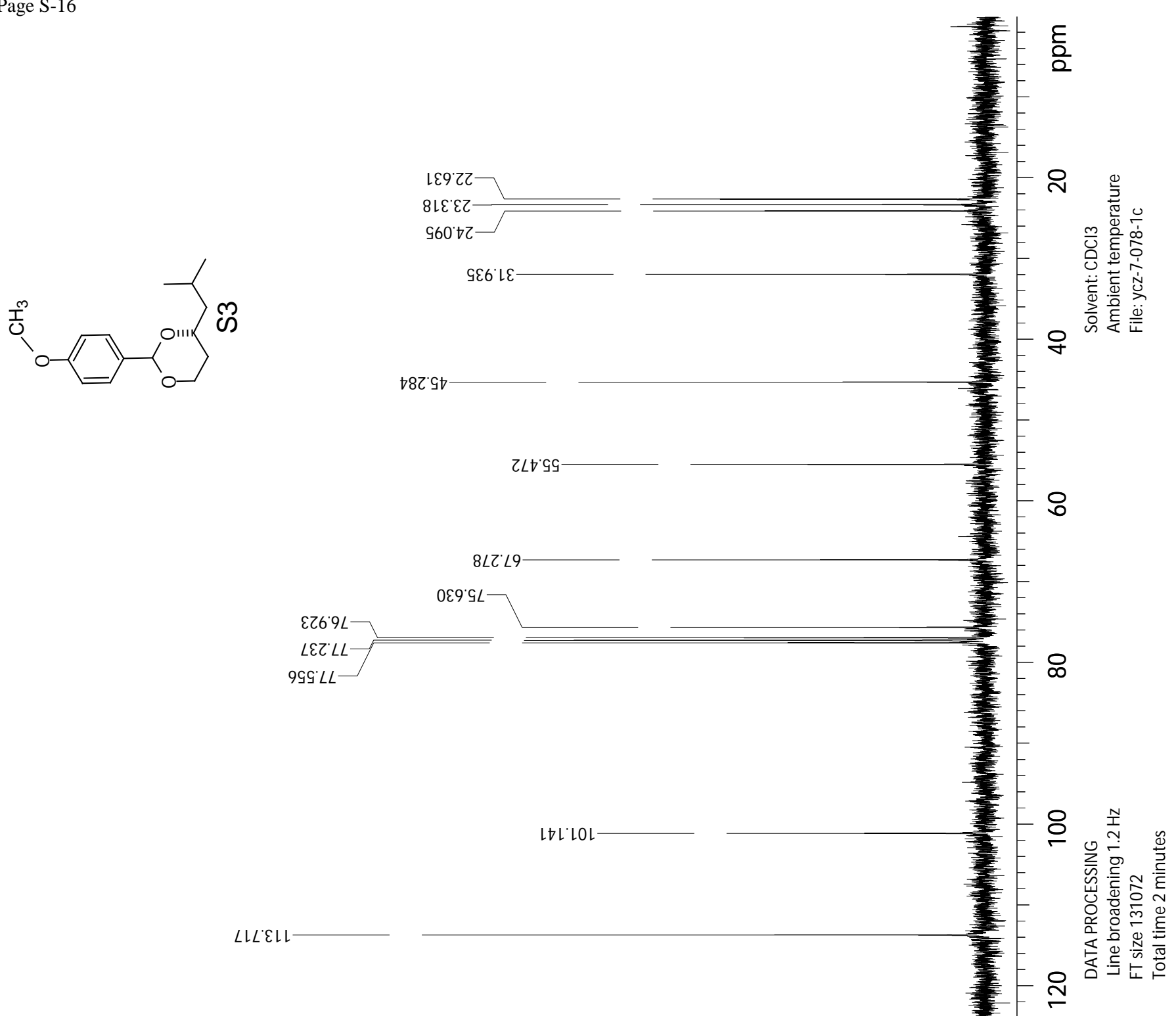

Stt' LZI

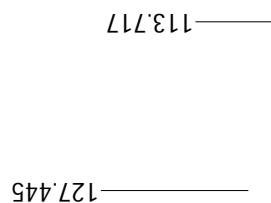

$06^{\circ} 6 \mathrm{SI}$

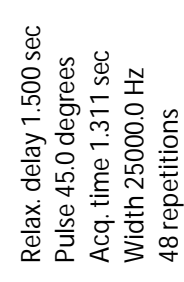


Page S-17

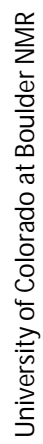

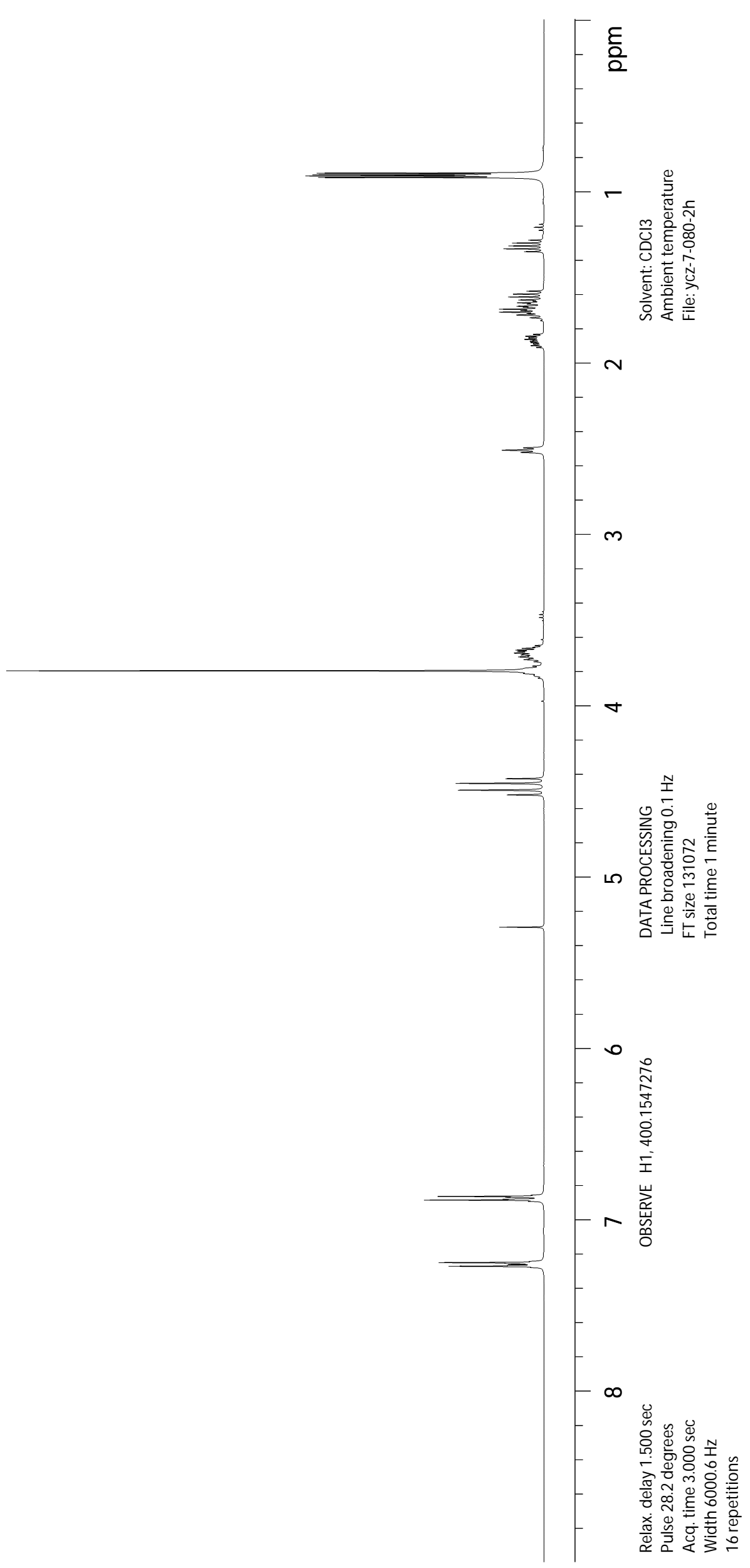


Page S-18

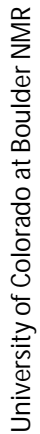

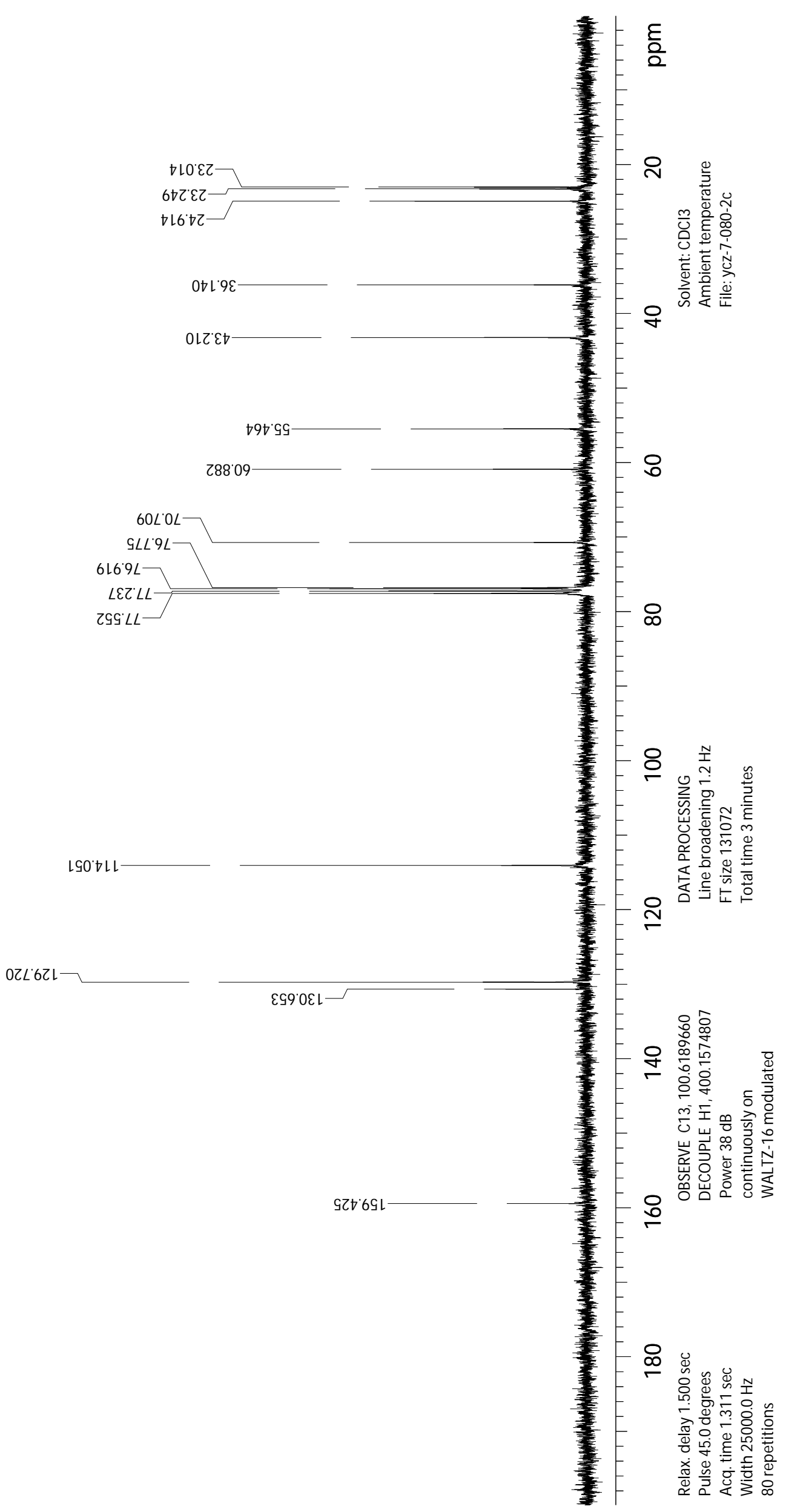


Page S-19

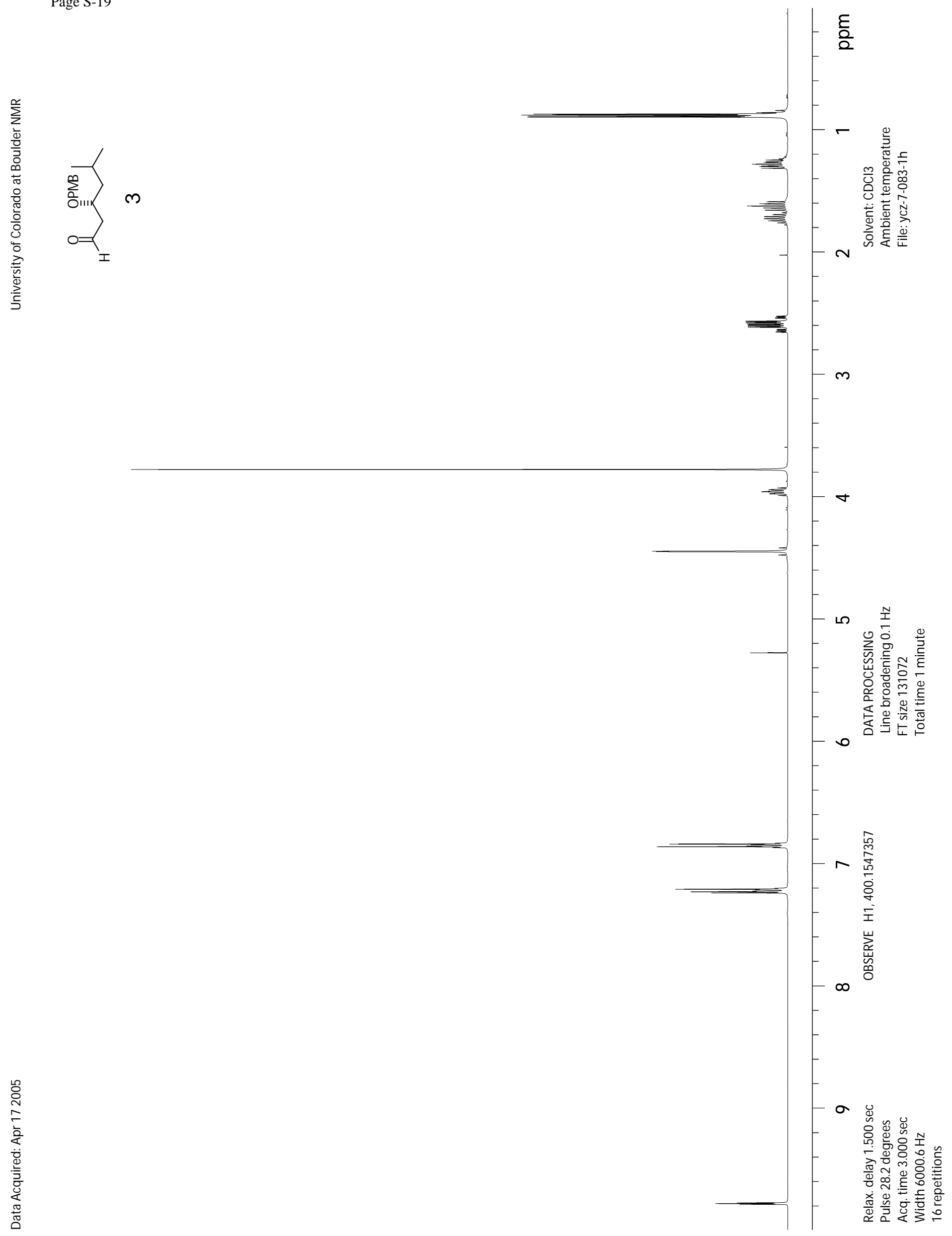


Page S-20
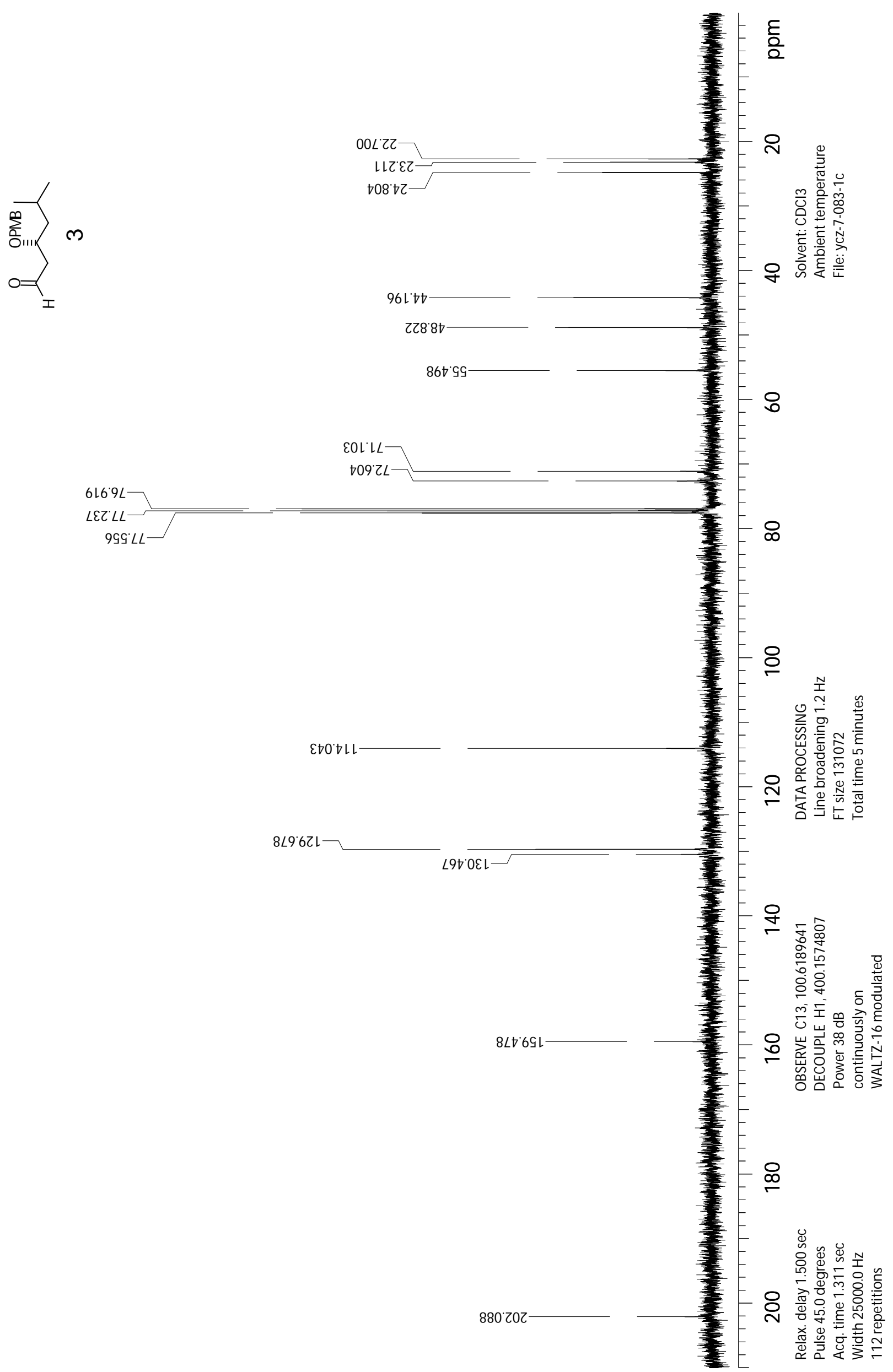
Page S-29

$\sum_{2}^{0}$
$\frac{0}{0}$
$\frac{0}{5}$
8
$\frac{1}{0}$
0
$\frac{0}{0}$
$\frac{0}{0}$
0
40
$\frac{1}{0}$
$\frac{5}{0}$
$\frac{1}{5}$
5
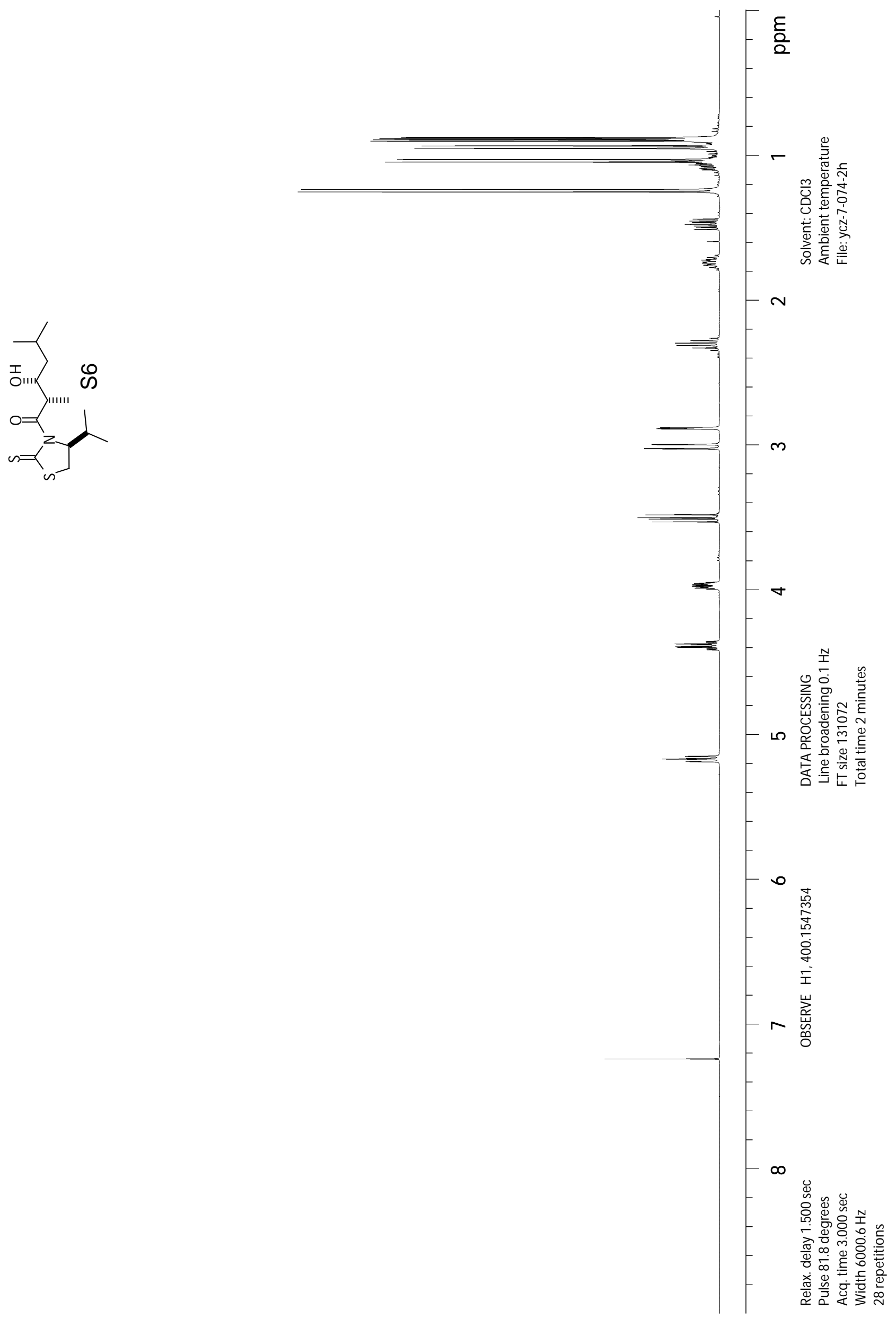
Page S-30
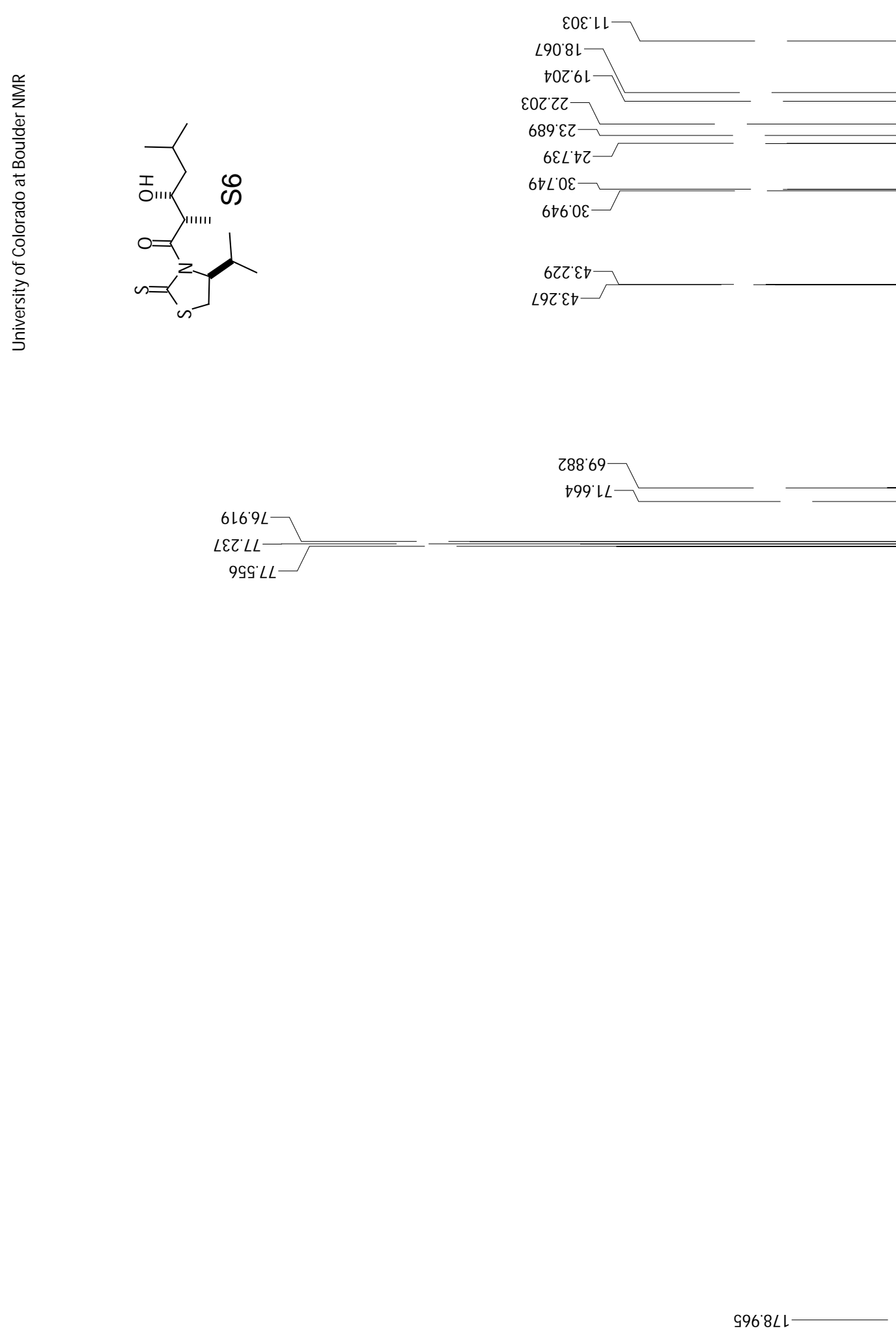

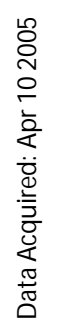

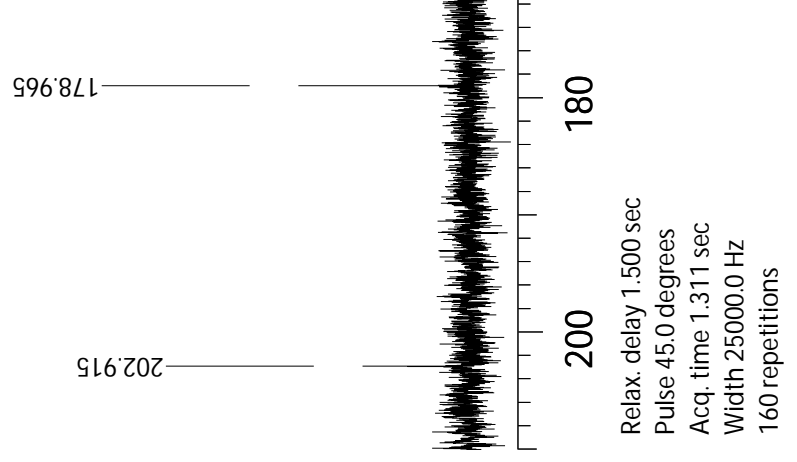


Page S-31

$\sum_{2}^{0}$
$\frac{0}{0}$
$\frac{0}{5}$
8
$\frac{1}{0}$
0
$\frac{0}{0}$
$\frac{0}{0}$
0
40
$\frac{1}{0}$
$\frac{5}{0}$
$\frac{1}{5}$
5

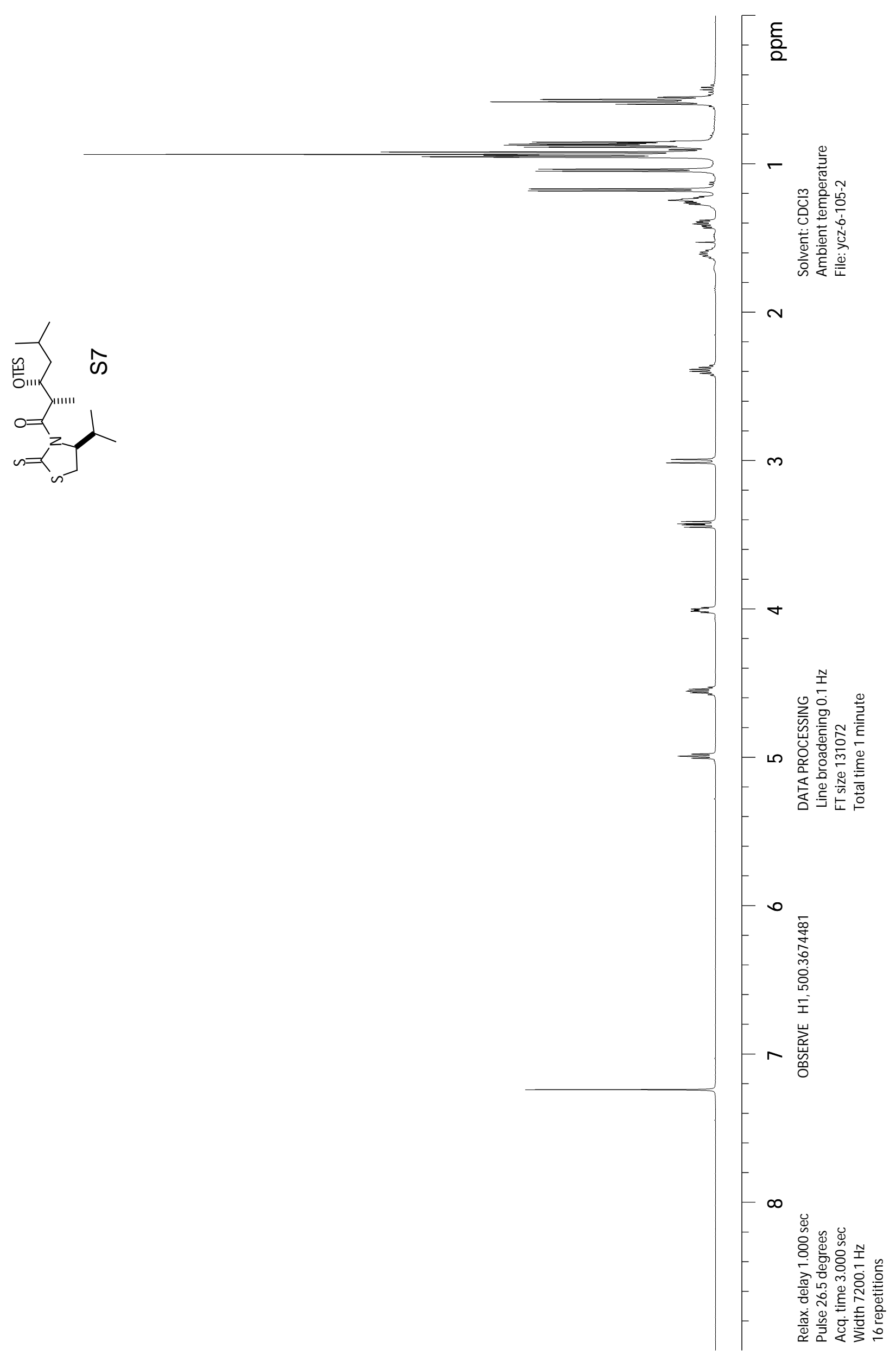


Page S-32

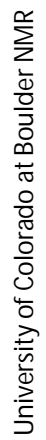
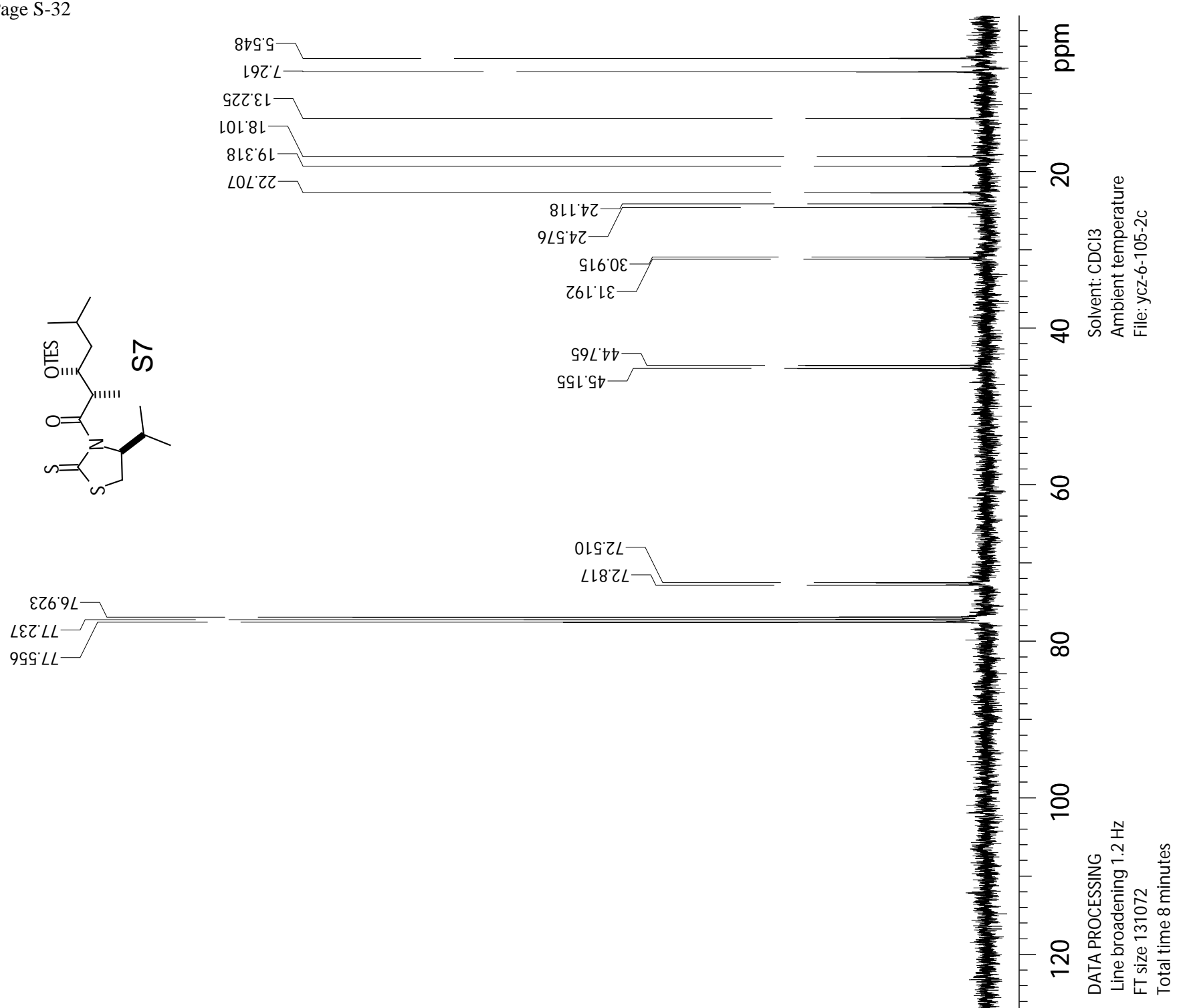
Page S-33

$\sum_{2}^{0}$
$\frac{0}{0}$
$\frac{0}{5}$
8
$\frac{1}{0}$
0
$\frac{0}{0}$
$\frac{0}{0}$
0
40
$\frac{1}{0}$
$\frac{5}{0}$
$\frac{1}{5}$
5

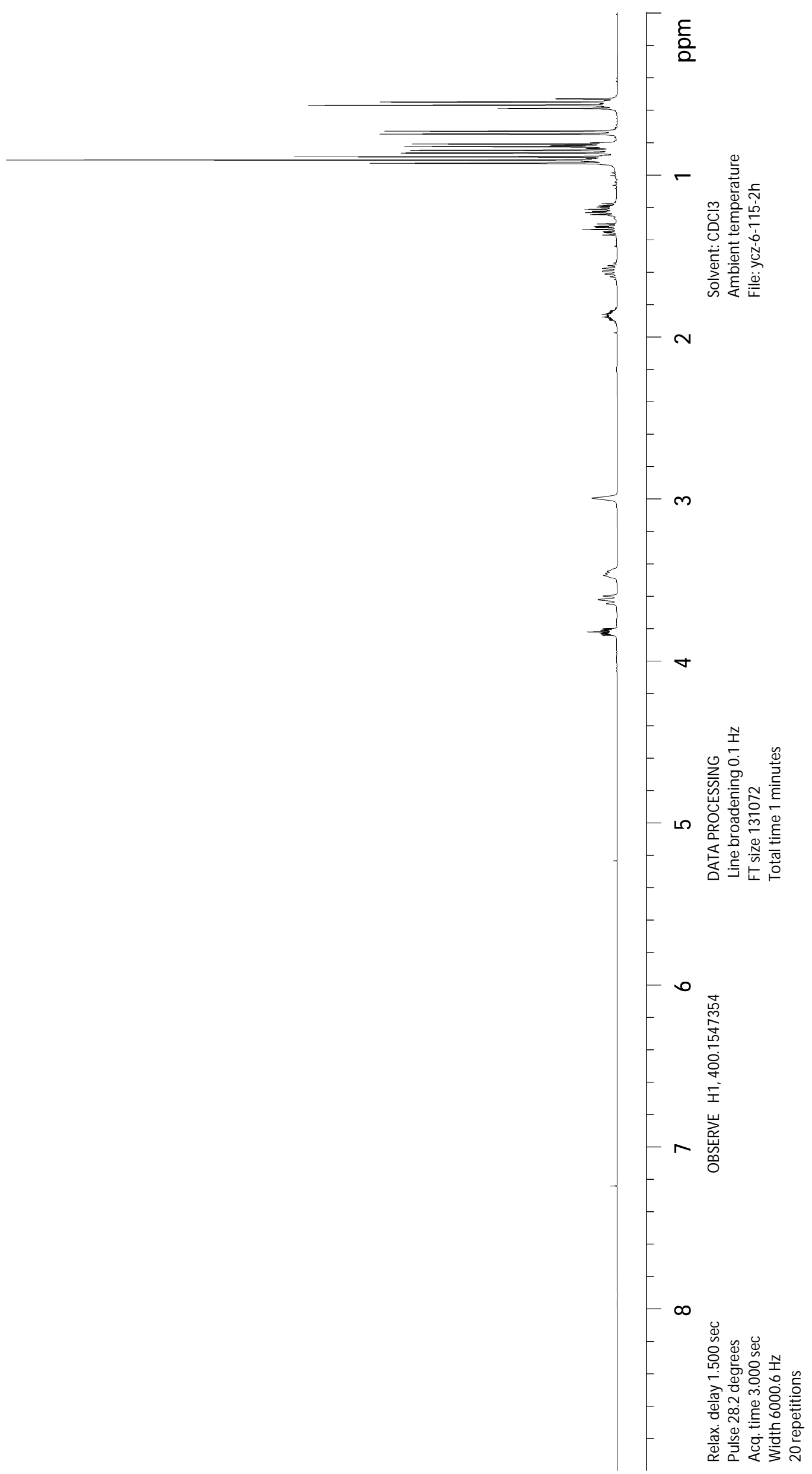


Page S-34

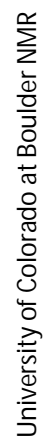
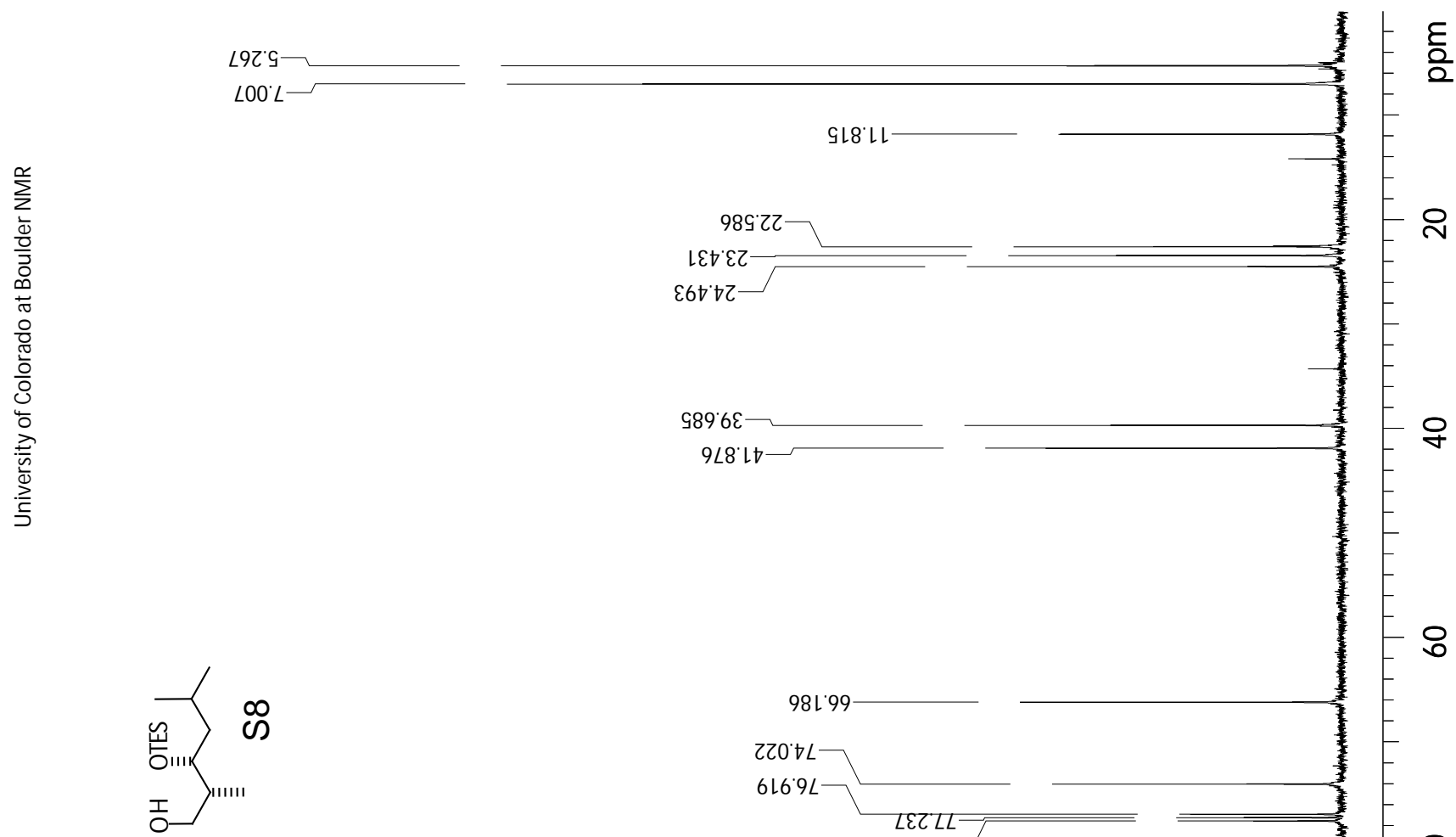

$589^{\circ} 6 \varepsilon$

ST8' IT

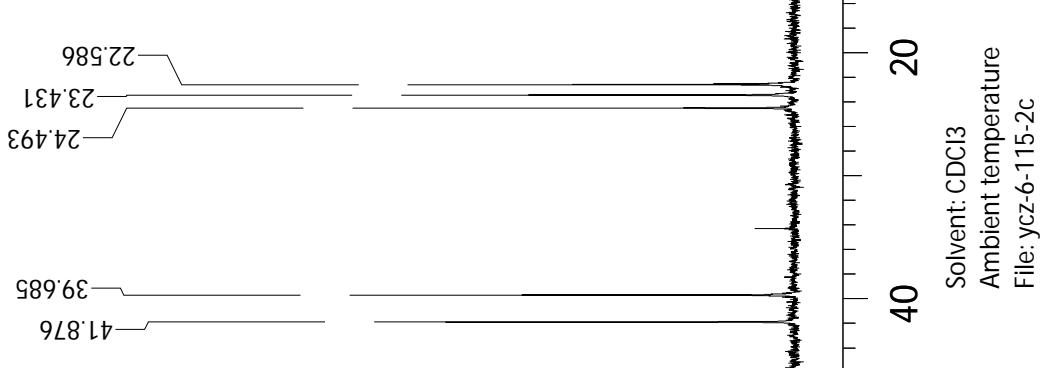

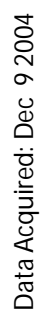

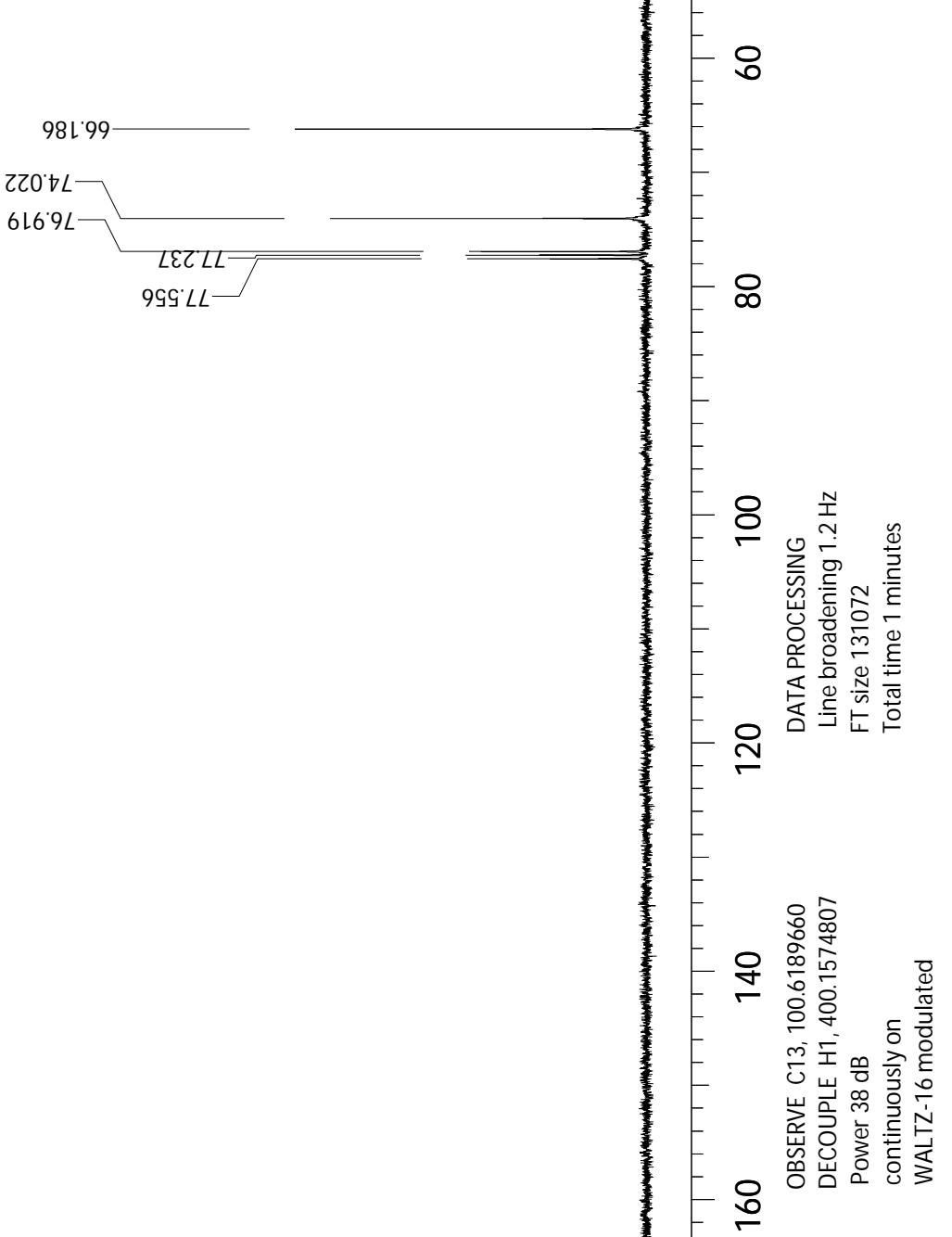


Page S-35

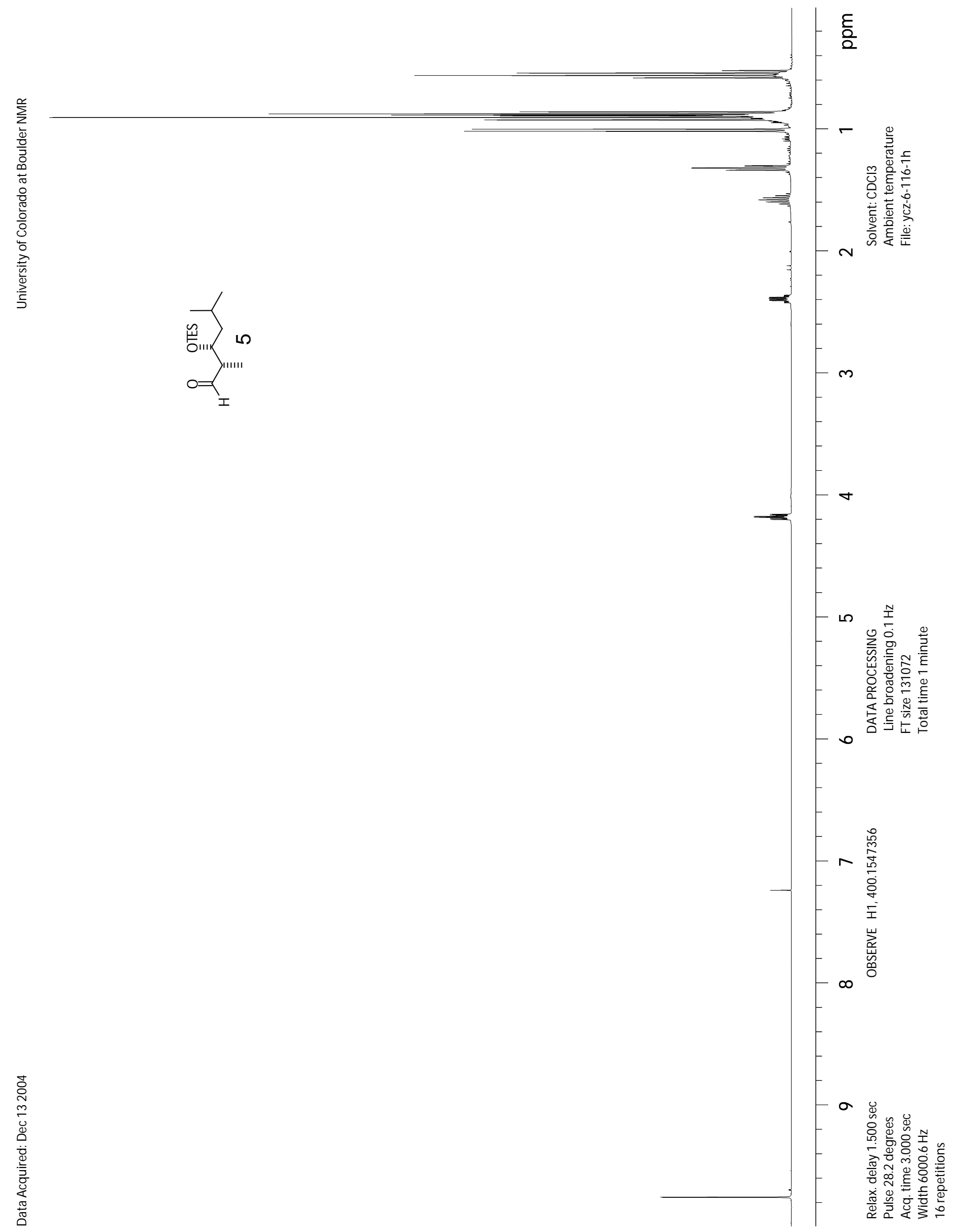


Page S-36

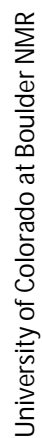
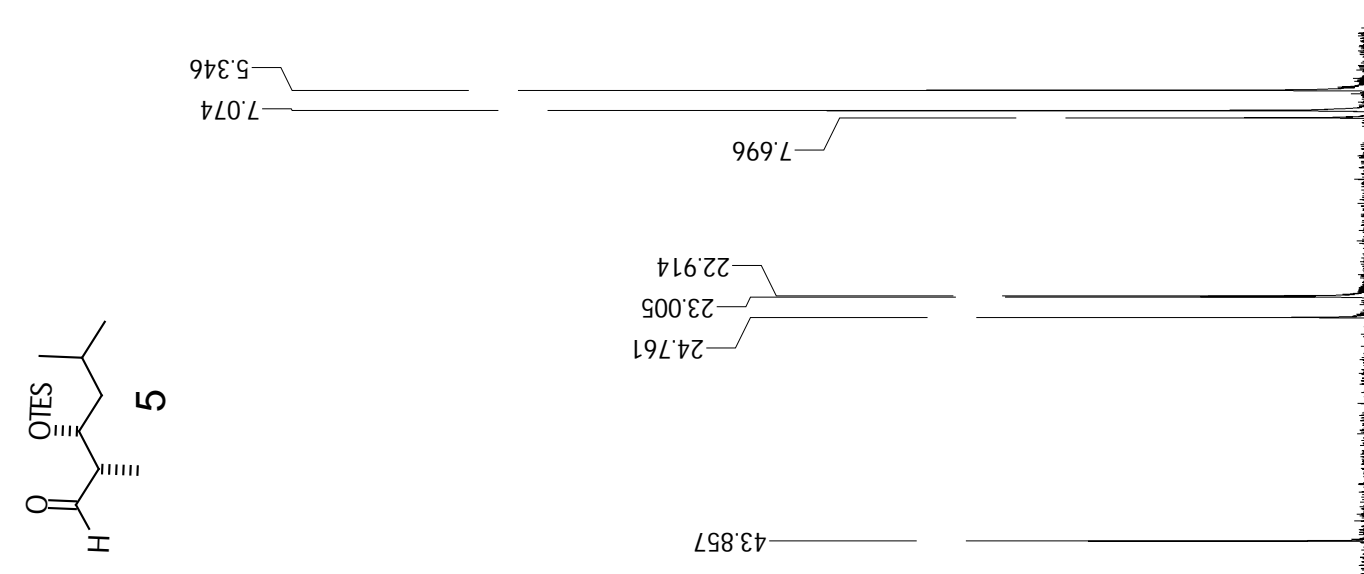

ํㅡㅇ

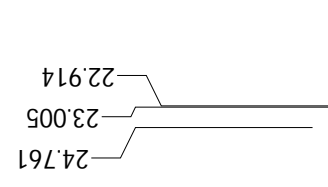

요

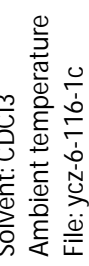

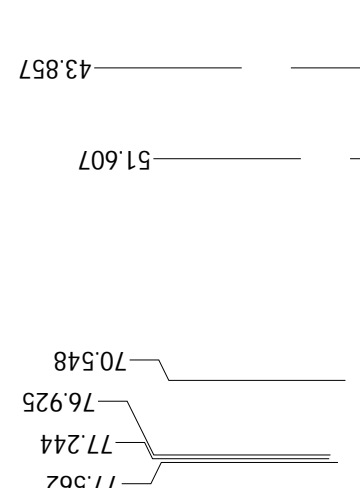

8

$\infty$

8

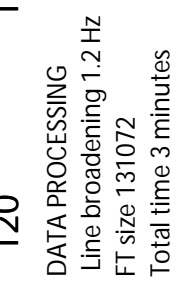


Page S-21

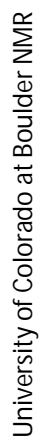
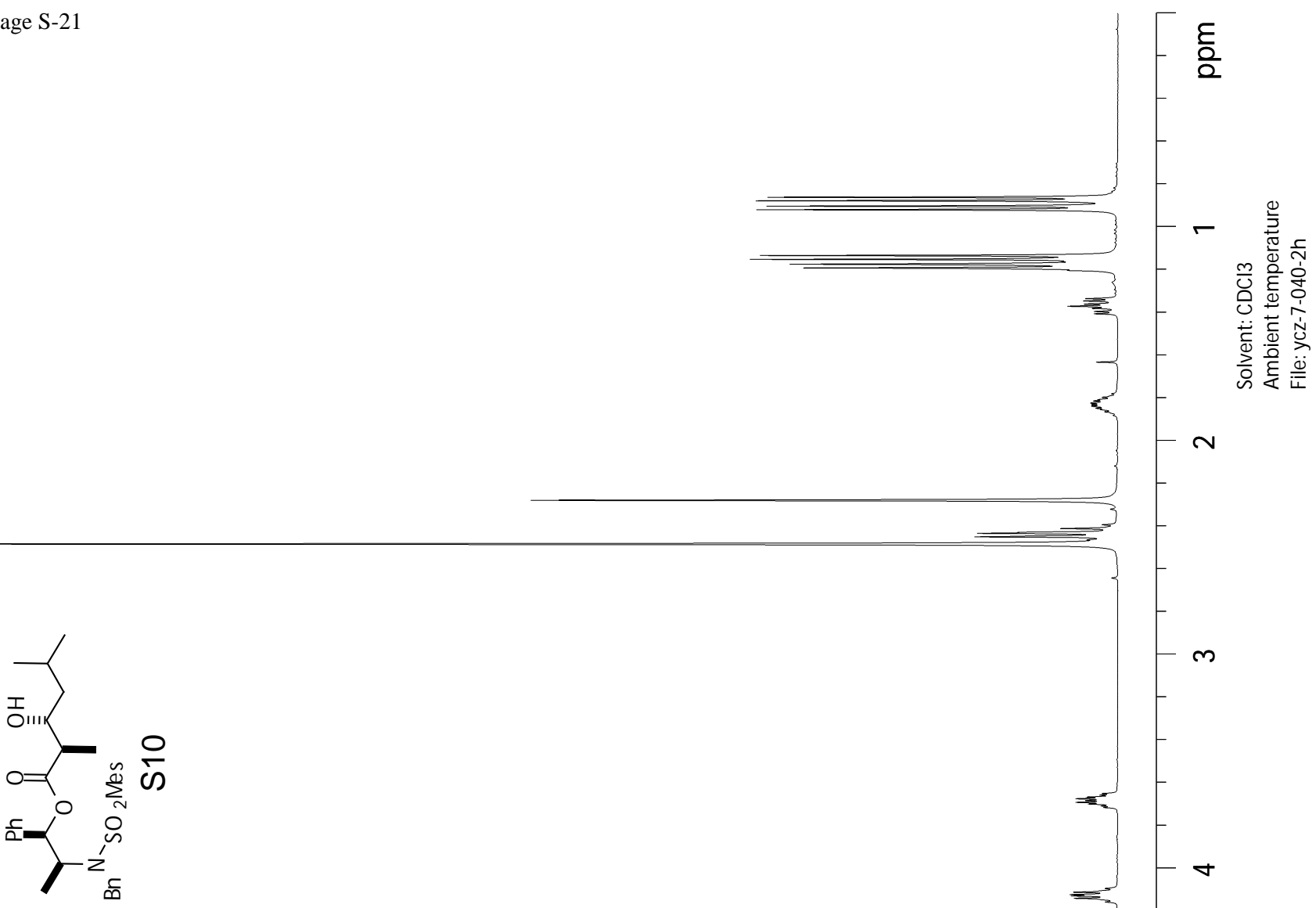

$\infty$

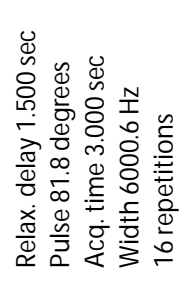


Page S-22

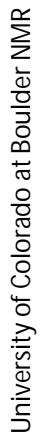

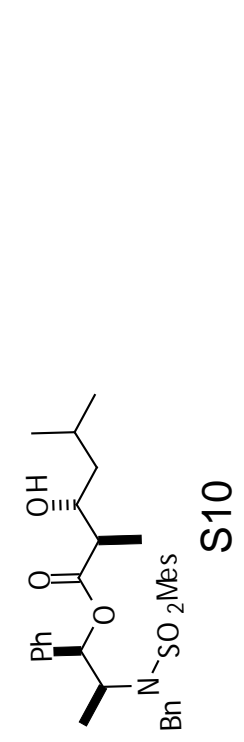

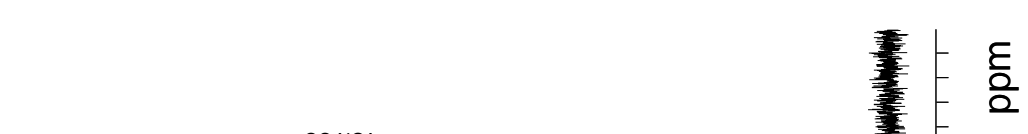
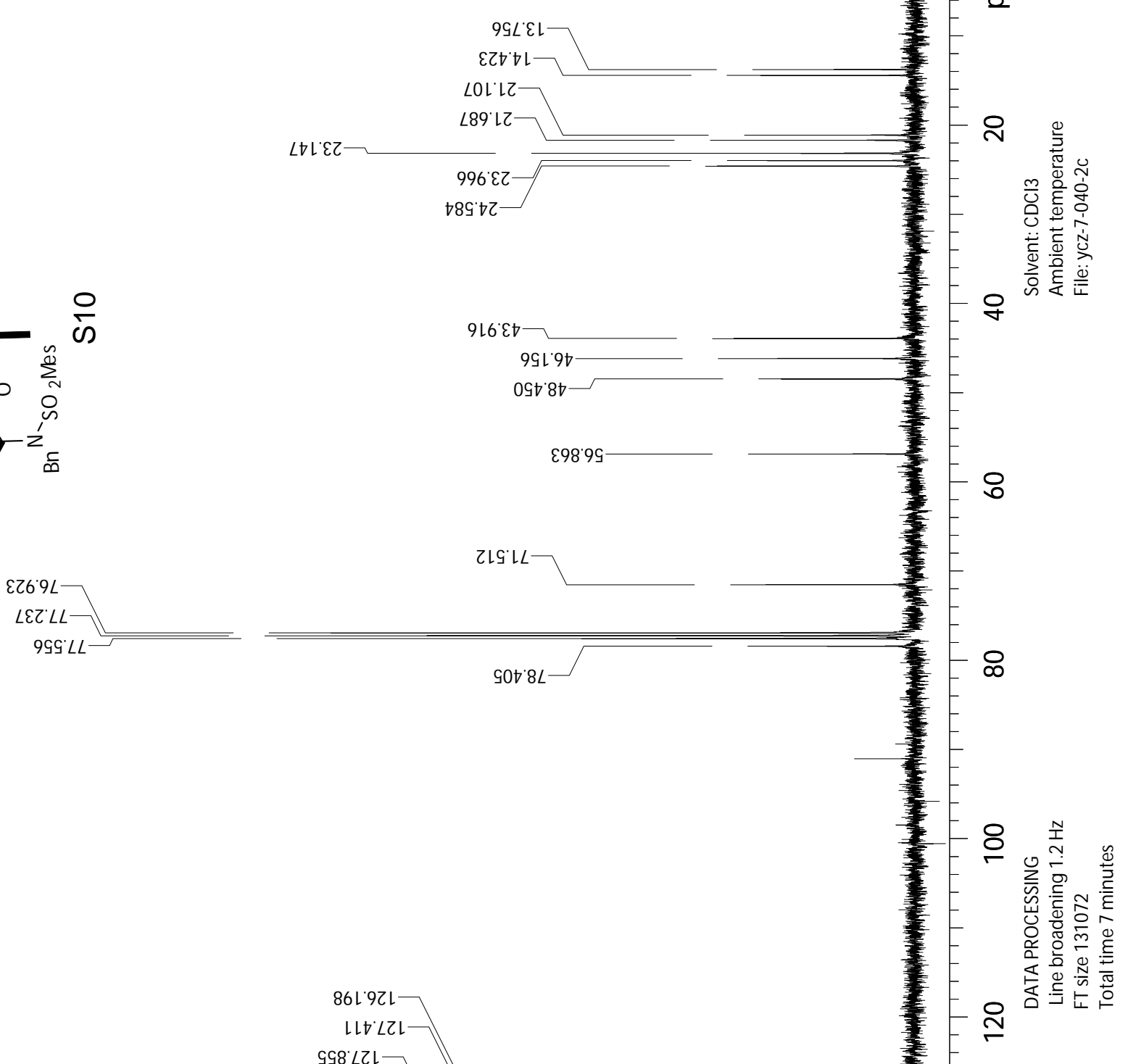
$821-$ 9ع9.8Zโ૬૪દ'ટદโLOع'8हL ८ع9'8\& I9t'0tI-
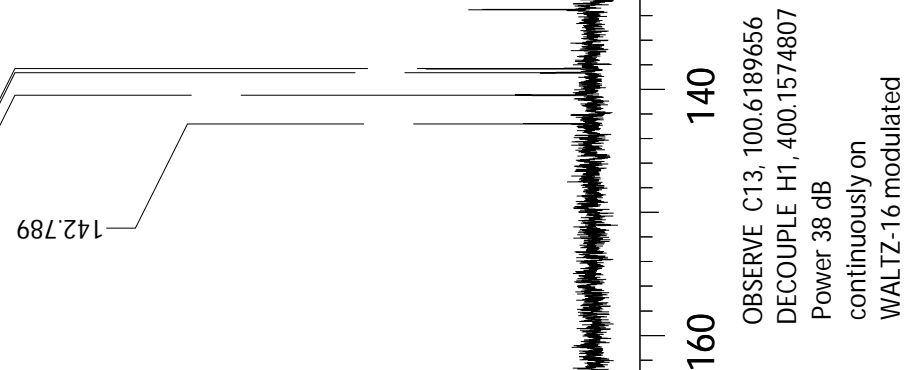
Page S-23

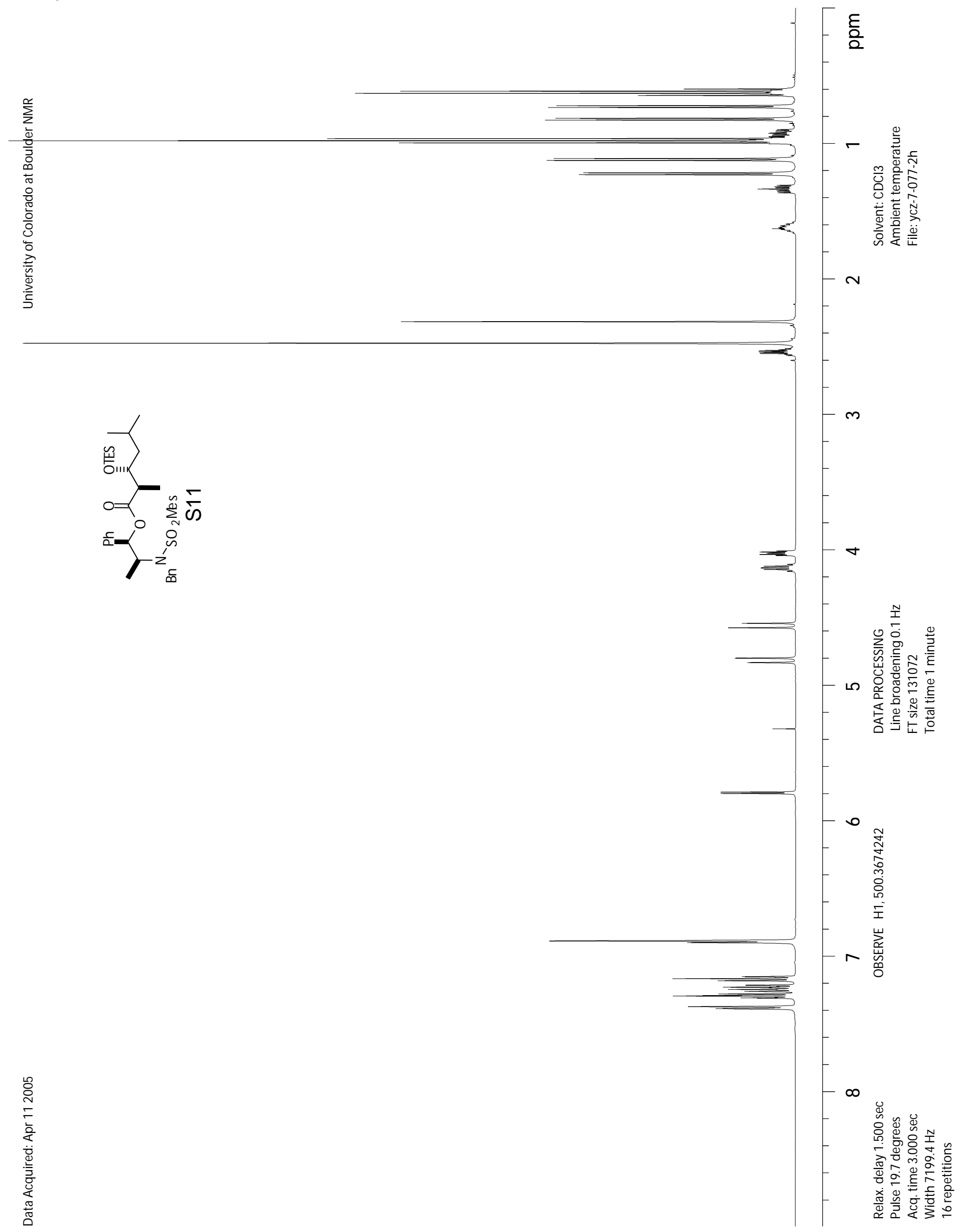


Page S-24

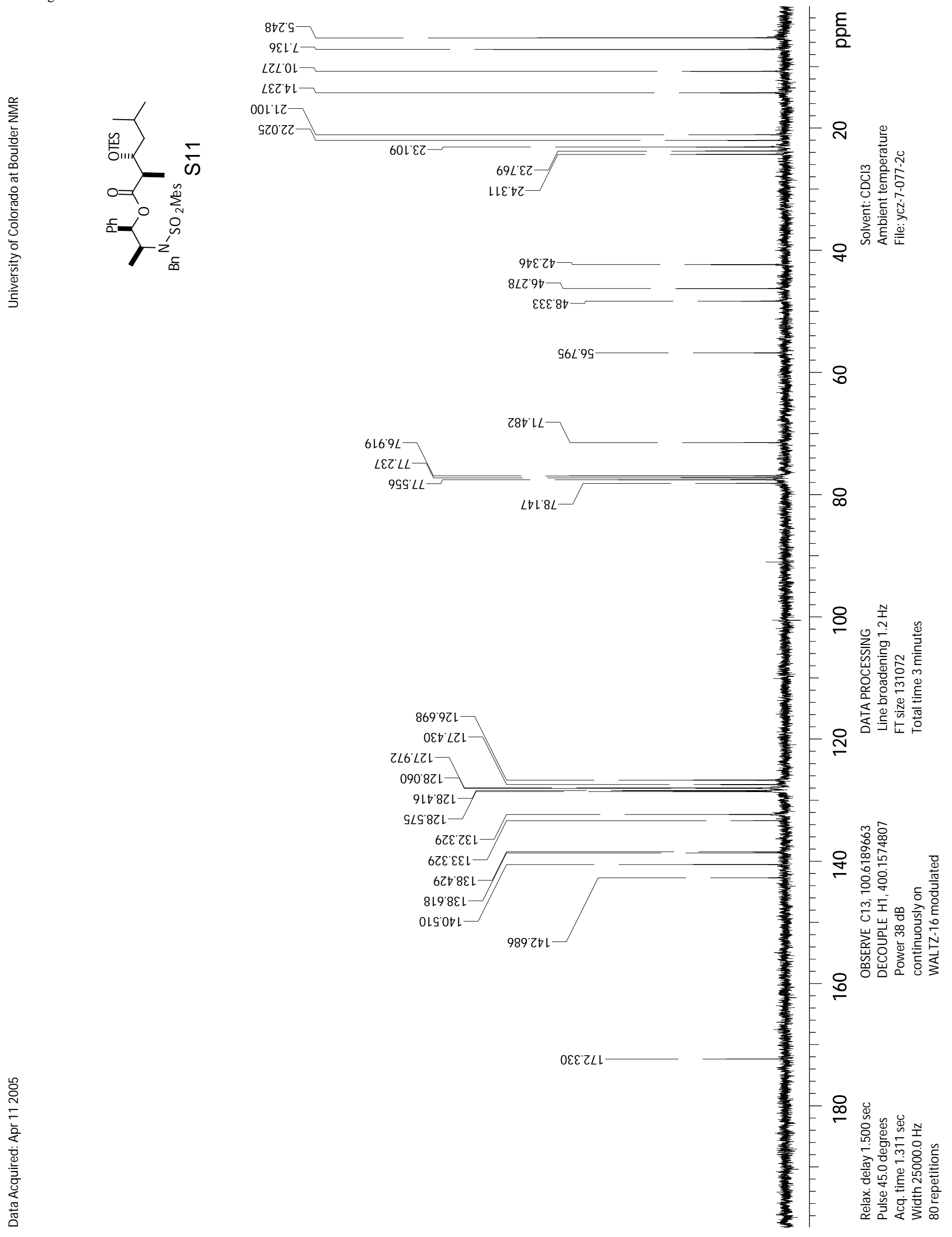


Page S-25

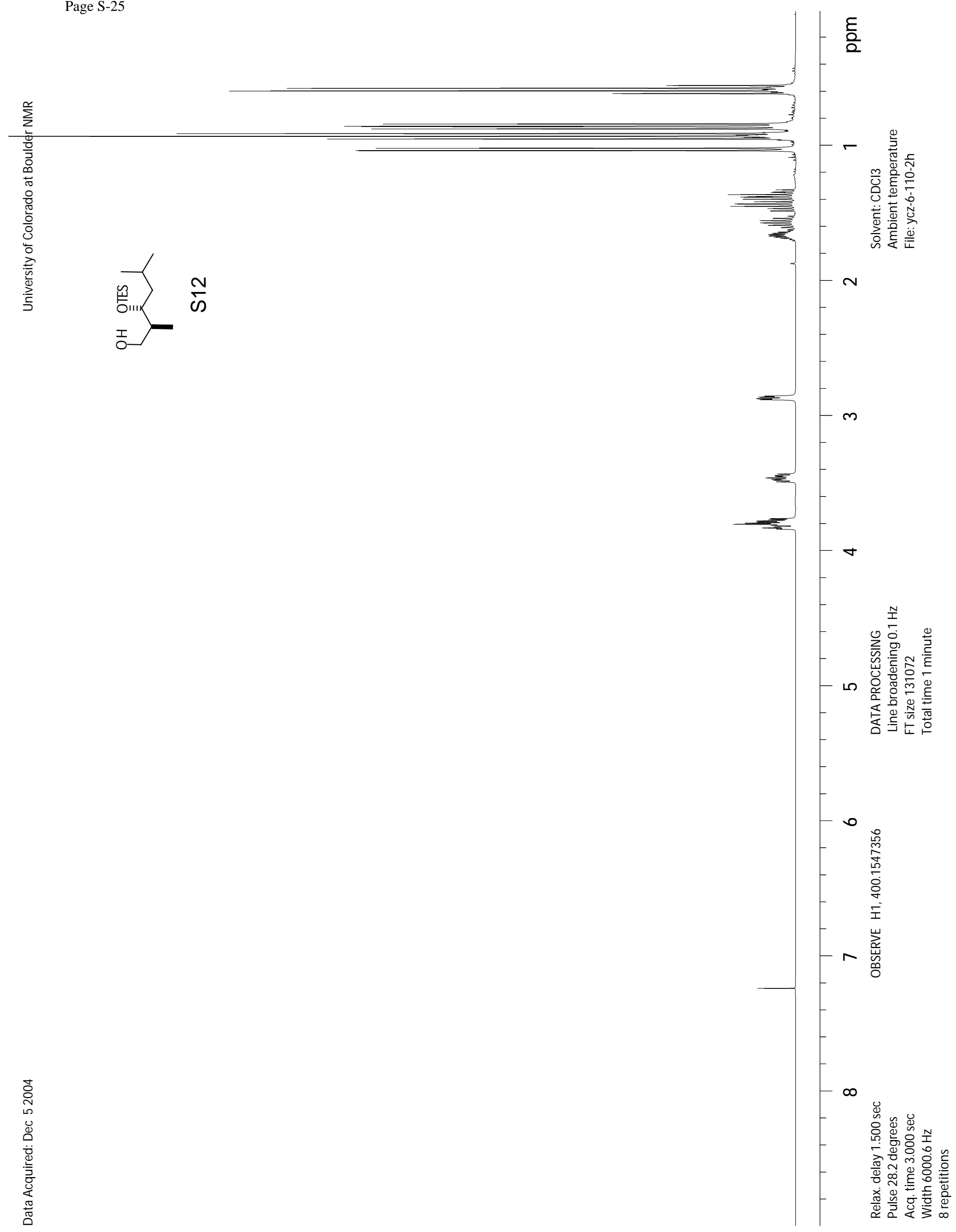


Page S-26

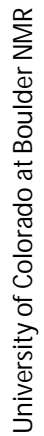

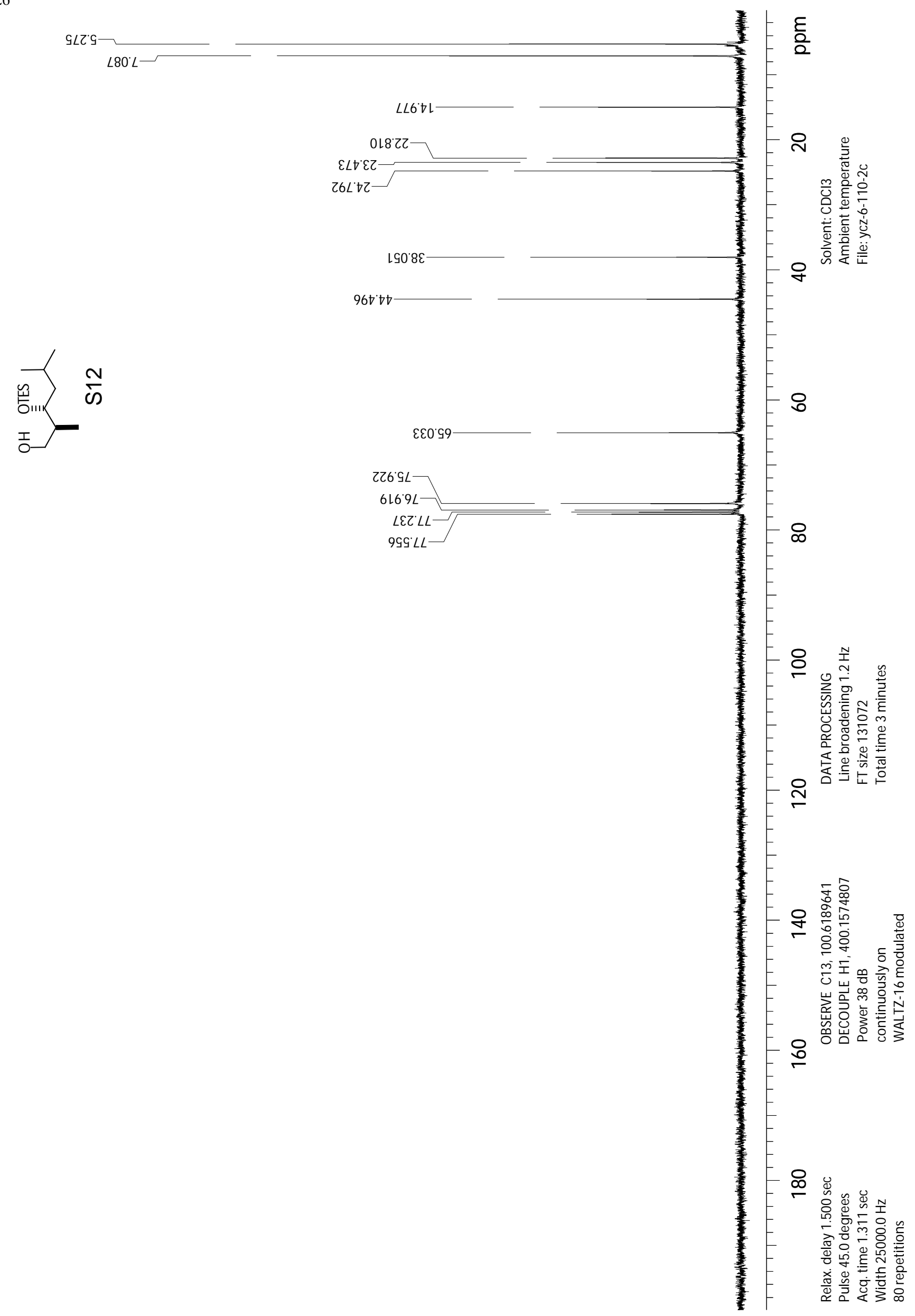


Page S-27
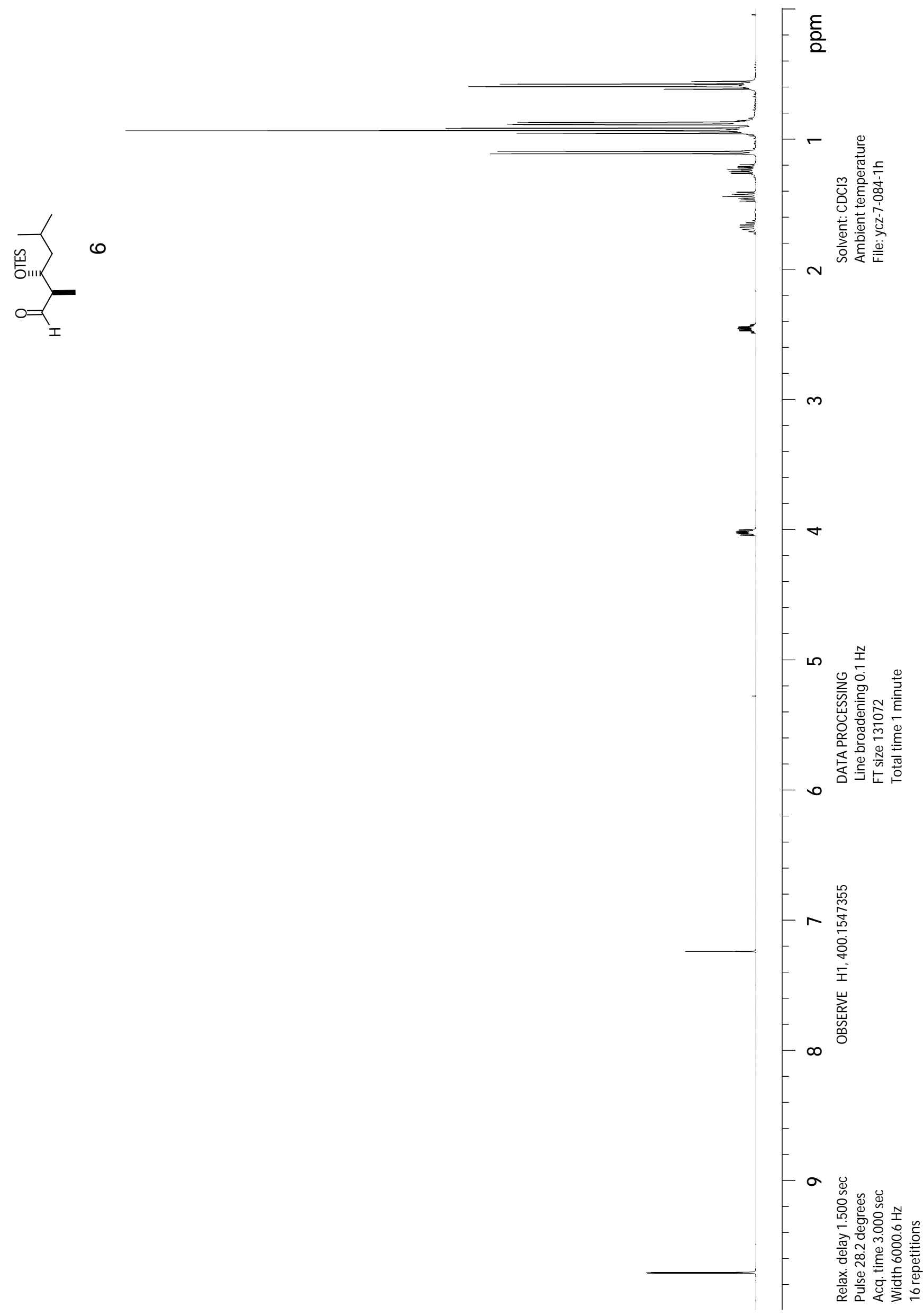
Page S-28

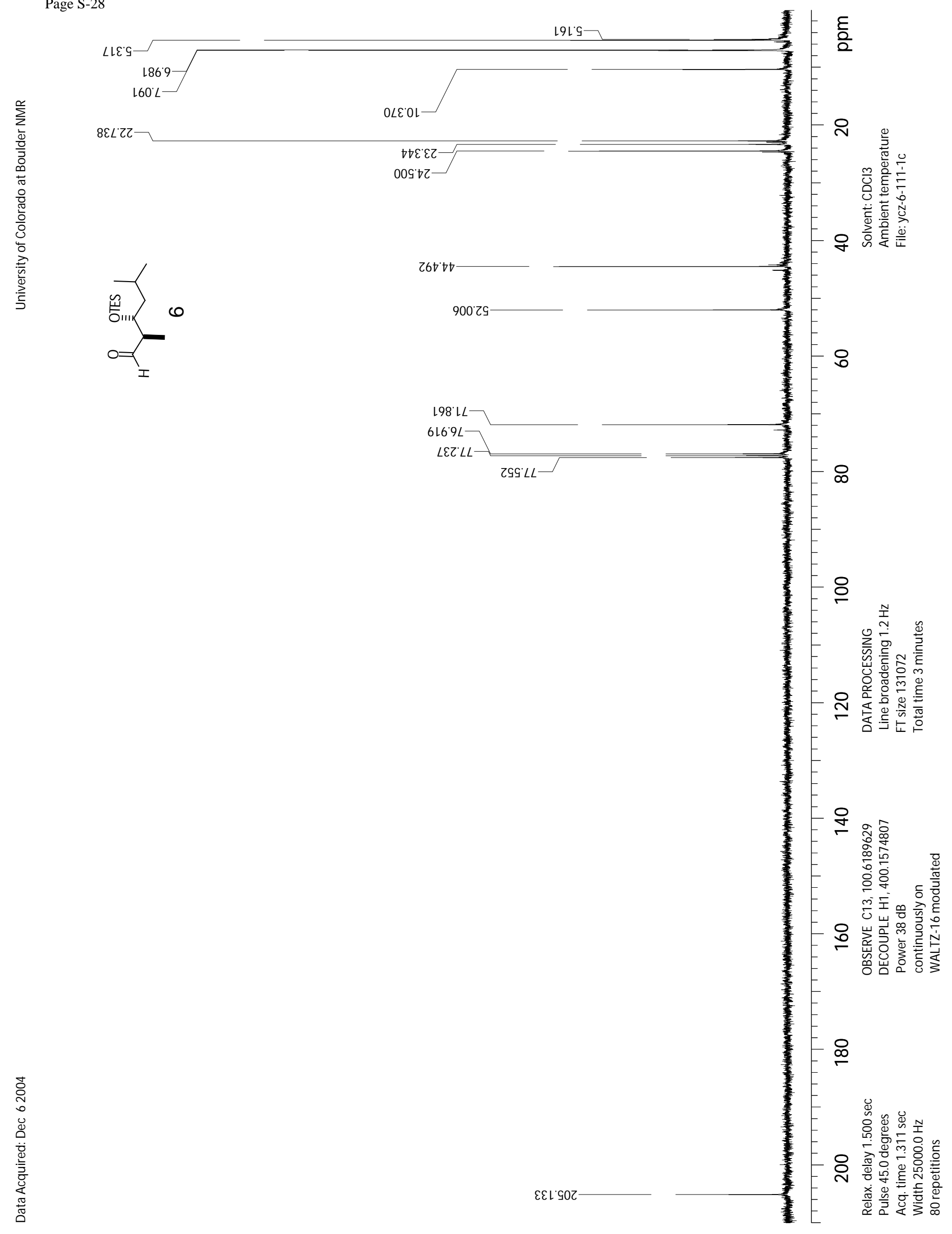


Page S-37

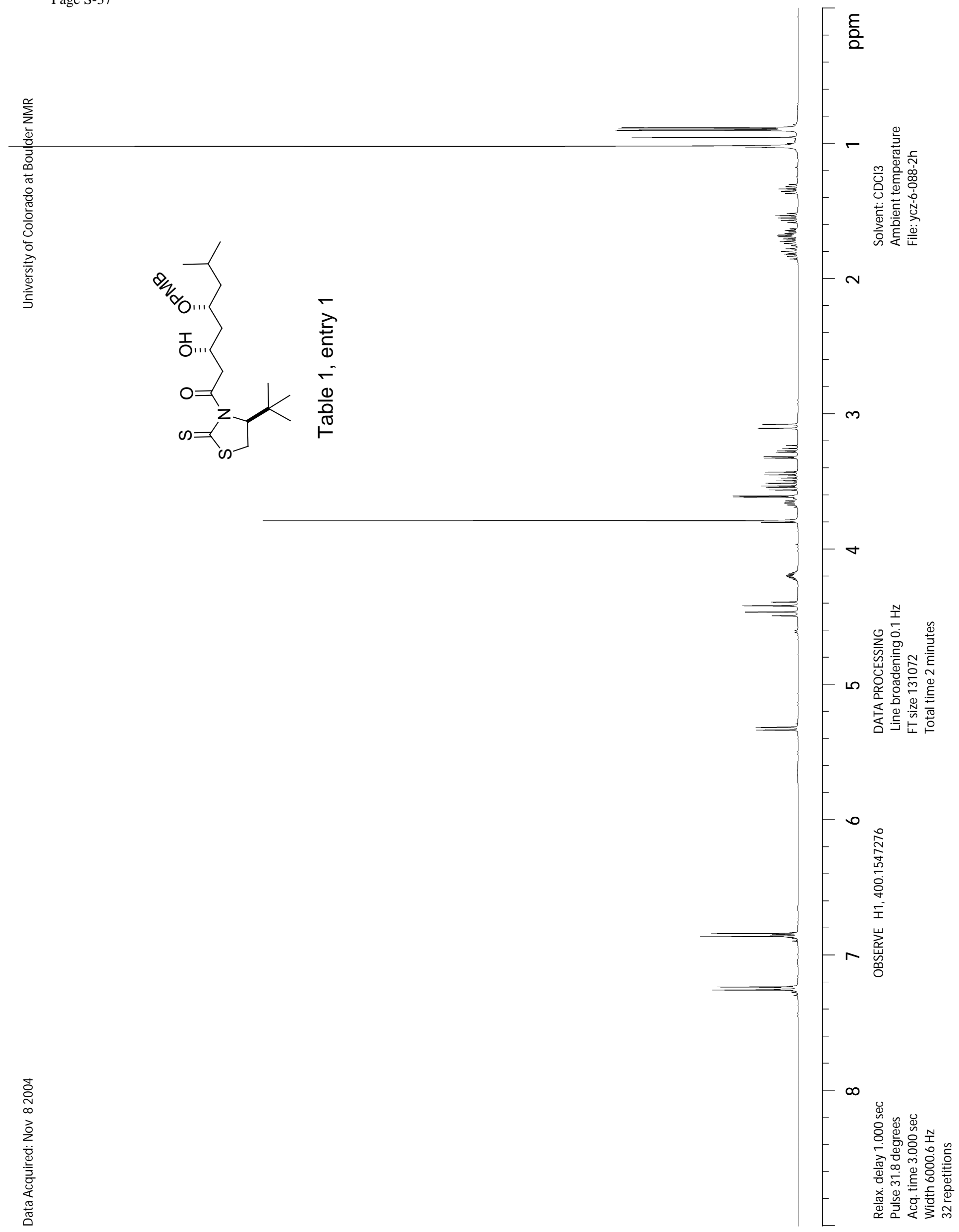




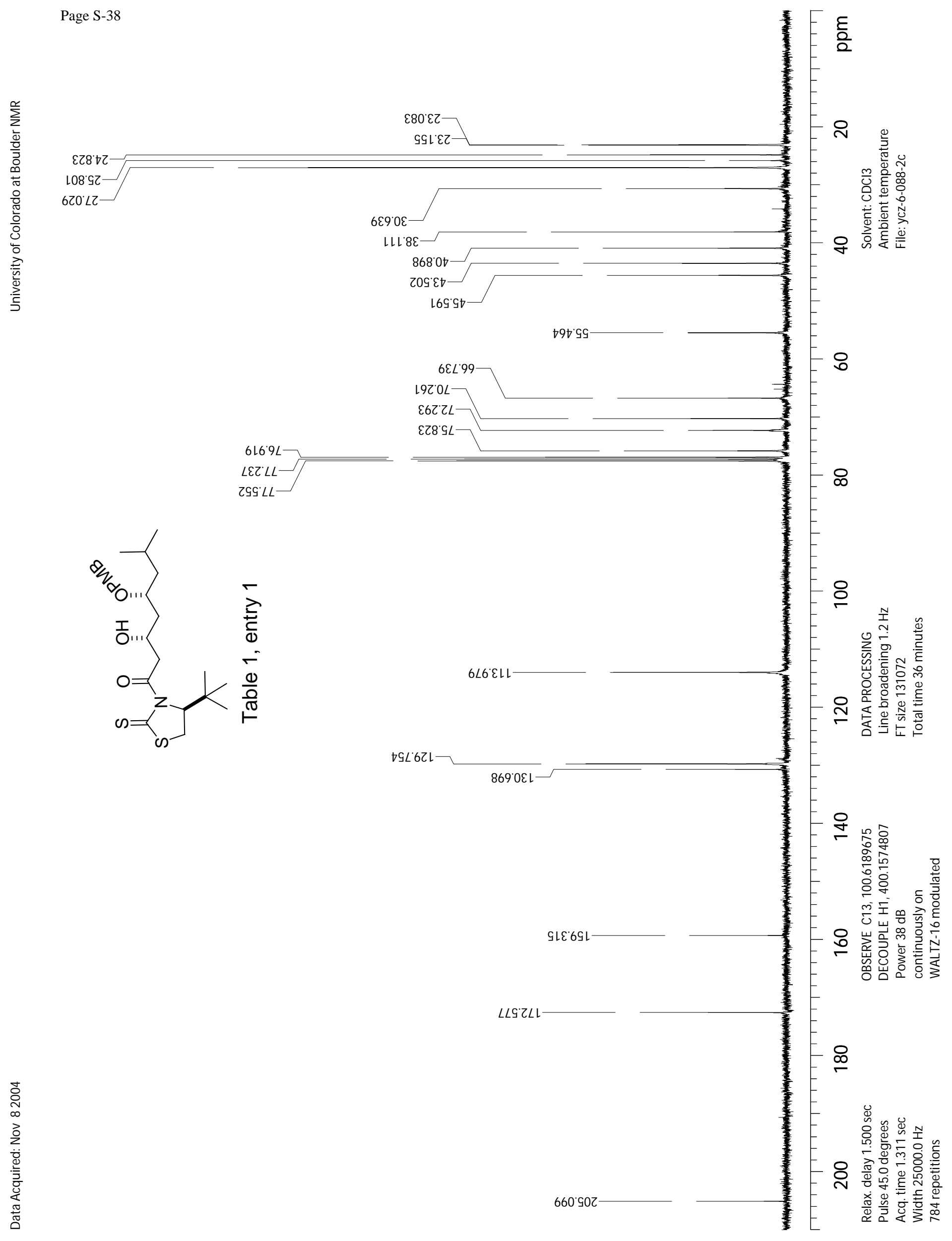


Page S-39

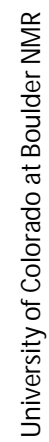
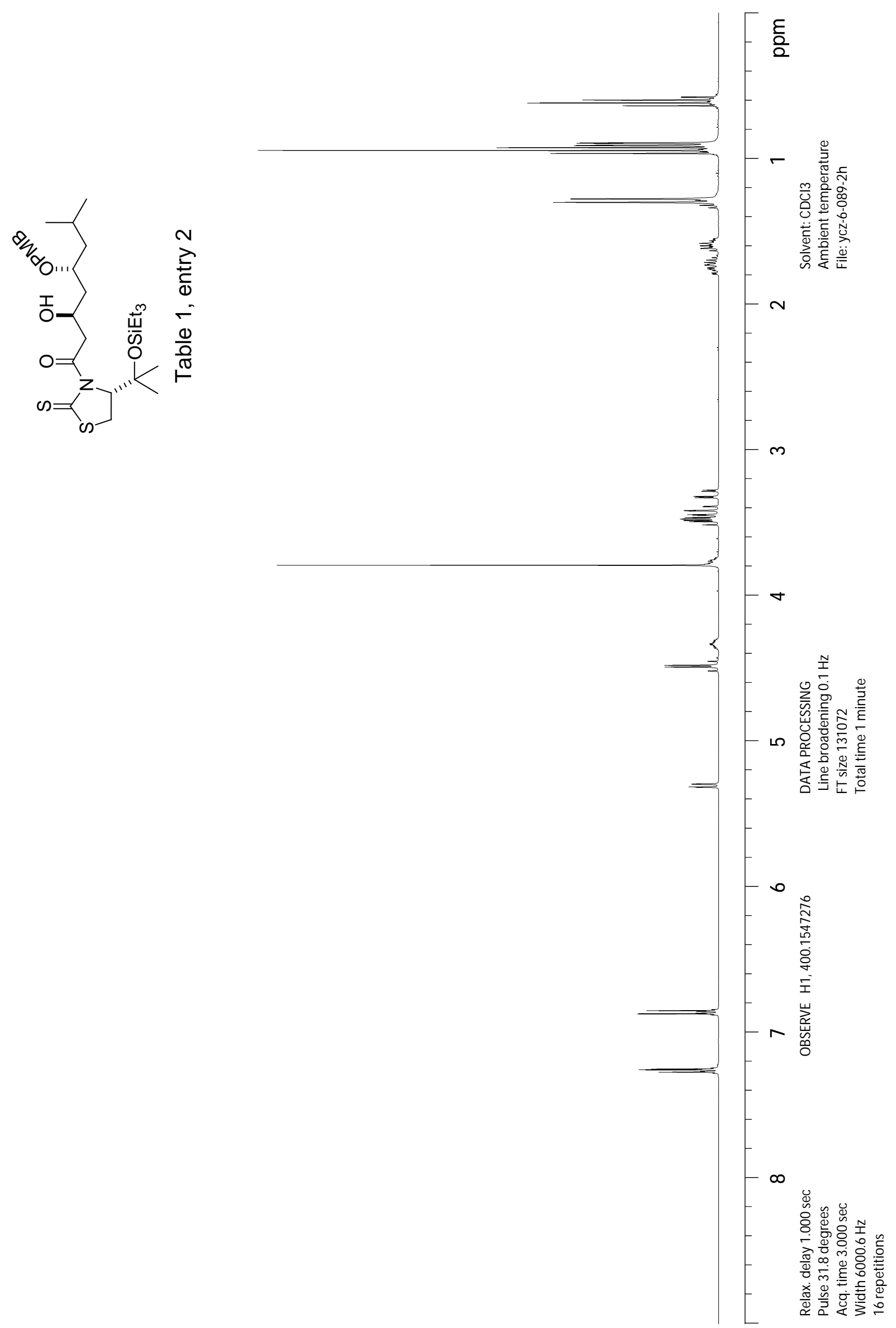
Page S-40

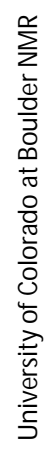

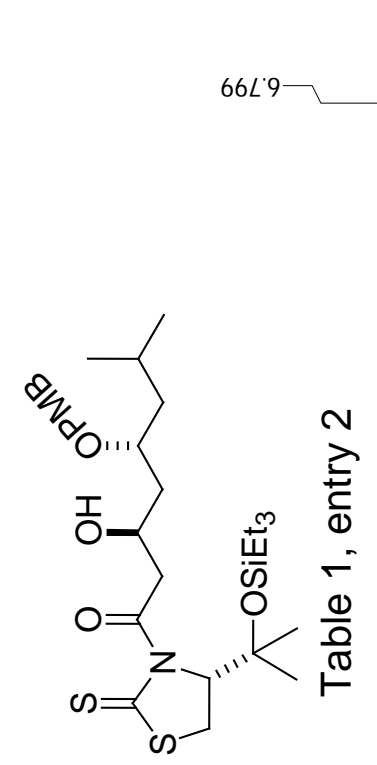

ع เ6. $9 L$ $L \varepsilon Z ' L L-$
$9 S S^{\circ} L L$

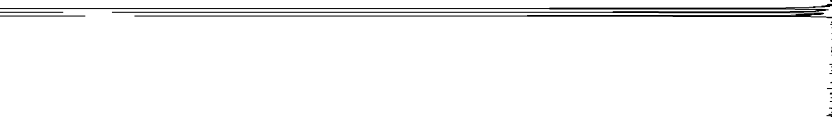

ه

8

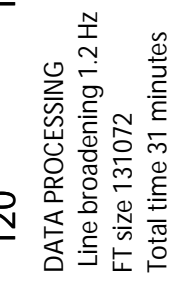

tZL'6ZI

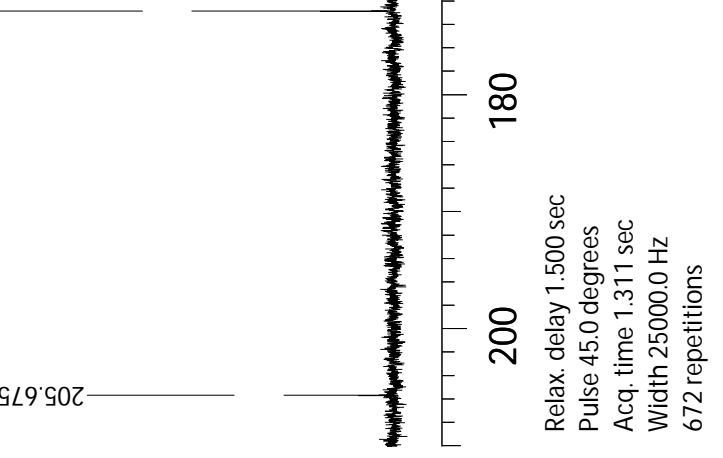


Page S-41

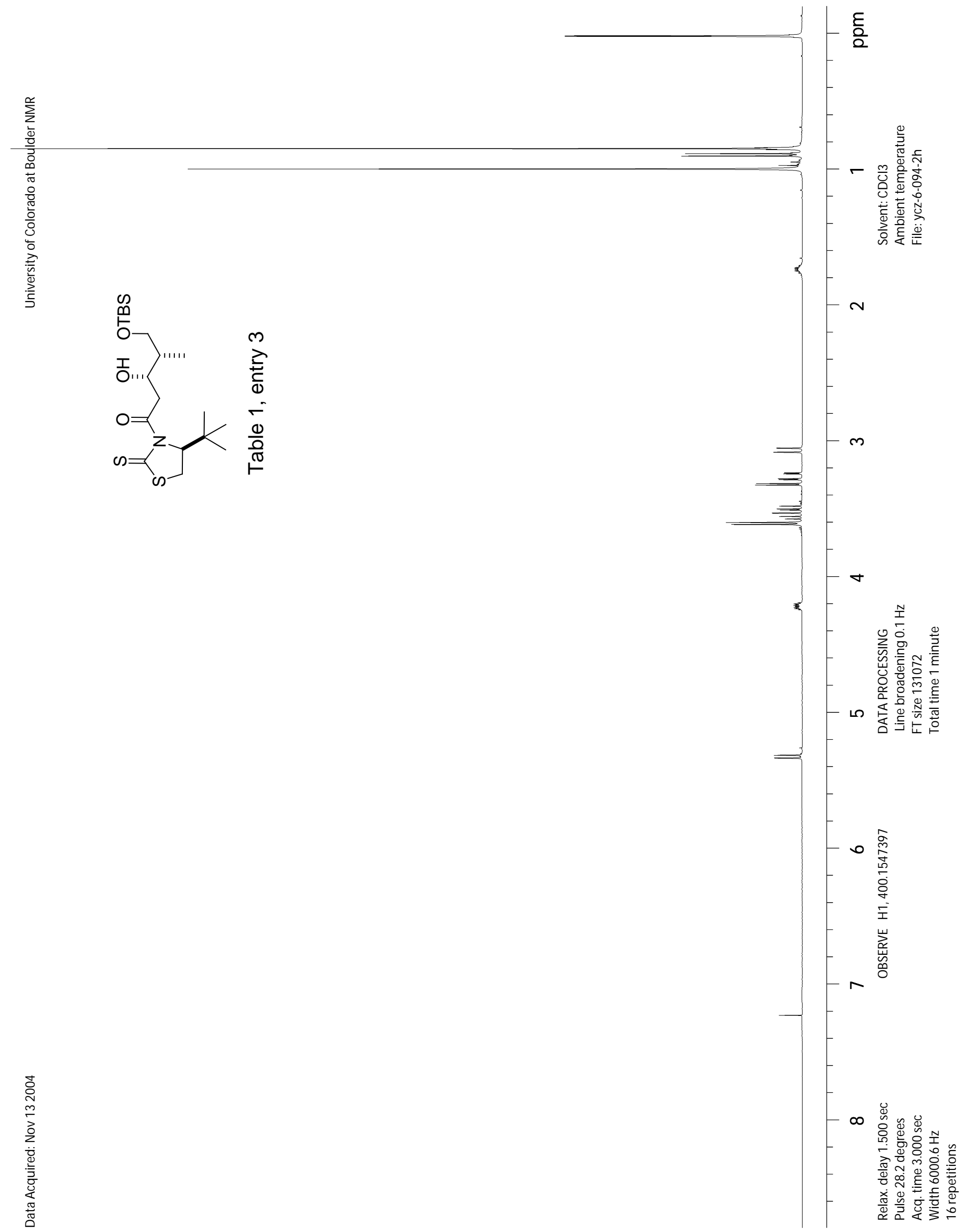


Page S-42

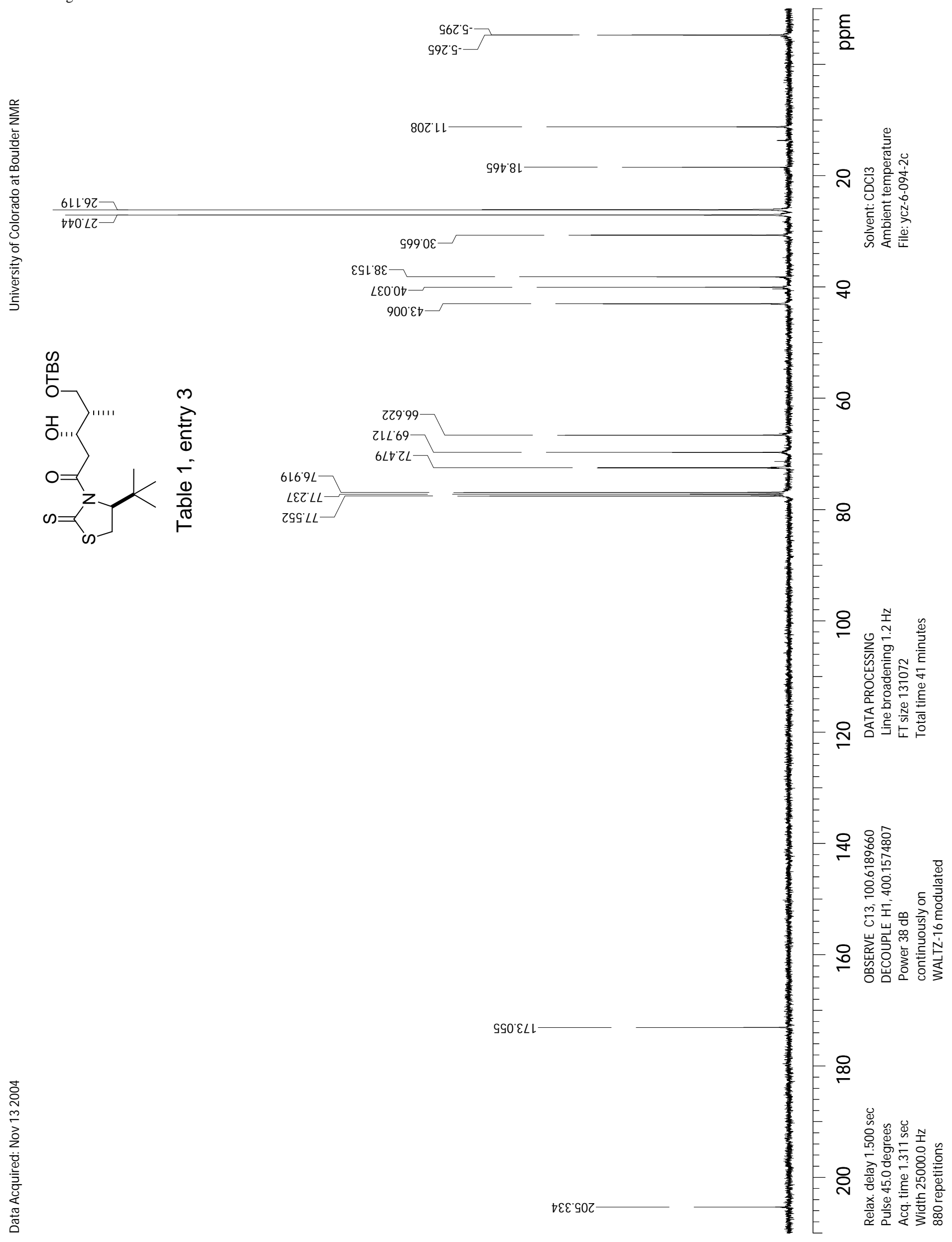




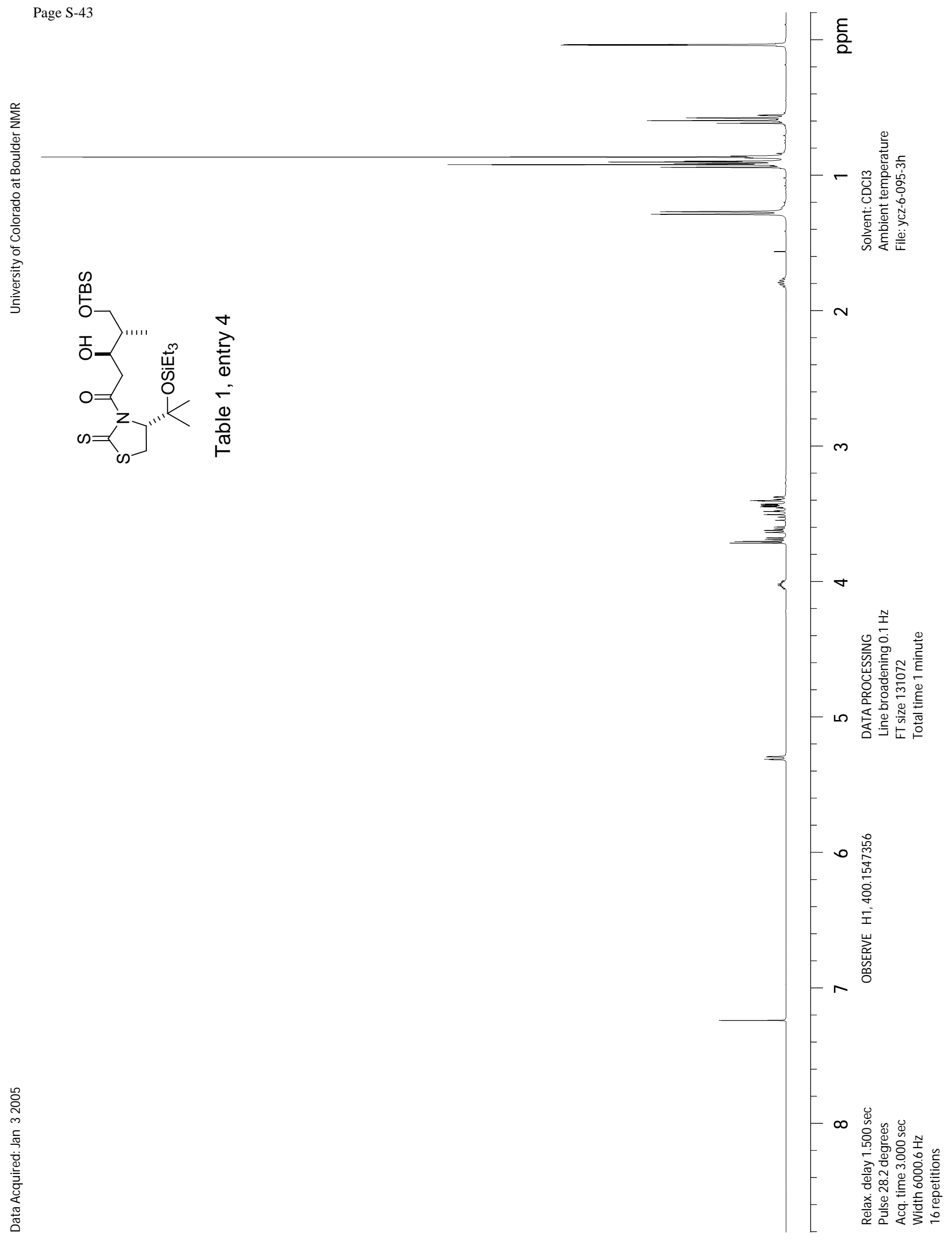


Page S-44

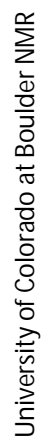
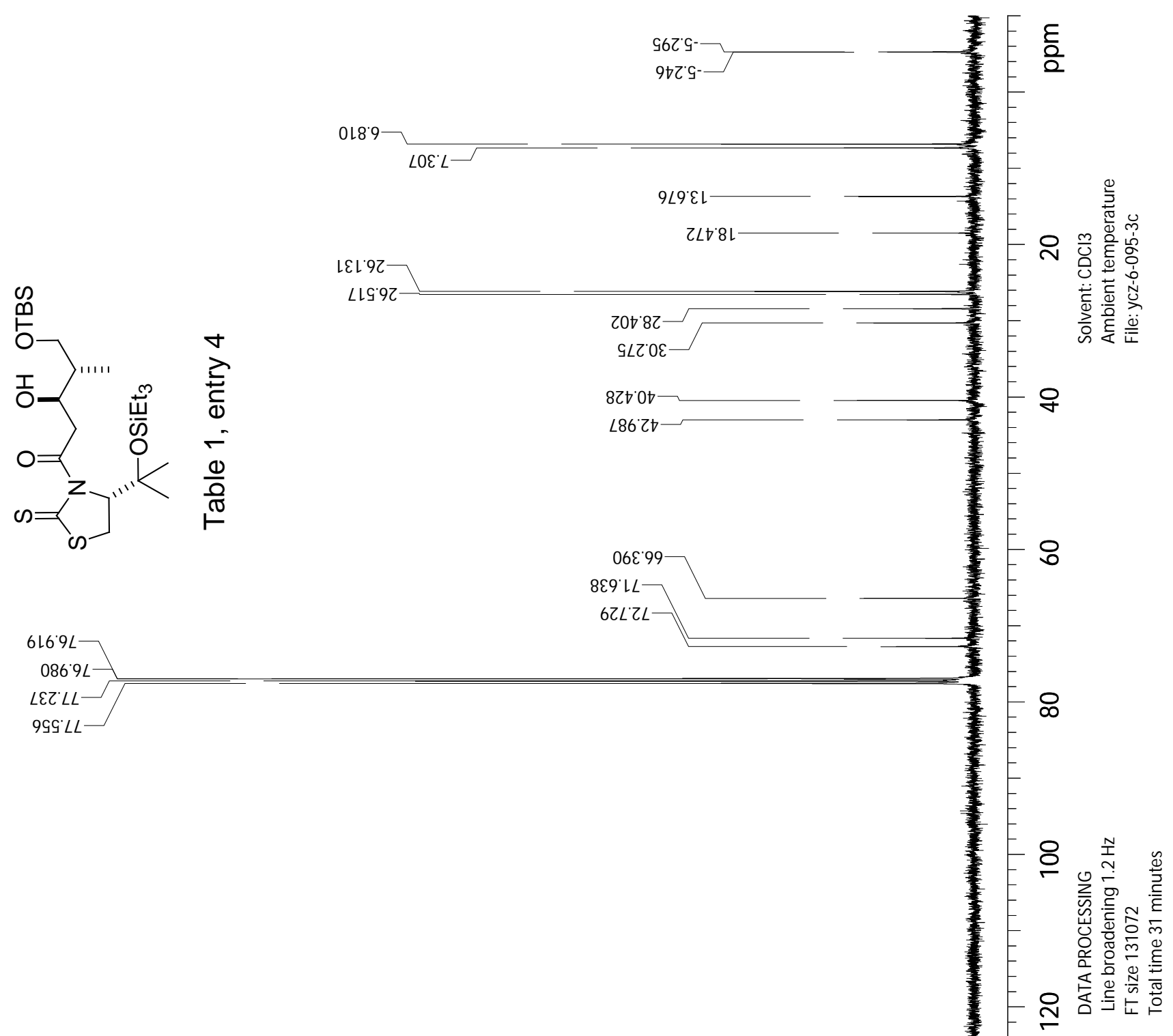

6I6.9L-

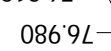

$\angle \varepsilon Z ' \angle L$ 9SS'LL-

임

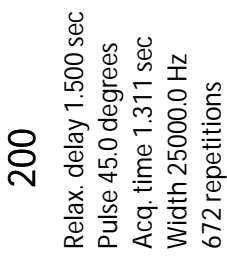


Page S-45

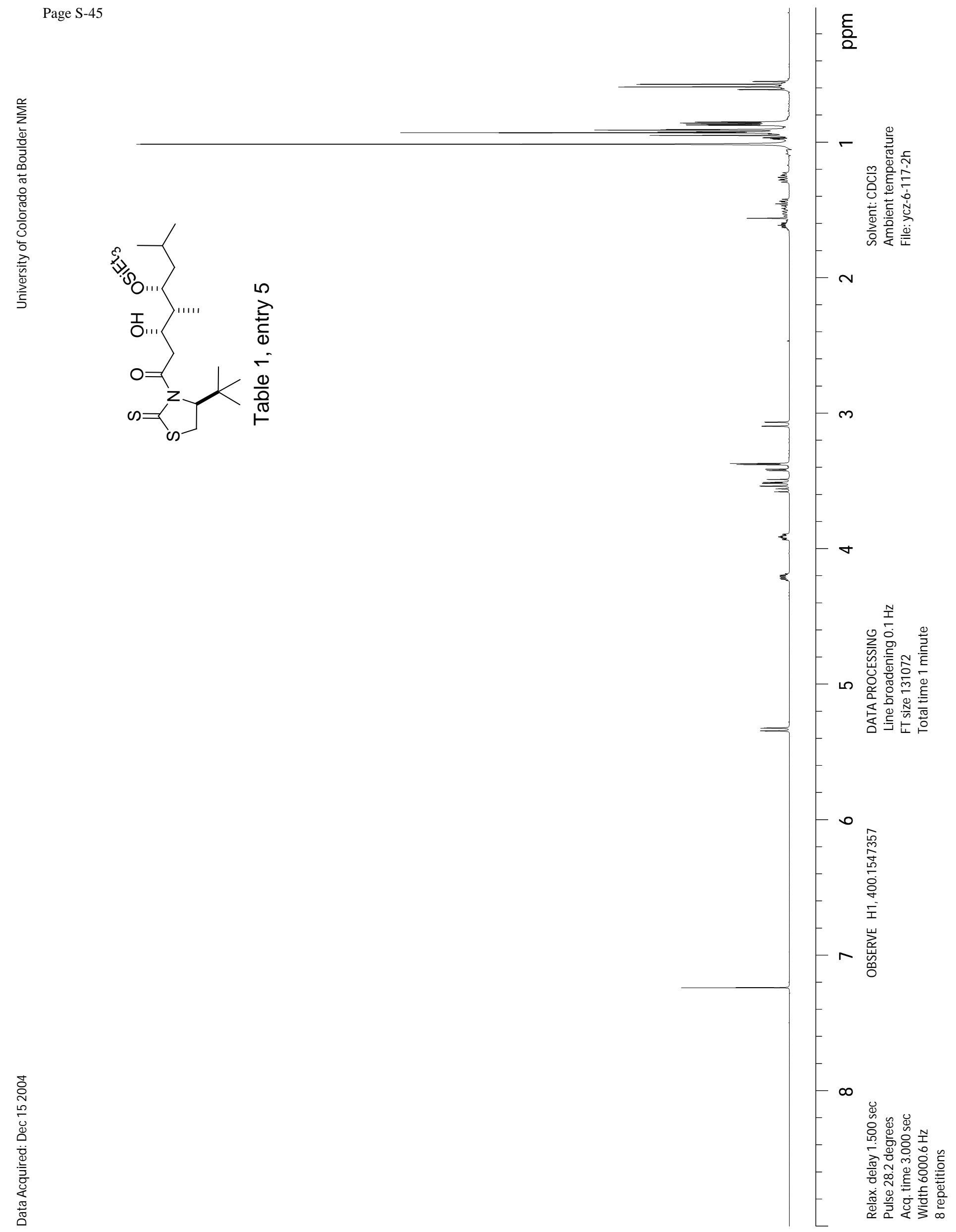


Page S-46
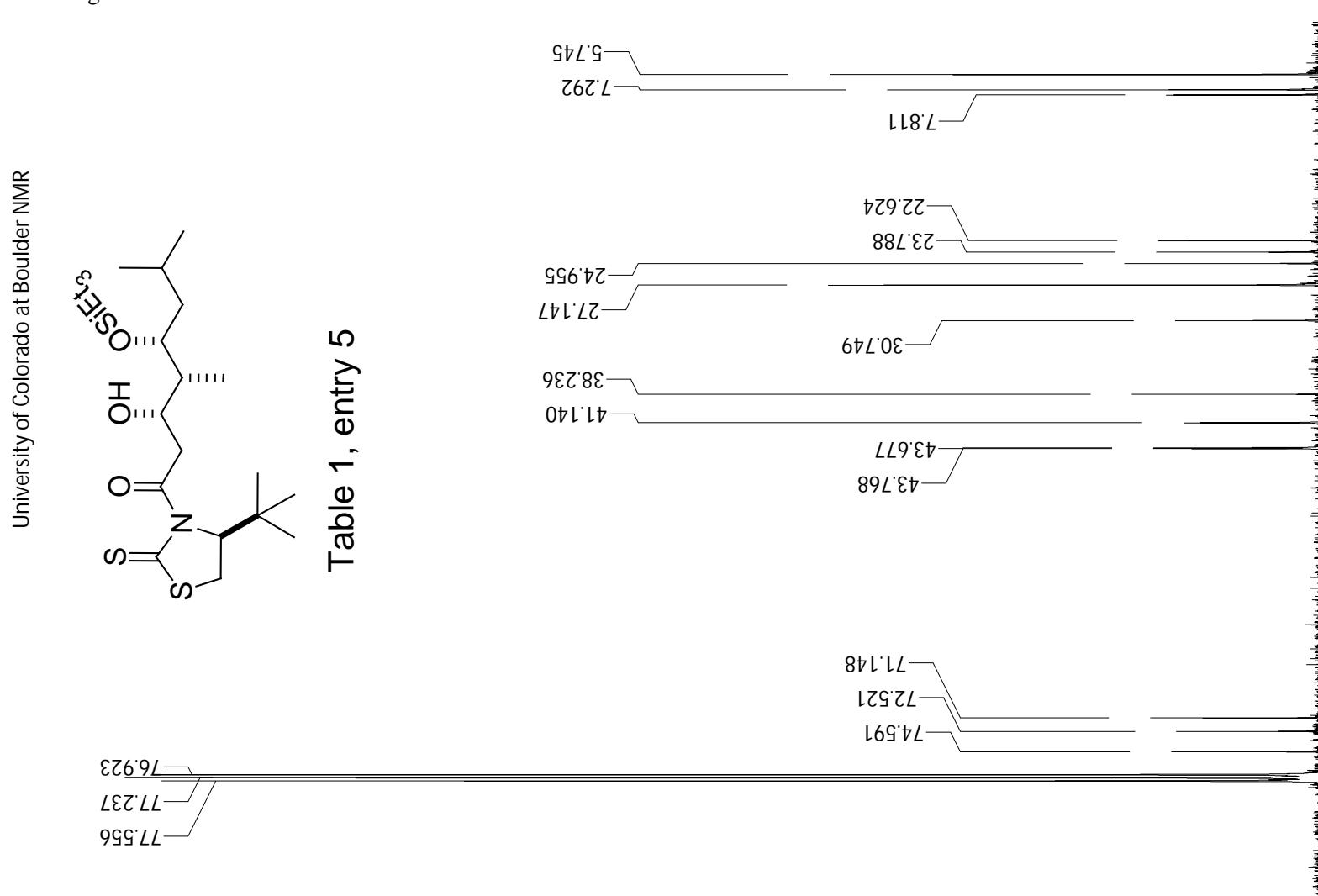

9SS'LL-
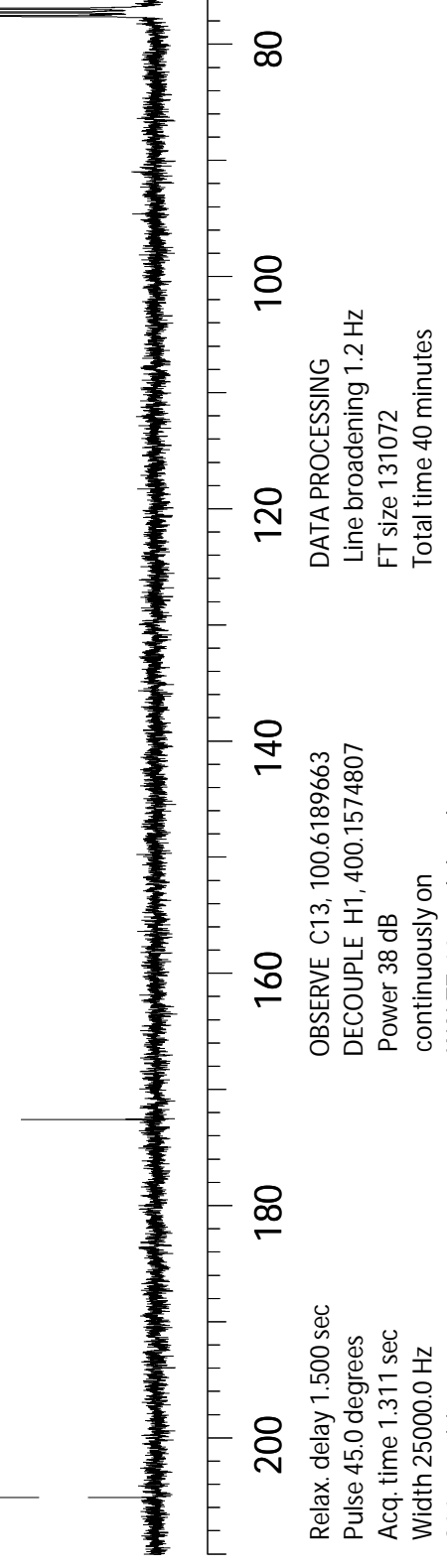

\&

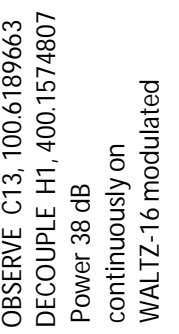

५9ৎ'ZLI

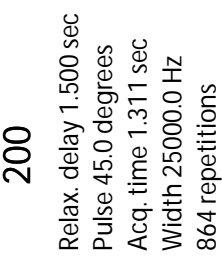


Page S-47

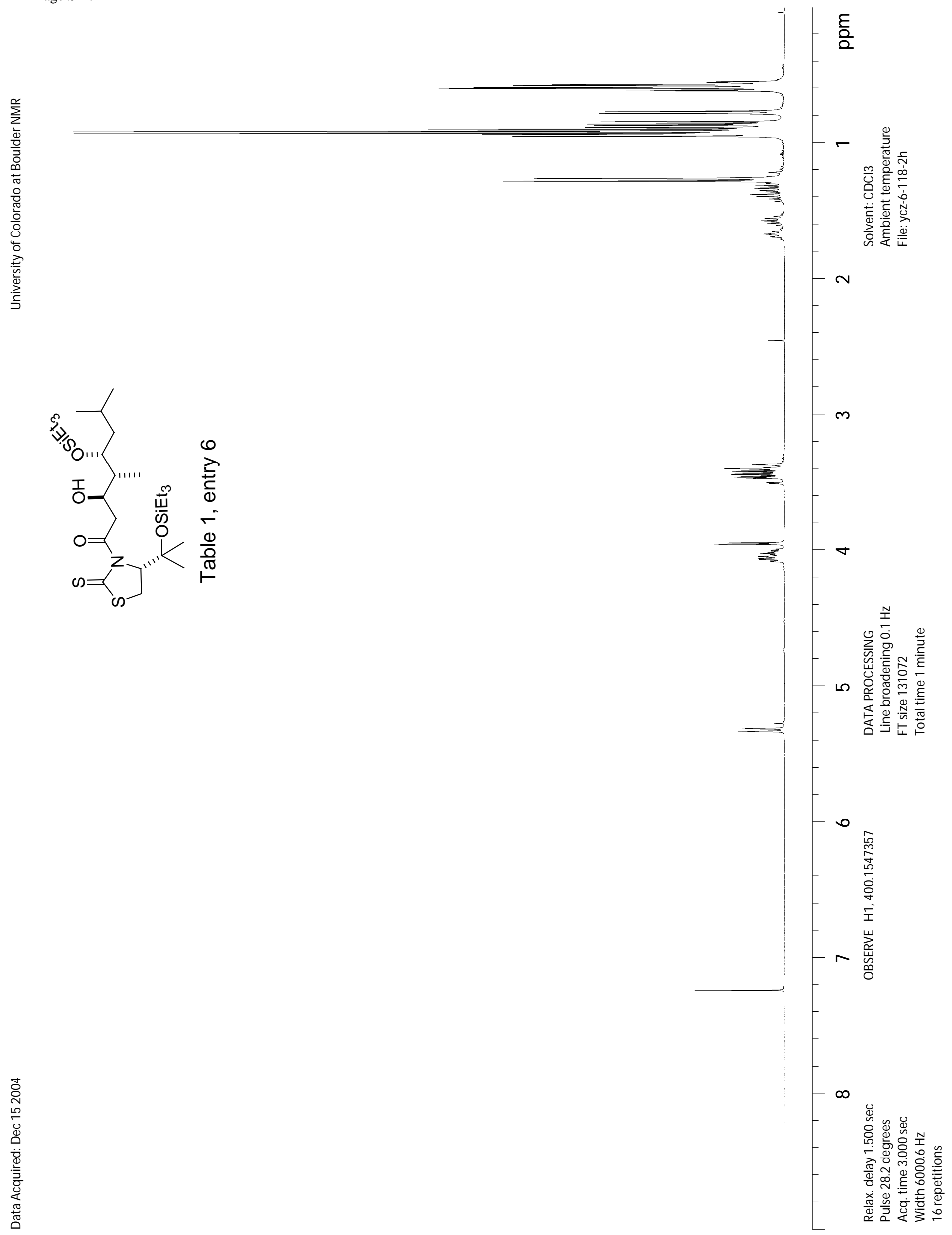




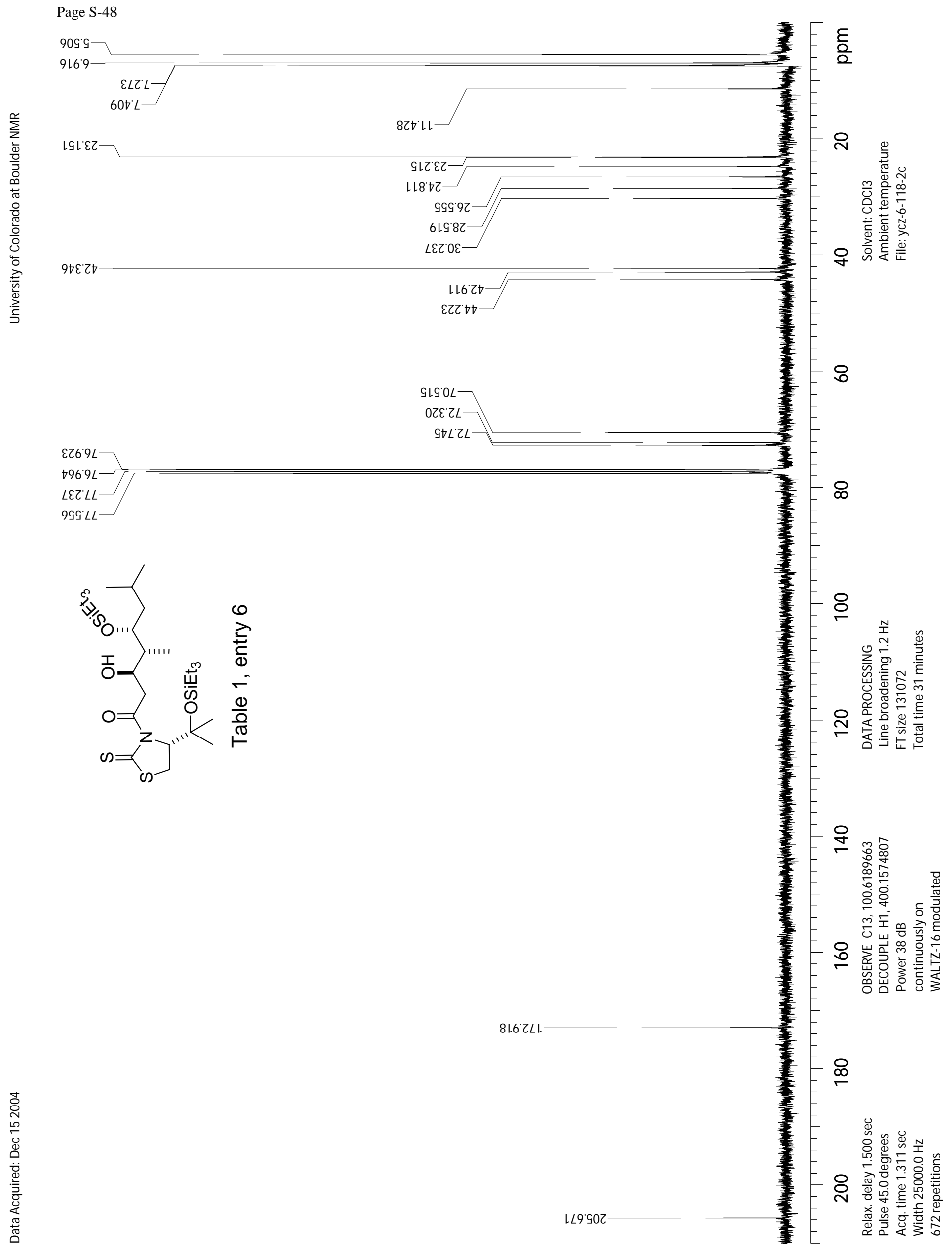


Page S-49

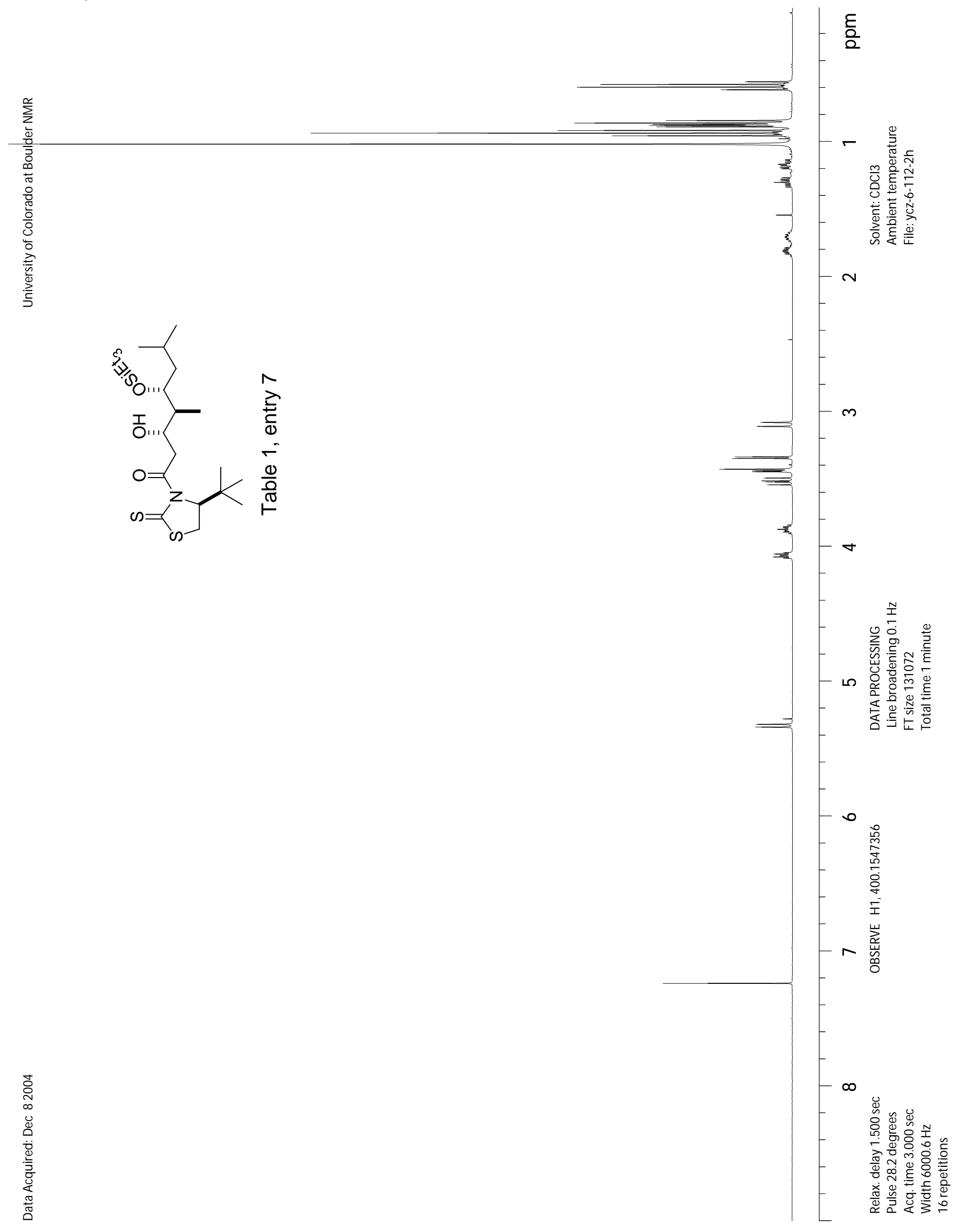


Page S-50

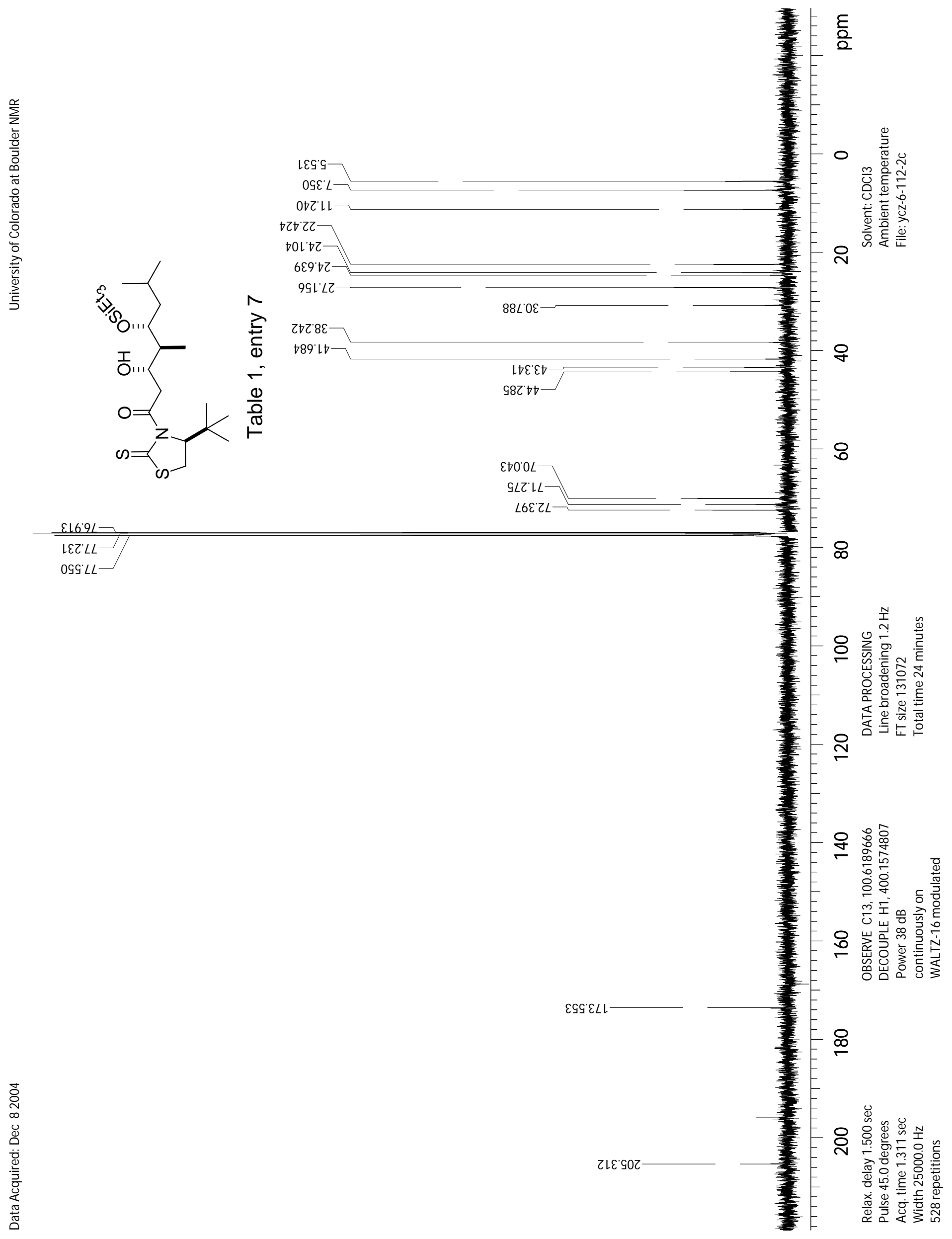


Page S-51

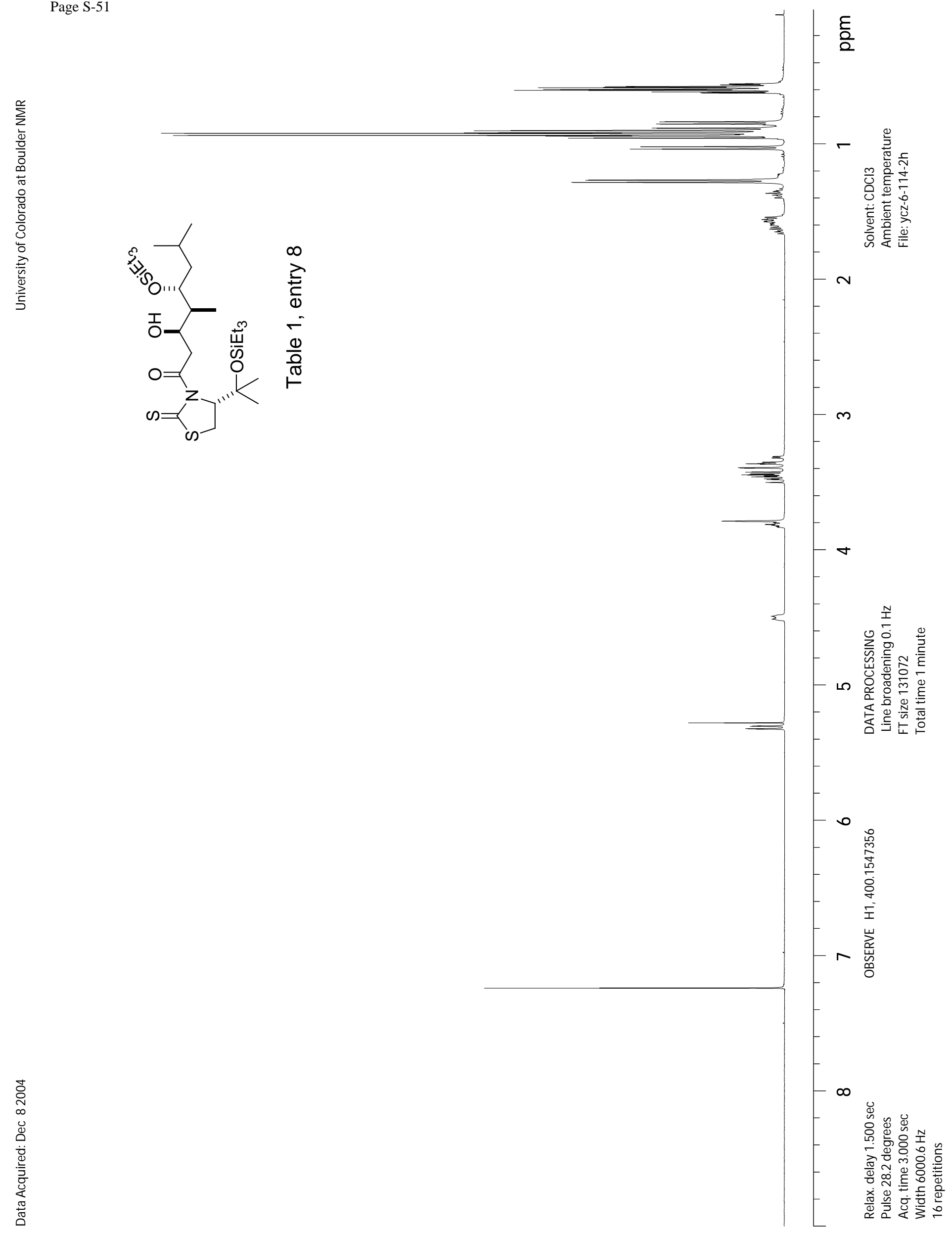


Page S-52

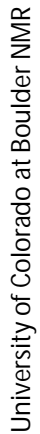

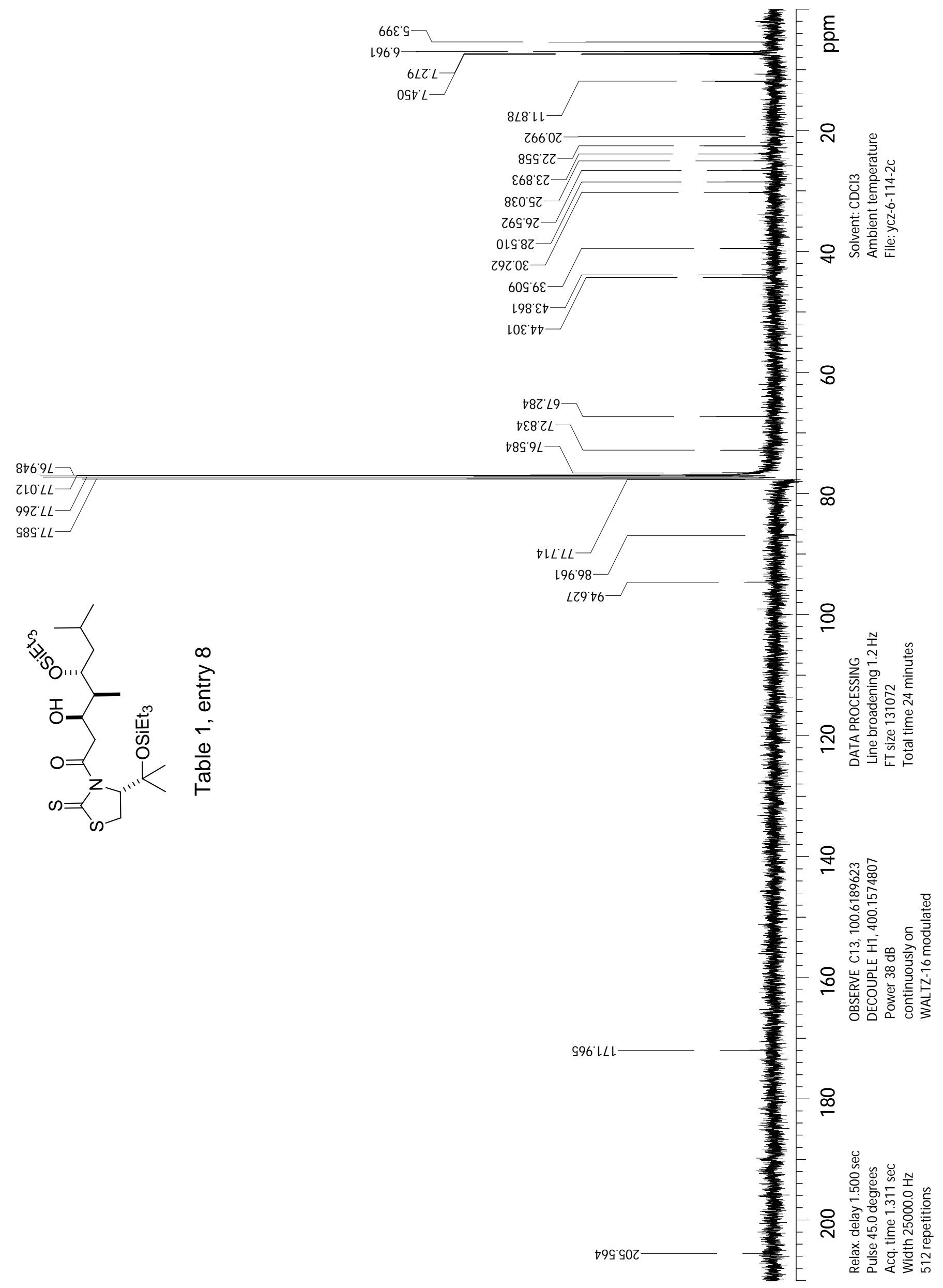


Page S-53

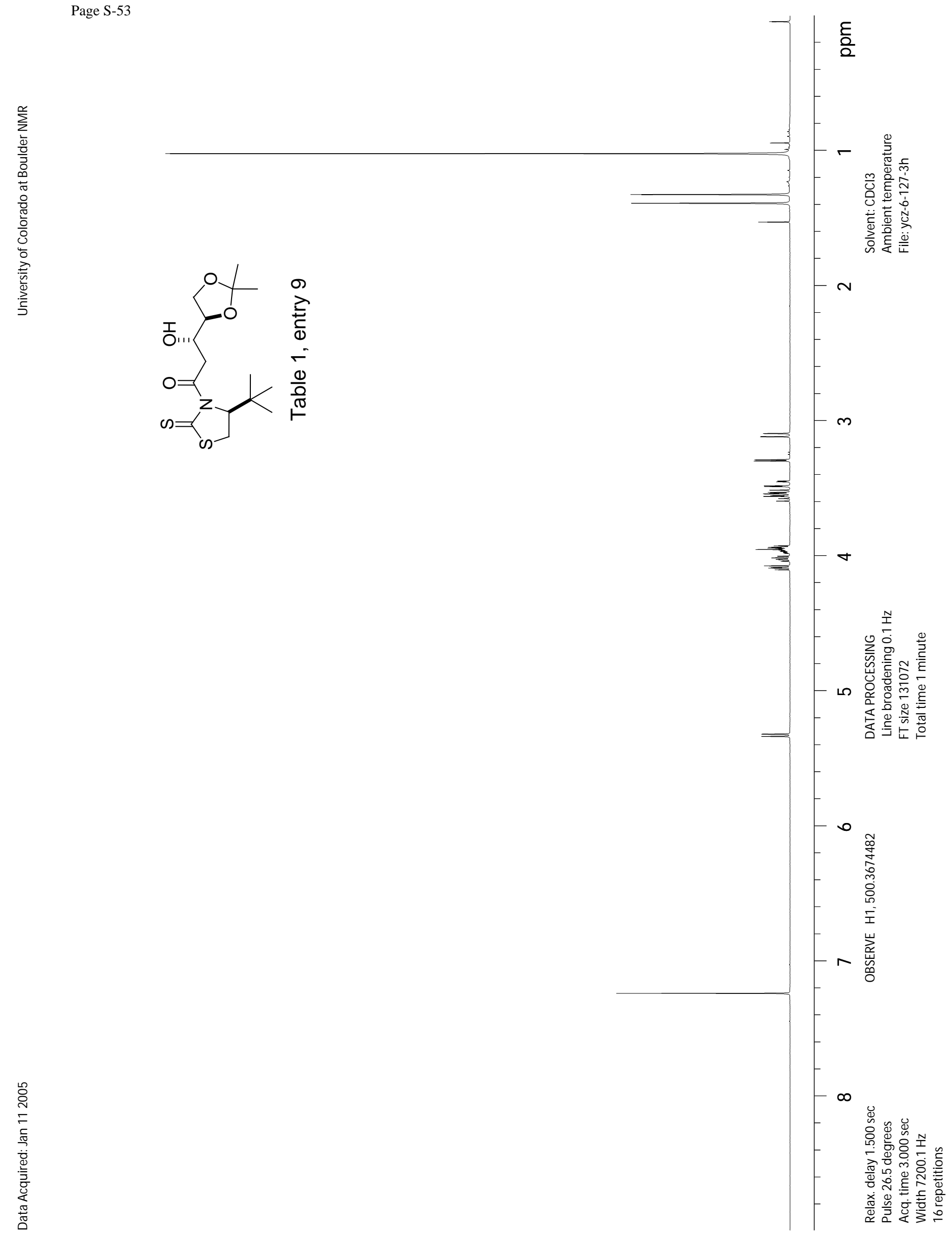


Page S-54

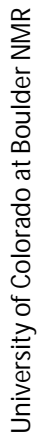

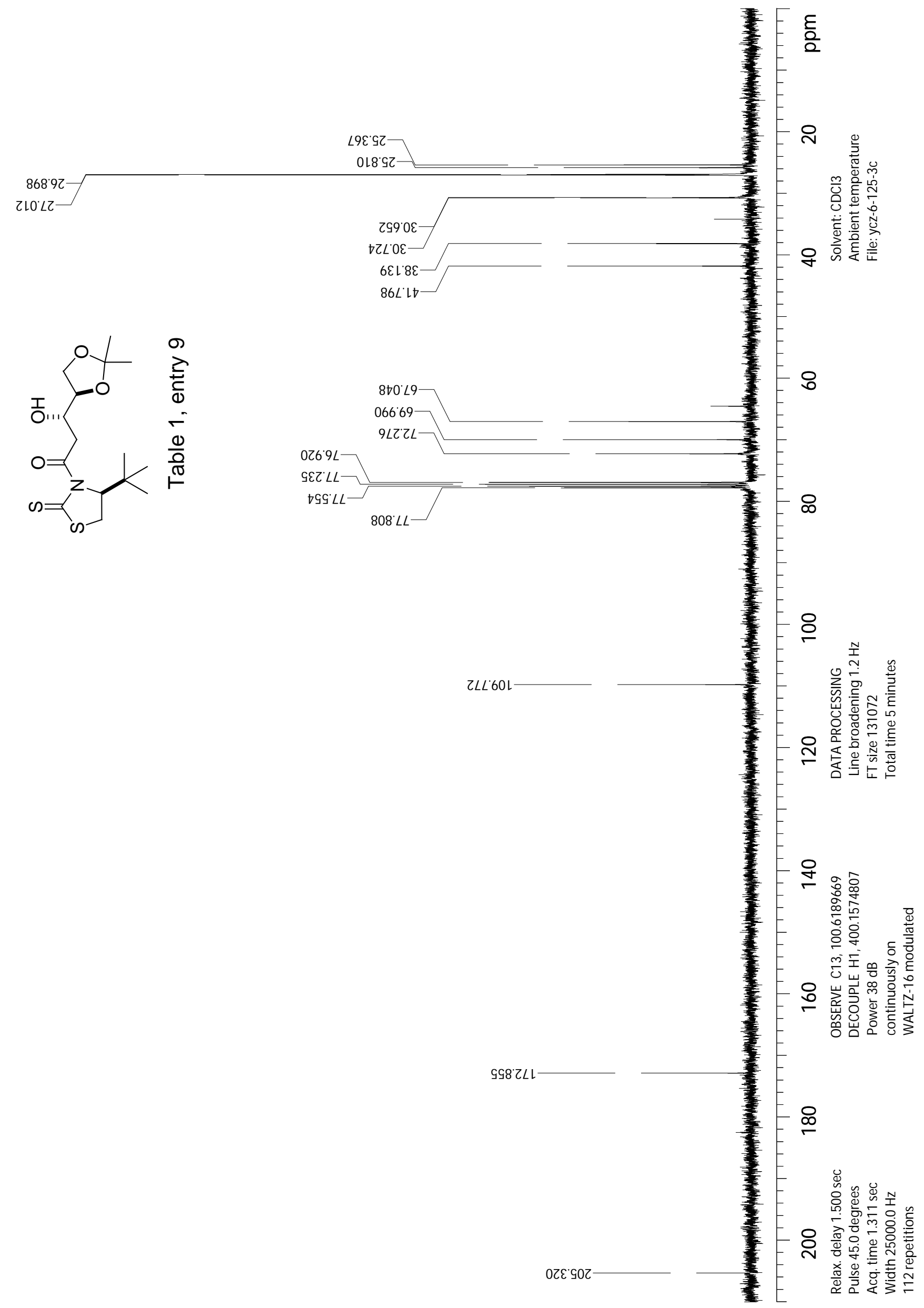


Page S-55

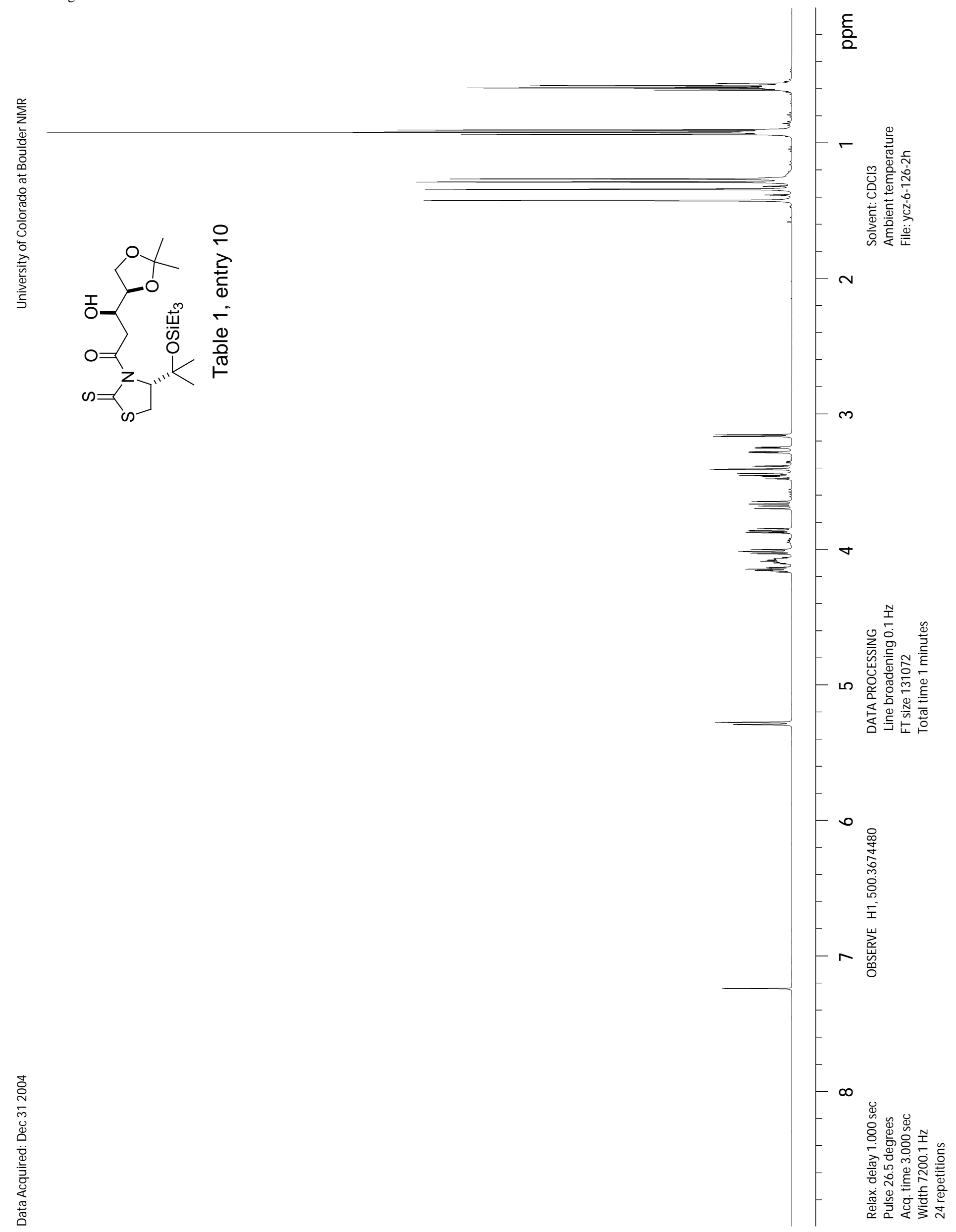


Page S-56

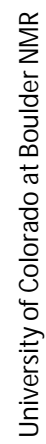

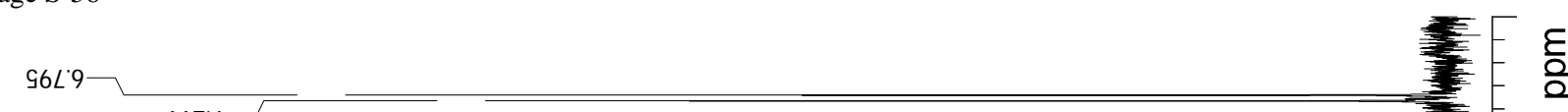

6โ6.9L

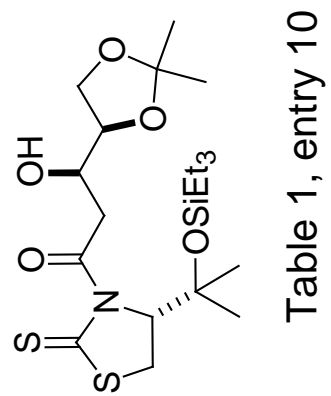
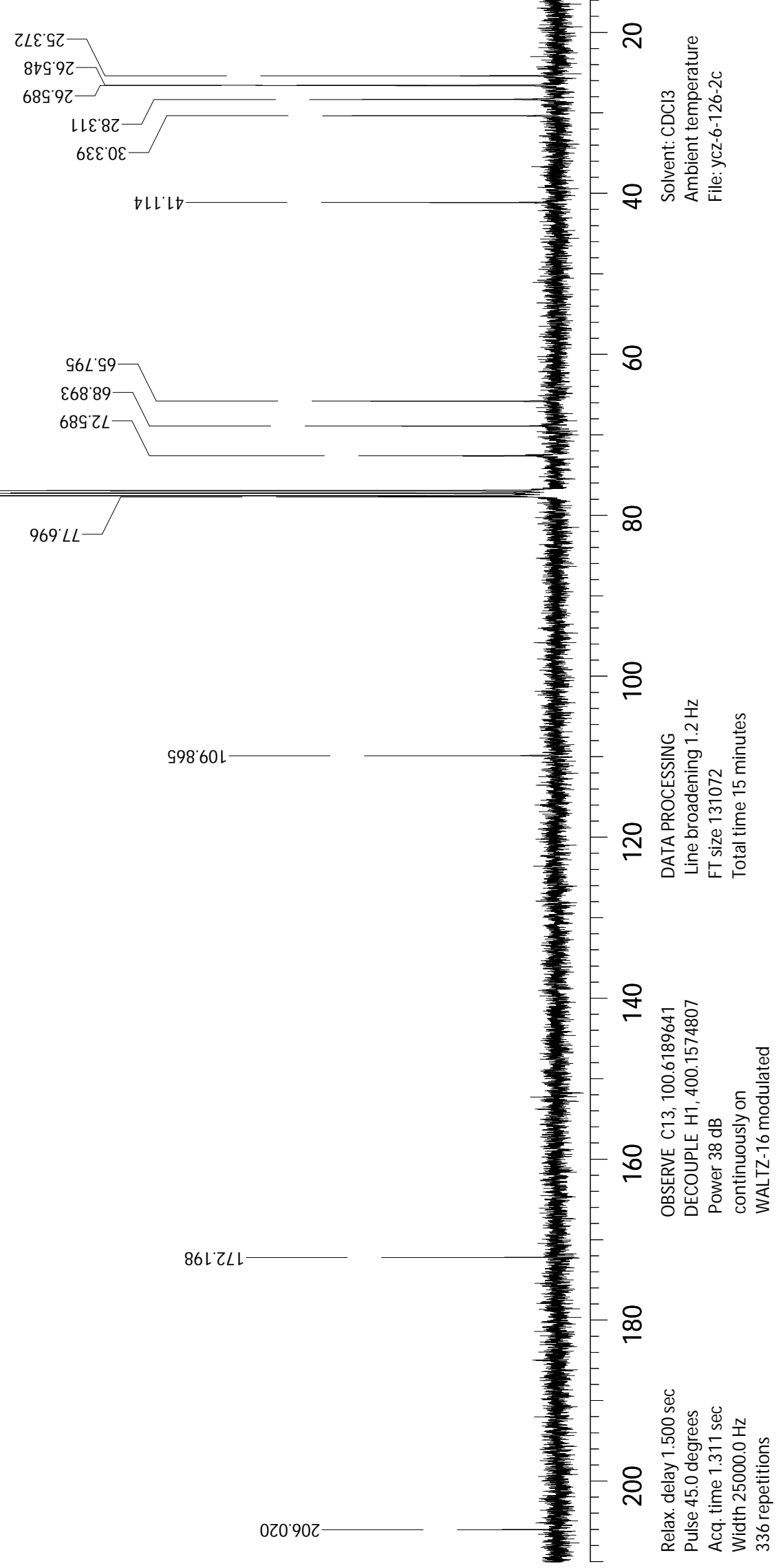